\title{
De-grading Assessment: Rejecting Rubrics in Favor of Authentic Analysis
}

\author{
Deborah L. Borman*
}

\begin{abstract}
Assigning grades is the least joyful duty of the law professor. In the current climate of legal education, law professors struggle with issues such as increased class size, providing "practice-ready" graduates, streamlining assignments, and accountability in assessment. In an effort to ease the burden of grading written legal analyses, individual professors or law school writing programs or both may develop articulated rubrics to assess students' written work. Rubrics are classification tools that allow us to articulate our judgment of a written work. ${ }^{1}$ Rubrics may be as extensive as twenty categories and subcategories or may be limited to only a few criteria. By definition, rubrics require the development of rigid, standardized criteria that the student must fulfill to earn a certain number of points. Points earned in each section of the rubric are totaled to form the basis for the student's grade.

In assessing legal analyses according to a standardized rubric, however, many subtleties of structure or content and much of the creativity

* Visiting Assistant Professor, Seattle University School of Law. Author's note: I have more people to thank than a Best Actor winner at the Academy Awards: For this grant, thanks to LWI \& ALWD and everyone on the grant committee, and in particular Mary Adkins for mentoring and reading and Greg Johnson for saintly patience. Sue Provenzano for my title. For support, encouragement, humor, power boosting, and a productive writing retreat: Debra Austin. Kim Holst, for insisting that every single one of my talks are articles. To the ASU Writing Workshop for early vetting. Nantiya Ruan, who insisted I write. To my close-reader: Susie Salmon. For research assistance Tom Gaylord, Northwestern Pritzker Faculty Services and Scholarly Communications Librarian, and the Pritzker Fellowship program, along with Evan Bianchi (Northwestern 2017), Connor Burke (Northwestern 2015), Aaron Kacel (Northwestern 2016), and Joshua Yim (Northwestern 2019); and Sharon K. Bäden and Alexandra Haller, Cleveland-Marshall College of Law. For tabulating the survey and for friendship: Michael Cooper. For physical therapy and Jane the Virgin wrap-ups: Karen Baumann. To my friends, the LWI community, and in particular: Coleen Barger, Karin Mika, Andrea Funk, Lucy Jewel, Catherine Wasson, and Cathren Page. And finally, for blindfolding me and teaching me to type on a manual typewriter in the basement of my Evanston home, and for encouraging independent, creative thinking and expression forever, my dad.

1. Eric D. Turley \& Chris W. Gallagher, On the Uses of Rubrics: Reframing the Great Rubric Debate, 97 ENG. J. 87, 89 (2008).
\end{abstract}


of legal writing is lost or unrewarded or both. Using a rubric to assess legal analytical writing may result in the exact opposite of the intended result: an excellent and creatively written persuasive brief or legal analytical argument may "fail" the rubric and earn a lower overall grade, while a legal analysis that fulfills the exacting criteria of the rubric may earn a top grade despite lacking the intangible aspects of excellent persuasive writing.

Good writing does not result when locked into the matrix of a rubric. Rubrics may impair writing and result in bad legal analytical writing. Rubrics replace the authentic, holistic analysis of writing and reasoning with inauthentic pigeonholing that "stamps standardization" onto a creative and analytical, that is, nonstandard, process. A holistic approach to grading and evaluating legal analytical writing, including engaging in authentic conversations about writing, leads to more comprehensible written work product and ultimately better lawyering.

\section{INTRODUCTION}

"By accepting the standardized responses inherent in rubrics, we undermine the power of the experiences of reading and writing ... assessment must be a conversation-just as writing exists for the purpose of conversation." -Maja Wilson ${ }^{2}$

While traveling a few years ago, I met a high school English teacher from my hometown. ${ }^{3}$ We talked about grading written work and immediately communed about the difficulty of using rubrics in the assessment of writing. The English teacher referred me to the writings of Maja Wilson, who advocates compellingly against the use of rubrics to assess essay writing at every level of education. ${ }^{4}$ Wilson's theory about assessment of essay writing is equally applicable to assessment of legal analytical writing because good legal writing comprises the same substance as good essay writing: a logical organizational container or construct, a thesis, an argument, an explanation or proof, and a conclusion.

In assessing written legal analytical work, the professor's goal is to provide students with an assessment of their analytical reasoning and writing skills necessary to construct a legal analysis for an objective assignment, for a persuasive assignment, or for a law school exam.

2. Maja Wilson, Why I Won't Be Using Rubrics to Respond to Students' Writing, 96 ENG. J. 62 , 66 (2007).

3. Additional thanks to this unnamed English teacher from Evanston Township High School, Evanston, Illinois, and to my own ETHS English Teacher, Mary Emerson, who encouraged my writing and did not employ a rubric.

4. See generally Wilson, supra note 2. 
As experienced legal readers and professors, we use our instincts to provide general guidelines and comments on assignments. When we have the freedom to provide coaching and suggestions based on our experiences as legal writers and readers, we can provide specific feedback on both large-scale and small-scale organization and content, which will help students increase their skills in writing and analysis. Students develop a growth mindset ${ }^{5}$ as well as confidence that with practice, they will excel on law school exams and legal analytical communication.

When we use a rubric, however, our instincts and experience as legal analytical readers are inhibited, and our feedback is restricted. The typical table with boxes and abbreviated ranked factors, accompanied by points to assign to various aspects of the written assignment, provides neither an authentic assessment of legal reasoning or writing skills nor an adequate instruction to the student; "students need models, feedback, and opportunities to ask questions." "For the professor, rubrics take longer to use for evaluation, as we must toggle repeatedly between the written work and the score sheet to attempt to wedge a subjective, productive comment into the rigid requirements of a tiny box with an assigned number.

In addition, the new law student, not yet accustomed to the highly competitive law school atmosphere, will receive that number score as a label, potentially creating a fixed mindset within the student of categorization or failure, with the student automatically attaching that number to his or her psyche as representative of personal or professional ability. $^{7}$

In my experience working with current students, coaching admitted students, and teaching in academic success programs or law school courses, the more holistic the feedback on written legal analysis the better. When we explain in sentences, using demonstration and illustration, students improve legal analytical writing, build skills, and develop the internal confidence necessary to achieve success as a legal analytical

5. See generally Carol S. DWeCK, Mindset: The New Psychology of SuCCESS (updated ed. 2007). Students who embrace growth mindsets - the belief that they can learn more or become smarter if they work hard and persevere - may learn more, learn more quickly, and view challenges and failures as opportunities to improve their learning and skills: "In a fixed mindset, people believe their basic qualities, like their intelligence or talent, are simply fixed traits. They spend their time documenting their intelligence or talent instead of developing them. They also believe that talent alone creates success - without effort." Carol Dweck, What Is Mindset?, MiNDSET, http://mindsetonline. com/whatisit/about/index.html [https://perma.cc/R9CD-XQHB]. Alternatively, "[i]n a growth mindset, people believe that their most basic abilities can be developed through dedication and hard work - brains and talent are just the starting point. This view creates a love of learning and a resilience that is essential for great accomplishment." $I d$.

6. Heidi Goodrich Andrade, Teaching with Rubrics: The Good, the Bad, and the Ugly, $53 \mathrm{C}$. TEACHING 27, 29 (2005).

7. See infra Part I. 
communicator. Personal, narrative feedback encourages improvement. By removing numbers as evaluation, students can focus on the feedback rather than the score for improving analytical writing. As a result, holistic assessment provides a vital step in promoting a growth mindset ${ }^{8}$ for academic and professional success.

In this Article, I advocate to end the trend of using rubrics for assessment of legal analytical writing. ${ }^{9}$ Part I provides a history of the use of rubrics, as developed through the college admissions process and later integrated into the grading process, and explains how standardization in assessment in education is historically discriminatory. While there are some andragogical ${ }^{10}$ uses for rubrics, the potential for discriminatory application and the underlying discriminatory history further underscore the potential damaging effects of using rubrics.

Part II examines rubrics typically used in teaching at all levels of education to evaluate analytical writing. As demonstrated, rubrics fail to promote either good learning or good writing. At the legal education level, law schools misconstrue the requirements of American Bar Association (ABA) curriculum standards by using rubrics to implement outcome assessment. The various standards for outcome and assessment cannot be fulfilled without implementing holistic evaluation. This Part incorporates the results of my rubrics survey of law professors who assign and evaluate legal analytical writing. I also discuss the effects of grading on student learning vis-à-vis rubrics.

Part III concludes with a recommendation against the use of detailed rubrics in assessment of legal analytical writing and provides suggestions for best practices in holistic evaluation.

\section{RUBRICS: A HISTORY OF DISCRIMINATION}

The history of rubrics is the history of barriers to entry to education. Legal education teaching methods are informed by education theory and practice used at the primary, secondary, and post-secondary education levels. ${ }^{11}$ Therefore, any discussion of assessment practices in legal

8. See generally DWECK, supra note 5.

9. I confine my thesis regarding the use of rubrics to written advocacy and other forms of persuasive legal analysis. Certain aspects of rubrics used in legal analytical courses that focus on organizing and articulating an elementary, objective legal analysis at the start of law study may be helpful.

10. Andragogy is the art and science of adult learning; thus, andragogy refers to any form of adult learning. See generally MALCOLM KNOWLES, THE Adult LEARNER: A NEGLECTED SPECIES (3d ed. 1984).

11. Anthony S. Niedwiecki, Lawyers and Learning: A Metacognitive Approach to Legal Education, 13 WIDENER L. REV. 33, 35 (2006). By analogy, for discussion regarding a dearth of learning theory knowledge and practice in elementary, secondary, college, and law education, see $i d$. at 36 . 
analytical writing education necessitates exploring the history of admission and placement practices by U.S. colleges, and of assessment of grades in primary, secondary, and higher education.

The theory and practice of assessing students' writing ability in primary, secondary, and higher education in the United States is grounded in exclusionary, artificial selection practices. College admissions and classification of students according to their abilities historically trends toward a "natural selection." 12 Rubrics are conveniently used in the selection processes, advancing and standardizing the selection and assessment process over the last one hundred years of education. This Part shows how the assessment of analytical writing in law education has shifted more than 100 years backwards to turn-of-the-twentieth century standardized writing assessment methods, closely following the trend in lower education. ${ }^{13}$

\section{A. Assessment by Social Class: Barriers to Entry}

In the latter half of the eighteenth century and at the turn of the nineteenth century, criteria for college admission centered on the applicant's social class. ${ }^{14}$ The first college entrance exams were oral, comprising a recitation of Latin and Greek classics. Only the elite who had access to education applied to and attended college. ${ }^{15}$

Once admitted, college students were organized and evaluated with an eye toward standing and social position. In Harvard's early years, student rosters were not arranged alphabetically. ${ }^{16}$ Instead, students were listed according to the social position of their families. ${ }^{17}$ At Yale, the classification used to differentiate student performance was made up of descriptive adjectives. ${ }^{18}$ Yale President Ezra Stiles described the very first grades assigned to fifty-eight students after a particular examination as follows: "Twenty Optimi, sixteen second Optimi, 12 Inferiores (Boni), ten Pejores." "19 The College of William \& Mary also classified and evaluated students with subjective descriptions in 1813: "No. 1 (Names listed) The first in their respective classes; No. 2. Orderly, correct, and

12. See generally Mark W. Durm, An A is Not an A Is Not an A: A History of Grading, 57 EDUC. F. 294 (1993).

13. See infra Part I.

14. Durm, supra note 12, at 296.

15. See generally Marvin Lazerson, The College Board and American Educational History, in A Faithful Mirror: Reflections on the College BoArd and EduCATion in America 379, 384-90 (Michael C. Johanek ed., 2001).

16. Durm, supra note 12, at 294.

17. Id. (citation omitted).

18. $I d$. at 295 (citation omitted).

19. Id. (citation omitted). 
attentive; No. 3. They have made very little improvement; No. 4. They have learned little to nothing." 20

As the industrial age advanced, the population of U.S. cities expanded. ${ }^{21}$ Immigrants looked to college as an opportunity to become marketable for jobs. ${ }^{22}$ At this time, Ivy League and otherwise estimable universities, such as the University of Michigan, began to employ essaywriting assessments to rank applicants according to their "ability to analyze a complex body of facts." 23 In reality, these writing assessments evaluated applicants' abilities based on their wealth and privilege, testing subjects such as classical languages or knowledge of ancient geography. ${ }^{24}$ The universities designed writing assessments to test certain subjects known only by well-heeled applicants. ${ }^{25}$ The unstated goal of these "standardized" essay-writing assessments was to exclude from admission immigrants who attended public schools. ${ }^{26}$ To that end, in 1874, Harvard released a fixed list of authors detailing whose work applicants would be expected to write about as part of the admission process. ${ }^{27}$ All authors were British and almost all were male. ${ }^{28}$

20. Id. (citation omitted).

21. Maja Wilson, Rethinking Rubrics In Writing Assessment 13-14 (Gloria Pipkin ed., 2006).

22. Id.

23. Id. at $14-15$.

24. See Alison Leigh Cowen, Remembering When Choosing a College Was a Buyer's Bazaar, N.Y. TIMES (Apr. 1, 2011), http://query.nytimes.com/gst/fullpage.html?res=9C03E5DF1E3CF932A35757C0A9679D8B63. In the 1870s, applicants to Harvard were required to be able to write in Latin and Greek and demonstrate knowledge on "the whole of Virgil," Caesar's commentaries, and Felton's Greek Reader. Id.

25. Applicants were tested on ancient and modern geography, history, English, and mathematical topics. Id.; see also Julia Ryan, How Getting into College Became Such a Long, Frenzied, Competitive Process, ATLANTIC (Nov. 11, 2013), https://www.theatlantic.com/education/archive/2013/11/howgetting-into-college-became-such-a-long-frenzied-competitive-process/281336/.

26. See Arthur N. Applebee, Tradition and Reform in the Teaching of English: A HISTORY 6-8 (1974); see also VINCENT THOMPKINS, AMERICAN ERAS: DEVELOPMENT OF THE INDUSTRIAL UNITED STATES (1878-1899) 154-56 (1997). Immigrants to the United States in the late nineteenth century were likely to be illiterate, making them unlikely to meet the admissions requirements set forth supra. Instead, there was a rise in separate programs for "industrial training" or Technical and Professional schools. See supra at 155.

27. Edwin Cornelius Broome, A Historical and Critical Discussion of College ADMISSION REQUIREMENTS 58 (1903).

28. Id. Broome includes the following excerpt from the Harvard catalogue of 1873-1874: Each candidate will be required to write a short English Composition, correct in spelling, punctuation, grammar, and expression, the subject to be taken from such works of standard authors as shall be announced from time to time. The subject for 1874 will be taken from one of the following works: Shakespeare's Tempest, Julius Caesar, the Merchant of Venice; Goldsmith's Vicar of Wakefield; Scott's Ivanhoe, and Lay of the Last Minstrel. 


\section{B. Assessment Eugenics}

Rubrics were first used to assess essay writing in 1878, the year that A.S. Hill, Harvard's Boylston Professor of Rhetoric, advanced his "current traditionalist" pedagogy. ${ }^{29}$ The "current traditionalist" view provided that written discourse be delivered in a mechanical form and focus particularly on grammar. ${ }^{30}$ Hill created an American identity around a "properly used" English-language that rejected "classical" standards of taste. ${ }^{31}$

Employing the current traditionalist approach, a writing instructor corrected mechanical errors such as spelling, syntax, uniform style, and arrangement. ${ }^{32}$ The purpose of writing was "to make the patterns of arrangement and superficial correctness the main ends of writing instruction." ${ }^{33}$ Hill's The Principles of Rhetoric governed writing assessment from approximately 1878 to 1923 , but the theory and focus of current traditionalism influenced both the teaching and the assessment of writing in primary, secondary, and college classrooms until the 1960s. ${ }^{34}$

Hill's success in shifting the focus of the writing assessment away from form and substance and toward grammar provided Harvard and other universities the opportunity to convert written essay admissions tests into multiple-choice grammar tests complete with a scoring rubric. ${ }^{35}$ In 1912 , Milo B. Hillegas developed a rubric for evaluating written essays: a system of "composition scales." 36 The "Hillegas Scales" sought to rank students" writing without describing or defining what writing was subjectively "good." ${ }^{37}$ The Hillegas Scales purported to address claims of subjectivity in assessment and attempted to eliminate discriminatory practices. ${ }^{38}$ Composed of a group of pre-ranked example papers, "teachers would compare students' work to the papers on the scale, find the best match, and give the accompanying grade." 39

In theory, the Hillegas Scales permitted any educator anywhere to score the writing test in the same way in a short amount of time. ${ }^{40}$ The results of the tests could be easily grouped and categorized, and students

29. See generally AdAMS SHERMAN Hill, THE PRINCIPLES OF RHETORIC (1878).

30. See generally id.

31. See generally id.

32. See generally id.

33. JAMES A. BERLIN, RHETORIC AND REALITY: WRITING INSTRUCTION IN AMERICAN COLLEGES, 1900-1985, at 9 (1987).

34. See generally HILL, supra note 29; see also WILSON, supra note 21.

35. See generally HILL, supra note 29.

36. See generally Milo B. Hillegas, A Scale for the Measurement of QuAlity in ENGLish COMPOSITION BY YOUNG PEOPLE (1912)

37. Id.

38. $I d$.

39. Id.

40. Id. 
could be ranked both individually and by groups, ${ }^{41}$ thus serving the classification needs of academic institutions. ${ }^{42}$

Problems emerged with the Hillegas Scales, however, when teachers did not agree on the ultimate grade: "If a standardized scoring tool does not produce the same score when different people use it, it is hardly a standard." ${ }^{, 43}$ Teachers could not reliably rank written essays based on the scales, as described in this 1918 trial peer-review experiment:

The Hillegas scale was presented and each student provided with an exposition written by a fellow-student, which he was to grade. The task was undertaken with avidity. The next day a chastened class appeared. Difficulties were great. One said, "This composition would receive a very high mark by the scale, but it is not satisfactory at all, because the topic is not developed by the method assigned. I don't know what to do with it." Tied to the scale, their teacher was equally at a loss. The marks were considered and criticized until the class revolted, claiming inability to see the value of the whole performance. Except for some points to be indicated later, their teacher was again equally at a loss. Before the question was dropped, it was agreed that a mark on a composition was simply the teacher's approval or disapproval of the exercise. A good mark carried the conviction of the instructor that the point the lesson was designed to illustrate was made and that there was also a satisfactory handling of points previously made, as well as worthy content. The mark was worth just what the teacher's opinion was worth and could in the nature of things be worth nothing else. ${ }^{44}$

Moreover, the scales proved to inhibit individualized student learning, ${ }^{45}$ instead reinforcing artificially created stereotypes in assessment. "Writing to the Scales" ranked students to serve institutional needs, not student learning methods. ${ }^{47}$ In addition, students were forced to

41. Id.

42. WiLSON, supra note 21, at 19.

43. Id.

44. Flora E. Parker \& S.A. Courtis, The Value of Measurements: I. The Measurement of Composition in English Classes: II. The Uses of the Hillegas Scale, 8 ENG. J. 203, 205 (1919).

45. Id. at 208 ("But compositions can never, because of their nature, be measured with the accuracy used in measuring extension, weight, and time; it would be a calamity if they could. Every teacher worth the hire has an idea. The one aim is, again to quote loosely, the conversion of humans to that selected idea by the only way a thing can get to another-by a human, not by a machine-like, system.").

46. WILSON, supra note 21, at 19.

47. Id. As discussed in Part II, the overall effect of the standardized scoring tool on students was to enhance summative assessment and decrease metacognition, forcing students to memorize items for testing purposes rather than challenging students' cognitive processes. See infra Part II. 
focus on assembly and memorization of the "sum of the parts" rather than the whole of the subject matter. ${ }^{48}$

Despite problems regarding reliability of the scales and standardization in grading, educators tended to enjoy the ease of administering and scoring multiple-choice tests. ${ }^{49}$ Concurrently, colleges sought to devise their own assessment tools for admission. In 1899, Columbia University, along with a consortium of eleven other colleges and high school preparatory academies, founded the College Entrance Examination Board (College Board).$^{50}$ The College Board's stated mission was to "expand access to higher education" by pursuing standardization. ${ }^{51}$ The College Board ultimately settled on U.S. Army testing and assessment methods to fulfill its quest for standardization. ${ }^{52}$

When the United States entered into World War I in 1917, Robert Yerkes, psychologist and president of the American Psychological Association, offered his services to assist in screening Army recruits. ${ }^{53}$ Yerkes, a renowned pioneer in the study of both human and primate intelligence, was well-known for propagating his support for eugenics: the concept of selective breeding that sought to produce "better human beings." 54 Together with Yerkes, psychologist Carl Brigham developed and administered psychological tests known as "Alpha" and "Beta" on more than 1.7 million Army recruits. ${ }^{55}$

On the heels of the success of the Army tests, members of the American Psychological Association called for civilian uses of the Army

48. See infra Part II.

49. See generally Wilson, supra note 2. During the first two decades of the twentieth century, standardized tests assessed students on all subjects, building from Joseph Rice's spelling surveys in the 1890s to Lewis Terman's revision of the Binet intelligence scale in 1916, and fast became the preferred testing method of higher education admissions. Nadia Behizadeh \& George Engelhard Jr., Historical View of the Influences of Measurement and Writing Theories on the Practice of Writing Assessment in the United States, 16 AsseSsing Writing 189, 194-97 (2011); Walt Haney, Validity, Vaudeville, and Values: A Short History of Social Concerns Over Standardized Testing, 36 AM. PSYCHOL. 1021, 1022 (1981) (citation omitted).

50. See College Entrance Examination Bd. Middle States \& Md., Plan of ORganization of THE COLlEgE ENTRANCE EXAMINATION BOARD FOR THE MidDLE StATES AND Maryland and a Statement of SubJects in Which Examinations Are Proposed (1900). Founding institutions included Columbia University, Colgate University, University of Pennsylvania, New York University, Barnard College, Union College, Rutgers University, Vassar College, Bryn Mawr College, Women's College of Baltimore (now Goucher College), Princeton University, Cornell University, Newark Academy, Mixed High School, New York, and Collegiate Institute, New York. Id. at 4-5.

51. About Us, C. BD., http://www.collegeboard.org/about [https://perma.cc/UL9K-BSDT].

52. See Haney, supra note 49 , at 1022.

53. See id.

54. See generally id.

55. Id. at 1022. Yerkes offered the "Army Alpha tests for literates and the Army Beta tests for illiterates." Id. The data derived from these tests were the prime source for studying demographics in the United States for many years following the war. Id. 
tests. ${ }^{56}$ Brigham joined the Princeton faculty as a psychology professor ${ }^{57}$ and in 1923 published what became a highly influential book, A Study of American Intelligence. ${ }^{58}$ Analyzing the data from the Alpha and Beta tests, Brigham concluded that native-born Americans had the highest intelligence out of the groups tested. ${ }^{59}$

In 1925, Brigham adapted the Army tests for use in admissions to Princeton. ${ }^{60}$ Brigham's admissions test became known as "the Princeton Test." ${ }^{\prime \prime}$ In 1926, the College Board hired Brigham to create a college admissions test for nationwide use. ${ }^{62}$

The Princeton Test became the Scholastic Aptitude Test (SAT).

The College Board introduced the SAT for all college admissions in 1926, setting off a decade of proliferation of standardized testing. ${ }^{63}$ By 1938, 4,000 standardized tests assessed education, personality, and

56. Lee Cronbach, Five Decades of Public Controversy Over Mental Testing, 3 AM. PsYCHOL. 1, 3 (1975). Volume 5 of the Reader's Guide, 1919-1921, listed titles such as Applying the army trade tests in vocational schools, Industrial Arts Magazine, October 1919; Army Alpha in the normal schools, School and Society, April 16, 1921; Army intelligence test as a means of prognosis in high school, School and Society, April 16, 1921; Extension of selective tests to industry, Annals of American Academy, January 1919; and Intelligence examinations and admission to college, Education Review, February 1921. Haney, supra note 49, at 1022.

57. See generally EDWIN Black, War Against the WeAK: Eugenics and AMERICA's CAMPAIGN TO CREATE A MASTER RACE (2004). Brigham quickly becoming a pioneer in the field of psychometrics, a field concerned with the theory and technique of psychological measurement of skills, knowledge, abilities, attitudes, personality traits, and educational achievement. Psychometrics was inextricably intertwined with eugenics, and eugenics became an academic discipline at many colleges and universities, receiving funding from many sources. Id.

58. See generally CARL C. BRIGHAM, A STUDY OF AMERICAN INTELLIGENCE (1923).

59. See BLACK, supra note 57. Brigham proclaimed the intellectual superiority of the "Nordic Race" and the inferiority of the "Alpine" (Eastern European), "Mediterranean," and "Negro" races and argued that immigration should be carefully controlled to safeguard the "American Intelligence." See id. at 82-83. In support, Brigham wrote:

We must face a possibility of racial [] mixture here that is infinitely worse than that faced by any European country today, for we are incorporating the Negro into our racial stock, while all of Europe is [] free from this [] .... The decline of American intelligence will be more rapid than the decline of the intelligence of European nations [], owing to the presence here of the Negro.

BRIGHAM, supra note 58, at 210. Brigham's early writings heavily influenced the eugenics movement and anti-immigration legislation in the United States in 1924. See BLACK, supra note 57, at 82-85. In 1930, Brigham acknowledged that due to having used prejudicial test administration and analytical techniques in his original research, his conclusions were "without foundation." C. C. Brigham, Intelligence Tests of Immigrant Groups, 37 PSYCHOL. REV. 158, 165 (1930). Brigham admitted, "that study with its entire hypothetical superstructure of racial differences collapses completely." supra at 164.

60. Nicholas Lemann, The Big Test: The Secret History of the American MERITOCRACY 30-31 (2000).

61. Id.

62. WILSON, supra note 21 , at 18.

63. Haney, supra note 49, at 1024. 
vocational aptitude. ${ }^{64}$ The impact of Brigham's original test design for the Army and his conclusions regarding the intelligence and abilities of test takers became permanent. ${ }^{65}$ Standardized testing-rubrics of classification and social superiority — remain a fixture in education assessment.

\section{Fifty Years of Standardization in College Entrance and Placement Essay Examinations}

Academics in the twentieth century embraced standardization in essay testing with a vengeance, effectively continuing to enforce selectivity in admissions and placement. The SAT and other large-scale statewide writing assessments now combined direct writing assessment with multiple-choice testing. ${ }^{66}$

Students' SAT scores did not equate with success in college writing classes, however, and pretty close to immediately, college educators began to complain that matriculating students had poor writing skills. ${ }^{67}$ The College Board responded by introducing the "Writing Sample," a standardized essay prompt designed for college admissions and placement. ${ }^{68}$ But the academic community was skeptical of the new measurement; in the same way that the Hill test produced a subjective assessment of "correct" grammar and English usage, the Writing Sample test could not reliably measure a student's writing ability. ${ }^{69}$

And so, the College Board established the Educational Testing Service (ETS) to create, study, test, and administer tests. ${ }^{70}$ Colleges made both admissions and placement decisions based on test scores. ${ }^{71}$

The ETS spearheaded a study to create a reliable grading rubric for essay examinations. ${ }^{72}$ In an attempt to cover all possible contingencies with the reliability aspect of the rubric, ETS assembled readers, held discussions of the "rules" for grading students' responses to the essay topic, graded sample papers, discussed the results, and then revised the

64. Id. at 1023 (citation omitted).

65. Stephan Jay Gould, The Mismeasure of MAN 233-35 (1981).

66. Ruth Mitchell, Ctr. FOR Pub. Educ., A Guide to Standardized Testing: The NATURE OF ASSESSMENT (2006).

67. WILSON, supra note 21, at 20.

68. See generally Ruth B. Ekstrom, Use of the CEEB Writing Sample, ETS RES. REP. SERIES, June 1962, at i.

69. WILSON, supra note 21, at 20.

70. Id.

71. Paul B. Diederich, John French \& Sydell T. Carlton, Factors in Judgments of Writing Ability, ETS. RES. REP. SERIES, Dec. 1961, at i, 1-3.

72. Hunter M. Breland, Educ. Testing Serv., The Direct Assessment of Writing Skill: A MEASUREMENT REVIEW 1 (1983), https://research.collegeboard.org/sites/default/files/publications/ 2012/7/researchreport-1983-6-direct-assessment-writing-measurement.pdf [https://perma.cc/ZU5JRA2J]. 
rubrics. ${ }^{73}$ The ETS then compared readers' scores. ${ }^{74}$ If the scores were the same, ETS deemed the results reliable. ${ }^{75}$ If the readers assigned different scores to the same essays, the scores were deemed unreliable. ${ }^{76}$

The ETS study was severely flawed, however, and soon revealed the biases of the researchers: ETS researchers ${ }^{77}$ explained how they gave 300 student papers to fifty-three "distinguished readers" from various fields of study and told them to sort the papers into nine piles, using whatever judgments they generally used when looking at a piece of writing. ${ }^{78}$ The researchers expected these readers to arrive at different assessments of the papers, acknowledging that "if their grades do not agree, it is not for lack of interest, knowledge, or sensitivity, but because competent readers with their diversity of background will genuinely differ in tastes and standards." ${ }^{\prime 79}$ Ultimately, the research revealed that 111 of the 300 papers received eight of nine possible grades, and no paper received less than five different grades. ${ }^{80}$

To create a standardized scoring tool out of the variable scores, the ETS researchers grouped the assessments into the five essential factors of good writing:

1. Ideas: relevance, clarity, quantity, development, persuasiveness

2. Form: organization and analysis

3. Flavor: style, interest, sincerity

4. Mechanics: specific errors in punctuation, grammar, etc.

5. Wording: choice and arrangement of words[. $]^{81}$

The five factors reflected the imposition of the researchers' own categorization of writing assessment on the complex process of evaluating the nuances of writing, ${ }^{82}$ with the result that ETS continued to ensure that college admission was only available to students with higher social status. $^{83}$

73. Id. at $84-87$.

74. Id.

75. $I d$.

76. Id.

77. Id.

78. Diederich, French \& Carlton, supra note 71, at 10-11.

79. Id. at 10 .

80. Id. at 10-17. "Anyone who has ever submitted to the mortal agony of grading and commenting on 300 papers will give these readers heartfelt thanks." Id. at 10.

81. WILSON, supra note 21 , at 22.

82. Id. at 22-23; see also Kathleen Blake Yancey, Looking Back as We Look Forward: Historicizing Writing Assessment, 50 C. COMPOsITION \& COMM. 483, 483-503 (1999).

83. David A. Gamson, Kathryn A. McDermott \& Douglas S. Reed, The Elementary and Secondary Education Act at Fifty: Aspirations, Effects, and Limitations, RSF J. Soc. ScI., Dec. 2015, 
In 1965, in response to the ongoing status issues in assessment for education and during the next wave of major immigration to the United States ${ }^{84}$ Congress enacted the Elementary and Secondary Education Act of 1965 (ESEA), allocating significant resources to states via federal grants to meet the needs of educationally deprived children. ${ }^{85}$ The ESEA did not require students to meet performance expectations on standardized tests. $^{86}$

The allocation of resources to the less fortunate combined with the onset of the 1970s - the twentieth century's own period of social enlightenment - brought a sort of assessment renaissance to education, and educators succeeded in their push for writing assessments designed and implemented at the local, programmatic, and classroom levels. ${ }^{87}$ As writing teachers began designing their own assessments, the methods of assessment diversified, resulting in a shift to three new methods of holistic writing: timed essay tests, locally designed rubrics, and portfolios (which assessed a collection of student work. ${ }^{88}$ These assessments were considered a more holistically based scoring mechanism. ${ }^{89}$

The assessment renaissance was short-lived, however. The onset of the 1980s, and a sharp turn from the progressivism of the 1970s, halted the holistic assessment movement, ushering in a decade of "Standards and Accountability." ${ }^{90}$ Attempting to respond to the perceived general decline

at 1, 6 ("As of 1961, many middle-class Americans could remain comfortable with the notion that poor children need only apply themselves should they wish to escape poverty; indeed, an idea that has run throughout American history is that some poor people are undeserving of help because they brought poverty on themselves. That complacency was shattered the following year with the publication of Michael Harrington's The Other America: Poverty in the United States . . . 'The real explanation of why the poor are where they are,' Harrington wrote, 'is that they made the mistake of being born to the wrong parent, in the wrong section of the country, in the wrong industry, or in the wrong racial or ethnic group."').

84. Immigrants primarily came from Asian countries and Mexico. The Immigration and Nationality Act of 1965, also known as the Hart-Celler Act, changed the way quotas were allocated by ending the National Origins Formula that had been in place in the United States since the Emergency Quota Act of 1921. See Immigration and Nationality Act of 1965, Pub. L. No. 89-236, 79 Stat. 911 (codified as amended in scattered sections of 8 U.S.C. Ch. 12).

85. Elementary and Secondary Education Act of 1965, Pub. L. No. 89-10, 79 Stat. 27 (codified as amended at 20 U.S.C. ch. $70(2012)$ ).

86. Gamson, McDermott \& Reed, supra note 83, at 2.

87. See Brian Huot, (Re)Articulating Writing AsSessment for Teaching and LEARNING 33 (2002).

88. Id. at 35-36.

89. See Yancey, supra note 82, at 484.

90. See generally NAT'L COMM'N ON EXCELlENCE IN EdUC., A NATION AT RisK: THE IMPERATIVE FOR EDUCATIONAL REFORM NATIONAL COMMISSION ON EXCELLENCE IN EDUCATION (1983), https://www2.ed.gov/pubs/NatAtRisk/risk.html [https://perma.cc/5EZH-B48V]. Reagan-era "standards-based education" reform began with the publication of the report of the National Commission on Excellence in Education: "[T]he educational foundations of our society are presently 
of education, federal education policy called for the "effectiveness" of both schools and individual educators at all levels to be assessed by students' scores on standardized tests. ${ }^{91}$ Schools devised challenging standards in English and math, and required all students to take tests based on those standards at three points in their schooling. ${ }^{92}$ The federal government held schools and school districts accountable for students' performance and teachers' effectiveness. ${ }^{93}$

Another decade later, Congress began using ESEA as leverage for standards-based reform. ${ }^{94}$ In 1991, the Bush Administration introduced "America 2000," a proposal for national standards and standardized testing, which included researchers, businesses, and labor in curriculum development. ${ }^{95}$ Although the AMERICA 2000 Excellence in Education Act was never realized, the federal government authorized funds to support voluntary national curriculum standards. ${ }^{96}$

Then, in 1994, Congress reauthorized the ESEA to align Title I with the standards-based reforms that many states had enacted beginning in the

being eroded by a rising tide of mediocrity that threatens our very future as a Nation and a people." Id. at 9 .

91. NAT'L ACAD. OF EDUC. WORKING GRP. ON STANDARDS, ASSESSMENTS, AND ACCOUNTABILITY, STANDARDS, AsSESSMENTS, AND ACCOUNTABILITY: EDUCATION POLICY WHITE PAPER 7-14 (2009), https://files.eric.ed.gov/fulltext/ED531138.pdf [https://perma.cc/WQK3-PDF2].

92. Id. at 5-6.

93. Id. at 7 .

94. Lorraine M. McDonnell, No Child Left Behind and the Federal Role in Education: Evolution or Revolution? 80 Peabody J. EduC. 19, 25 (2009). During Ronald Reagan's and George H. W. Bush's administrations, expenditures for federal education programs were reduced, and the federal role, at least as articulated by President Reagan, shifted:

The emphasis was on the persuasive function of the federal government through the president's use of his 'bully pulpit' and direct access to the American people, rather than on its regulatory role as a funder of categorical programs. Not only did the mode of federal influence over states and localities change, but the terms of the national discourse shifted from educational opportunity and equity to educational excellence.

Id.

95. See AMERICA 2000 Excellence in Education Act, H.R. 2460, 102d Cong. (1991). "America 2000" was a national strategy (not a federal program) designed to accomplish in nine years the six National Education Goals first articulated by President George H. W. Bush and the state governors at the 1989 Education Summit in Charlottesville, Virginia, as follows: (1) all children in America will start school ready to learn; (2) high school graduation rate will increase to at least ninety percent; (3) U.S. students will demonstrate competency in English, math, science, history, and geography at grades four, eight, and twelve with the goal of productive and responsible citizenship; (4) U.S. students will be first in the world in science and math achievements; (5) every American adult will be literate to compete in a global economy and exercise the rights and responsibilities of citizenship; and (6) every school in America will be free of drugs and violence and will offer a disciplined environment conducive to learning. Goals 2000 and ESEA, ClintON Digital LiBraRY, http://clinton. presidentiallibraries.us/exhibits/show/education-reform/goals-esea [https://perma.cc/F4PJ-A7FP].

96. President Clinton signed into law the Goals 2000: Educate America Act (Goals 2000) in 1994 to codify the National Education Goals and offer grants to states that committed to specific plans for systematic reform of $\mathrm{K}-12$ education. Goals 2000 included testing of reading and mathematics skills to ensure such students met these standards. Goals 2000 and ESEA, supra note 95. 
1980s. ${ }^{97}$ As a condition for receiving Title I funds, states were now required to set challenging standards in math and English. ${ }^{98}$ Title I students and non-Title I students took the same tests on the same standards-a departure from past practice, which allowed schools to assess the progress of Title I students with "basic skills" tests. ${ }^{99}$

Under the Improving America's Schools Act of 1994 (IASA), federal involvement in $\mathrm{K}-12$ education began to reach the core functions of elementary and secondary education for the first time, once again setting a new precedent for federal mandates. ${ }^{100}$ IASA's changes required all states to develop educational standards that required student assessment at least once at the elementary level, once in middle school, and once again in high school. ${ }^{101}$ Schools that failed to meet performance standards were required to devise a school improvement plan to ensure capacity to meet the new standards. ${ }^{102}$

For the first time, the federal government required schools to realize performance benchmarks to receive Title I funding. ${ }^{103}$ Thus, the federal government expanded its educational ambitions under Title I, moving from addressing the educational disadvantages of children in poverty to creating a regulatory structure that sought to incentivize systemic reform throughout public schools. ${ }^{104}$

When the ESEA was up for reauthorization in 2001, Congress renamed the Act the No Child Left Behind Act (NCLB) and drastically changed the nature of its provisions regarding assessment. ${ }^{105}$ While programs still focused on "improving the education of the disadvantaged," the NCLB now also required students to meet performance expectations on standardized tests. ${ }^{106}$ NCLB expansion of federal educational ambitions required states to meet educational content standards, test students on

97. LAURA S. HAMILTON, BRIAN M. STECHER \& KUN YUAN, RAND CORP., STANDARDS-BASED REForm in the United States: History, ReSEARCh, AND Future Directions 10 (Dec. 2008), https://www.rand.org/content/dam/rand/pubs/reprints/2009/RAND_RP1384.pdf [https://perma.cc/RD6K-AF2M].

98. Margaret E. Goertz, Implementing the No Child Left Behind Act: Challenges for the States, 80 PEABOdY J. EDUC. 73, 76-77 (2009).

99. Lorraine M. McDonnell, Stability and Change in Title I Testing Policy, RSF J. Soc. ScI., Dec. 2015, at 170, 174 n.4. (2006).

100. Paul Manna, School's In: Federalism and the National EduCATion Agenda 100

101. NAT'L ACAD. OF EDUC. WORKING GRP. ON STANDARDS, ASSESSMENTS, AND ACCOUNTABILITY, supra note 91 , at 30 .

102. Id.

103. Id.

104. $I d$.

105. Id.

106. Gamson, McDermott \& Reed, supra note 83, at 2. 
those standards, and hold schools and districts accountable for their students' test scores. ${ }^{107}$

The condensed history above details a trajectory of rubrics as developed initially to create barriers to access to higher education for lower income and immigrant applicants. Later, rubrics materialized in the form of standardized tests, ostensibly designed to reflect objectivity in assessment but unavoidably subjective. As the federal government glommed onto standardized testing as a method of controlling funding to public schools, exclusionary motivations became legislation: students are assessed on standardized scales, educators are assessed for effectiveness, and learning takes a back seat to "teaching to the test." School systems with better means and students with higher family incomes continue to surpass students of lesser means in federal "scoring systems," and educational institutions continue to rank students according to inherent knowledge or ability.

Rubrics used in legal education mirror the selective result of assessment and ranking in the early centuries of U.S. education. The standard rubrics used in primary education, ${ }^{108}$ middle school, ${ }^{109}$ secondary education, college, and legal education ${ }^{110}$ continue to exemplify social ranking in furtherance of the discriminatory practices instituted at the turn of the eighteenth century. Although not as explicit as it was in prior centuries, writing assessment practices using rubrics in law education remain silently selective. ${ }^{111}$ The selectivity of rubrics not only maintains discrimination in education evaluation but also creates a whole host of additional problems in all aspects of education, from teaching to learning.

\section{PROBLEMS OF RUBRICS DETAILED}

In 2015, I circulated a nineteen-question survey (survey) on the use of rubrics to professors in the legal academy. ${ }^{12}$

Criteria for participating in the survey was that a professor assign a written assessment, such as a legal brief or other written legal analytical assignment. I received approximately 200 responses from law professors in subjects including Legal Writing and Research, Evidence, Professional Responsibility, Civil Procedure, Tax, Administrative Law, Legal History, Bankruptcy, Employment Law, Poverty Law, Mediation, Contracts, Torts,

107. Id.

108. See infra App. 2, Rubrics, at 772-85.

109. See id. at 787-94 (sixth and seventh grade rubrics).

110. See id. at 69-71 (sample law school contracts class rubric).

111. See generally EdUARdo Bonilla-Silva, Racism Without Racists: COLOR-BLind RACISM AND THE PERSISTENCE OF RACIAL INEQUALITY IN AMERICA (2006).

112. See infra App. 1, Survey Results. This survey was circulated to the Legal Writing Institute, select AALS section lists, and other legal educator member listservs. 
Business Associations, Trusts and Estates, Environmental Law, and Legal Advocacy, among other discrete course offerings. ${ }^{113}$ Responses regarding rubrics used in courses such as Contract Drafting, which does not require the same type of narrative legal analysis as a brief or other written analytical assignment, were disregarded.

I did not specifically define the term "rubric" within the survey. There is a general understanding within the legal academy regarding the definition of rubrics in their many forms as used in assessment of student written work. A statistically insignificant number of participants had difficulty grasping the concept of a rubric and attacked the survey; those answers were stricken.

Cumulatively, the survey revealed that $80 \%$ of law educators use some kind of rubric in assessment of writing. In the first part of the survey, the answers strongly favored rubric use. But as the questions became more focused and called for narrative explanations, participants provided detailed, thoughtful responses, some of which revealed the same difficulties with rubrics encountered by teachers using the Hillegas Scales, revealing the same problems and biases detailed in Part I.

There are generally two kinds of assessment: holistic evaluation and analytical rubrics. Holistic evaluation assesses the overall quality of a student's work without a detailed, point-oriented score sheet. ${ }^{114}$ Holistic evaluation is more product-oriented than process-oriented and is primarily concerned with total performance rather than with the individual steps taken to arrive at the final product. ${ }^{115}$

By contrast, analytical rubrics consist of multiple, separate scales and provide a set of point scores that are summed up to provide a single score. ${ }^{116}$ These are the rubrics that instructors of legal analysis have been cultivating and using in recent years, where there are certain points assigned for grammar, content, and structure in writing assignments. ${ }^{117}$

There is a perception among law educators that holistic evaluation of legal analytical writing can be subjective, unreliable, and invalid. To that extent, a regular inquiry on my professional listserv is a request for an analytical rubric:

I am interested in having my students complete a detailed selfassessment of a client letter assignment using a model answer. Does

113. Survey Question \#1 asked: "What subjects do you teach?"

114. Ali Reza Rezaei \& Michael Lovorn, Reliability and Validity of Rubrics for Assessment Through Writing, 15 ASSESSING WRITING 18, 19 (2010).

115. Id.

116. Id.

117. Id. 
anyone have any sample rubrics or other materials for this type of exercise?

As part of an open memo assignment, I am asking my 1 Ls to conduct a brief video-taped client interview. I am looking for examples of self-assessment and peer-assessment rubrics to use with this this simulation.

I'm looking at our school's upper-level writing requirement and also our school's upper-level oral presentation requirement. If you have some kind of grading rubric or assessment tool that you use at your school, would you be willing to share?

We are in the process of incorporating 302(d) skills into our curriculum and the faculty has chosen collaboration and client counseling as our skills. I would be grateful for any sources that talk about teaching these skills, any exercises you use, and, in particular, any rubrics you have developed to evaluate these skills.

I am writing on behalf of a colleague who has just taught her first seminar class. Students in the class are required to write a scholarly writing paper. My colleague is looking for a grading rubric for seminar or scholarly writing papers. ${ }^{118}$

Creating a rubric takes so much time-sometimes several yearsand educators would rather someone else do all that work. And yet, when finally grading according to the rubric, either as developed, borrowed, or modified, there is something that cannot quite be quantified-something that might be very good - something that the student cannot get "credit" for because it is not accounted for on the rubric.

Rubric invalidity is more troublesome than the alleged trouble of subjectivity in holistic evaluation. As we learned from the Hillegas Scales and other forms of standardized assessment in early twentieth century education and college admission, rubrics to assess legal analytical writing that are "supposed" to make grading easier with promises of simplicity and objectivity cannot account for the nuances of communication in legal analysis and the effect of the creative expression of that analysis on the reader. As one survey participant noted, rubrics "[1]ead [sic] students to believe that legal writing assignment can be assessed solely by means of objective criteria, when in fact, there is necessarily a subjective component to grading these assignments." 119

The ease of rubric-oriented assessment is accompanied by serious measurement errors: while rubrics tend to improve interrater reliability,

118. Emails between listserv members of the Legal Writing Institute (on file with author). The author has concealed the identities of the senders to protect their anonymity.

119. Infra App. 1, Survey Results, at 754. 
consistency in assessment is not achieved because rubrics limit the scope of variability of scores. ${ }^{120}$ In effect, rubrics provide no real consistency but rather a vehicle for expressing naturally occurring agreement. ${ }^{121}$ After all, "[t]he fewer the choices, the fewer the possibilities for disagreement among scorers, and fewer but more serious the measurement errors." 122

A study by Berkeley Professor Sarah W. Freedman identified rubrics' interrater unreliability. ${ }^{123}$ In the study, students and professional writers received the same writing prompt and the teachers reviewed the written results. ${ }^{124}$ When the teachers assessed the students' work using a rubric, the professional writers scored lower than the students: Freedman found that teachers could be biased against student writing that appears "threateningly familiar[.]" 125 The rubric failed to account for the sophistication and variety of approaches that professional writers brought to the prompt: ${ }^{126}$ "In cases where the overall effect of student performance is achieved by means not anticipated in the scoring criteria, criterial analysis of the quality of writing will deflect a scorer's attention away from the actual writing, and the score will not support valid inferences about the student's achievement." 127

Rubrics standardize not only the scoring but also the teaching of writing, which jeopardizes the learning and understanding of legal analysis. ${ }^{128}$ The following Subparts identify problems associated with the use of rubrics in legal assessment, incorporating, when applicable, the Survey results.

\section{A. Rubrics Focus on Summative Assessment, Decreasing Metacognition}

In addition to the inherent validity concerns, rubrics also impede the way students think. Assessment of learning is generally broken down into two categories: formative assessment and summative assessment. The goal of formative assessment is to monitor student learning by providing ongoing feedback. ${ }^{129}$ In formative assessment, students improve their

120. Linda Mabry, Writing to the Rubric: Lingering Effects of Traditional Standardized Testing on Direct Writing Assessment, 80 PHI DELTA KAPPAN 673, 675 (1999).

121. Id.

122. $I d$.

123. See generally Sarah Warshauer Freedman, The Registers of Student and Professional Expository Writing: Influences on Teachers' Responses, in NEW DIRECTIONS IN COMPOSITION RESEARCH 334 (Richard Beach \& Lillian S. Bridwell eds., 1984).

124. Id. at $335-36$.

125. Id. at 344 .

126. Id.

127. See Mabry, supra note 120 , at 675.

128. Rezaei \& Lovorn, supra note 114, at 27-30.

129. Formative Assessment, THE GLOSSARY OF EDUC. REFORM, http://edglossary.org/ formative-assessment/ [https://perma.cc/M5GA-QCQA]. 
learning when instructors identify students' strengths and weaknesses and target areas of concern that require more work. ${ }^{130}$ Formative assessments, therefore, are "low stakes," that is, there is no grade or point value assigned to the work as the student is in the process of learning. ${ }^{131}$

The goal of summative assessment, by contrast, is to evaluate student learning at the end of an instructional unit by comparing the student's work against some generalized standard or benchmark. ${ }^{132}$ Summative assessments are often "high stakes," accompanied by a corresponding grade or point value, such as a midterm, final project, or paper. ${ }^{133}$

The authors of The Carnegie Report (Carnegie) described legal education assessment as largely summative throughout-beginning with the LSAT, continuing through law school exams, and culminating in the bar exam. ${ }^{134}$ Carnegie examined the failures in law education and provided recommendations for education reform. ${ }^{135}$ One of Carnegie's admonishments to law educators is that a continued focus on summative assessment rather than formative assessment in law education interferes with metacognition. ${ }^{136}$ Metacognition refers to the self-monitoring by an individual of his or her own unique cognitive processes: having both awareness and control over one's own learning and thinking. ${ }^{137}$ "[The] after-the-fact character of summative assessment, however, forecloses the possibility of giving meaningful feedback to the student about progress in learning. In contrast, formative assessment provides feedback in order to support opportunities to improve learning as the course proceeds." 138

Metacognivity focuses on reflexivity in thought processes, that is, the development of critical reasoning, the very core of legal education. ${ }^{139}$ In learning, awareness and control of cognitive processes permit individuals

130. David J. Nicol \& Debra MacFarlane-Dick, Formative Assessment and Self-Regulated Learning: A Model and Seven Principles of Good Feedback Practice, 31 STUD. Higher EDUC. 199, 199-200 (2006).

131. Eberly Ctr., What Is the Difference Between Formative and Summative Assessment?, CARNEGIE MELLON UNIV., https://www.cmu.edu/teaching/assessment/basics/formative-summative. html [https://perma.cc/JCV3-4LXZ].

132. Id.

133. Id.

134. William M. SUllivan ET AL., EduCATing LAWYERS 188-89 (2007).

135. Id. passim.

136. Id. at 189.

137. Anthony S. Niedwiecki, Lawyers and Learning: A Metacognitive Approach to Legal Education, 13 WIDENER L. REV. 33, 35 (2006).

138. SUlLIVAN, supra note 134, at 164.

139. Barry J. Zimmerman, Self-Regulated Learning and Academic Achievement: An Overview, 25 EDUC. PSYCHOLOGIST 3, 4-5 (1990) (noting that students with strong metacognitive skills can "plan, set goals, organize, self-monitor, and self-evaluate at various points during the process of acquisition" and that doing so allows them to be "self-aware, knowledgeable, and decisive in their approach to learning"). 
to plan and prepare, monitor learning progress, and reflect on knowledge. ${ }^{140}$ Critical reasoning requires the application of concepts to a new problem where there is no standard result. Teaching to a rubric does not foster metacognitive learning: "To foster meaningful application and transfer of learning, student reflection is key ... metacognitive strategies provide the necessary format to promote learning not just for a test, but for a lifetime - not just for recall, but for lifelong logic and reasoning."141

The holistic rubric is the method by which most law educators formerly evaluated student analytical writing. But with the many changes in legal education in admissions and teaching, many law educators turned to rubrics composed of charts with boxes and point values, and interminable narrative lists with accompanying point values. ${ }^{142}$ Assessment of student analytical writing remains fully summative, as observed in Carnegie. ${ }^{143}$

Additionally, law educators go to great lengths to develop rubrics for grading student written work in an attempt to fulfill American Bar Association (ABA) Standards requiring multiple opportunities for feedback. In so doing, however, law educators misinterpret the purpose of the ABA Standards.

ABA Standard 304 requires that law educators provide multiple opportunities for performance and feedback from faculty:

Standard 304. Simulation Courses and Law Clinics

(a) A simulation course provides substantial experience not involving an actual client, that (1) is reasonably similar to the experience of a lawyer advising or representing a client or engaging in other lawyering tasks in a set of facts and circumstances devised or adopted by a faculty member, and (2) includes the following: (i) direct supervision of the student's performance by the faculty member; (ii) opportunities for performance, feedback from a faculty member, and self-evaluation; and (iii) a classroom instructional component. ${ }^{144}$

140. Id.

141. Robin Fogarty, How to Teach For Metacognitive Reflection, at xvii (1994).

142. Jessica Clark \& Christy DeSanctis, Toward a Unified Grading Vocabulary: Using Rubrics in Legal Writing Courses, 63 J. LegAL EdUC. 3, 7-8 (2013).

143. See generally SULLIVAN ET AL., supra note 134.

144. AM. BAR ASS'N, ABA STANDARDS AND RULES OF PROCEDURE FOR APPROVAL OF LAW SCHOOLS 2017-2018, at 17 (2017) (emphasis added),

https://www.americanbar.org/content/dam/aba/publications/misc/legal_education/Standards/201720 18ABAStandardsforApprovalofLawSchools/2017_2018_aba_standards_rules_approval_law_school s_final.authcheckdam.pdf [https://perma.cc/JH5A-DKXF]. 
Law educators interpret Standard 304 as fulfilled through reporting the results of assignments graded according to rubrics. ${ }^{145}$ But on its face, Standard 304 delineates the metacognitive processes necessary to perform independently as a practicing attorney. The language of Standard 304 does not imply that law educators should assemble a checklist of items that students must memorize.

Similarly, ABA Standard 302 requires the establishment of learning outcomes and competencies in the areas of critical analysis and legal reasoning, both of which require independent judgment on each new set of facts:

Standard 302. Learning Outcomes

A law school shall establish learning outcomes that shall, at a minimum, include competency in the following: (a) Knowledge and understanding of substantive and procedural law; (b) Legal analysis and reasoning, legal research, problem-solving, and written communication in the legal context; (c) Exercise of proper professional and ethical responsibilities to clients and the legal system; and (d) Other professional skills needed for competent and ethical participation as a member of the legal profession. ${ }^{146}$

The use of rubrics to assess analytical problem-solving abilities does not fulfill the ABA's outcomes and assessments requirements. Following a predetermined list of activities in a set order to satisfy a rubric hinders the development of critical analytical thinking.

In The Checklist Manifesto, Atul Gawande suggests that using checklists in various professions can help reduce errors in performance. ${ }^{147}$ While there is support in the literature on assessment in legal analysis for relying on checklists in the developing or organizing phase of a written work, ${ }^{148}$ the practice of law is dissimilar to other professions that require a

145. Susan Duncan, The New Accreditation Standards Are Coming to a Law School Near YouWhat You Need to Know About Learning Outcomes \& Assessment, 16 J. LEgAL Writing InST. 605, 625 (2010) ("In recognizing that more assessments and more intentional design of assessments is contrary to most law school's practice and culture, the authors also encourage law professors to develop clear grading criteria through checklists, rubrics, or samples to help save time.") (citation omitted); Sophie M. Sparrow, Describing the Ball: Improve Teaching by Using Rubrics-Explicit Grading Criteria, 2004 Mich. ST. L. REV. 1, 8 (2004).

146. $I d$. at 15 .

147. See generally ATUl GAWANDE, THE CHECKLIST MANIFESTO (2009).

148. Jennifer Murphy Romig, The Legal Writer's Checklist Manifesto, 8 LEgAL COMM. \& RHETORIC 93, 105 (2011); Laura A. Calloway, Simple Steps: Improving Your Performance with Checklists, L. PRAC., July-Aug. 2010, at 18, https://www.americanbar.org/publications/ law_practice_home/law_practice_archive/lpm_magazine_articles_v36_is4_pg18.html [https://perma.cc/AU99-J5FN]; Josh Douglas, The Checklist Manifesto: A Book that Altered How I View the World, PRAWFSBLAWG (July 9, 2013, 1:09 AM), http://prawfsblawg.blogs.com/ 
set of ordered procedures to achieve consistent, identical results. Unlike in professions such as medicine, aviation, or architecture, where, as Gawande suggests, a series of steps must be adhered to and checked off to achieve exact results, ${ }^{149}$ legal analytical persuasion is by its nature creative and should not be wholly bound by a strict checklist structure. A natural flow-in response to unanticipated legal interpretations and hypothetical issues - requires the development of nuances in legal analysis. Reducing errors is only part of the success of legal analysis; critical legal analysis requires creativity in problem-solving, which is not produced by adhering to a specific checklist designed primarily to reduce errors.

The additional metacognitive goal of self-evaluation is further defeated by the rubric: The primary goal of metacognitive development is to develop students' abilities to become self-regulated learners - to learn about their own thinking processes so they can use the standards of the given discipline to recognize personal shortcomings in problemsolving. ${ }^{150}$ Similar to college instructors, as law professors we use our own metacognition to draw out critical thinking abilities in our students:

The primary goal is to help students learn to think about their own thinking so they can use the standards of the discipline or profession to recognize shortcomings and correct their reasoning as they go.... What else do the best teachers know that might explain their success in helping students learn deeply? We found two other kinds of knowledge that seem to be at play. First, they have an unusually keen sense of the histories of their disciplines, including the controversies that have swirled within them, and that understanding seems to help them reflect deeply on the nature of thinking within their fields. They can then use that ability to think about their own thinking - what we call 'metacognition'-and their understanding of the discipline to grasp how other people might learn. ${ }^{151}$

A checklist encourages one-dimensional, black-and-white thinking and does not develop critical reasoning skills. As observed by my survey participants, a rubric

prawfsblawg/2013/07/the-checklist-manifesto-a-book-that-altered-how-i-view-the-world.html [https://perma.cc/JXM9-S7ZU].

149. $C f$. GAWANDE, supra note 147, at 115-16. After implementing the use of surgical checklists in eight hospitals, the rate of major complications fell by $36 \%$ and deaths fell by $47 \%$. Id.

150. Barry J. Zimmerman, Becoming a Self-Regulated Learner: An Overview, 41 THEORY INTO PRAC. 65, 65-66 (2002) (explaining that self-regulation is the self-directive process by which learners transform their mental abilities into academic skills, referring to self-generated thoughts, feelings, and behaviors that are oriented to goal attainment). "Learning is viewed as an activity that students do for themselves in a proactive way rather than as a covert event that happens to them in reaction to teaching." Id. at 65 .

151. Ken Bain, What the Best College Teachers Do 25, 160 (2004). 
[s]hifts emphasis of assignments away from learning; inhibits critical thinking; focuses students on points [and] .... [a]ssumes 'one size fits all' categories and strengths/weaknesses for all students[; and] [g]ives students a snapshot of their projects when looking INTO the paper is necessary to see where they had specific issues or successes - even breaking the rubric into parts is not always enough of a breakdown. ${ }^{152}$

In favoring the checklist approach, one survey answer specifically described many of the drawbacks of a rubric-style assessment but characterized those drawbacks as positive:

I appreciate rubric grading for two reasons: First, it reduces or eliminates the reader bias I experience when reading really poorly worded writing rife with grammar, usage, spelling, citation, or general English language mistakes. It allows me to give fair grades on the separate criteria of the assignment without failing or tearing the student down solely because the writing is painful to read. Second, I hand out each rubric ahead of time and instruct the students to read it and apply it, so that they can know my exact expectations, and use the rubric as a self-guided checklist on how to complete the assignment. ${ }^{153}$

The participant believes that bias is reduced-I have already shown that rubrics do not reduce bias. The participant hyper-focuses on grammar and style - the obsession of the late nineteenth century current traditionalists and the early twentieth century Hill and Hillegas Scales and classifications - which are obstacles to assessing legal analytical writing for its critical effectiveness.

\section{B. Rubrics are Reductionist}

Critics of rubrics see rubrics as ultimately reductionist, a wholly disfavored philosophical theory. ${ }^{154}$ Reductionism is the philosophical position that a complex system is defined by the sum of its parts ${ }^{155}$ - the

152. Infra App. 1, Survey Results, at 754-55.

153. Id. at 759.

154. See generally HUOT, supra note 87 . Before the 1950 s, a simple and reductionist notion of "criterion validity," that is, the theory that a test is valid for anything with which it correlates, prevailed. Id. at 48 .

Since the 1950s, validity has been defined in more complex and comprehensive ways that attempt to provide more and more information not only about the test itself, but also about the theoretical framework that supports specific testing practices and the consequences on students and schools that result from the decisions made on the basis of the test.

Id.

155. Melanie Mitchell, Complexity: A Guided Tour 1 (2009). 
belief that everything that exists is made from a small number of basic, predictable substances. ${ }^{156}$

The French philosopher René Descartes first introduced Reductionism in Part V of his Discourse on the Method. ${ }^{157}$ Descartes argued that the world was like a machine made up of pieces that operated like clockwork mechanisms. ${ }^{158}$ The machine could be understood by taking its pieces apart and studying them, and then putting the pieces back together to see the complete picture. ${ }^{159}$

To illustrate Reductionism in practice, in 1739, the French inventor Jacuques de Vaucanson created "automata," or "self-moving machines," the most famous of which was the Canard Digérateur, or "Digesting Duck," a mechanical duck. ${ }^{160}$ The mechanical duck appeared to have the ability to eat kernels of grain, metabolize the kernels, and then defecate the kernels. ${ }^{161}$ While the mechanical duck did not actually have the ability to digest and process food (the food was collected in one inner container, and the pre-stored "feces" was produced from a second container), in de Vaucanson's time this mechanical animal provided the backdrop for "growing confidence, derived from ever-improving instruments, that experimentation could reveal nature's actual design."162

Vaucanson's mechanical duck automated and dramatized the philosophical question that preoccupied society at that time: "[W]hether human and animal functions were essentially mechanical."163 In the eighteenth century, Reductionist thinking and methods formed the basis for theoretical experiments in physics, chemistry, and cell biology. ${ }^{164} \mathrm{In}$ linguistics, Reductionism supported the idea that everything can be described in a language with a limited number of core concepts and combinations of those concepts. ${ }^{165}$

Breck observes that Reductionism is reflected in standardized tests and the rubrics that score the tests, as well as in the flaws that result in the assessment:

156. Id.

157. See generally RenÉ Descartes, Discourse on the Method of RightLy ConduCting One's Reason And of Seeking TRuth in the Sciences (1637). Discourse on the Method is best known as the source of the famous quotation, "Je pense, donc je suis" ("I think, therefore I am"). Id. pt. IV.

158. Id. pt. V.

159. Luke Mastin, Reductionism, PHIL. BASICS (2008), http://www.philosophybasics.com/ branch_reductionism.html [https://perma.cc/G3AD-9UU7].

160. See generally Jessica Riskin, The Defecating Duck, or, The Ambiguous Origins of Artificial Life, 29 CRITICAL INQUIRY 599 (2003).

161. Id. at 608 .

162. Id. at 604 .

163. Id. at 601 .

164. Mastin, supra note 159.

165. Id. 
Think, then, of this comparison: a digesting-duck curriculum for a school subject includes a set of standard parts, so that after a student works through it, she can pour forth its meaning. ... The deep rooted conviction in education that standard units of knowledge can be assembled to cause learning, dates to the time of the digesting duck, when reductionism was infiltrating every intellectual field. ${ }^{166}$

Wilson concludes, and I agree, that by their reductive nature, rubrics are unsuitable for assessing the nuanced nature of written communication. ${ }^{167}$

Survey responses support the rejection of the long-disfavored theory of reductionism. Many participants specifically noted that the assembly or "sum-of-the-parts" aspect of rubrics defeats critical legal thinking:

Students focus too much on the point categories instead of the "big picture." 168

Encourages students to approach assignments in a paint-bynumbers manner. ${ }^{169}$

Students can become too focused on the individual components rather than the overall scope and organization of the assignment. ${ }^{170}$

Rubric grading can miss quality conveyed by a cohesive, overall reading of the document. Students inaccurately assume the rubric is the sum total of all that could be learned or demonstrated. ${ }^{171}$

May occasionally lead to nit-picking over scores assigned to particular criteria. ${ }^{172}$

\section{Rubrics Are Deterministic}

Maja Wilson argues that the grading mechanism of the rubric also depends largely on the disfavored laws of determinism. ${ }^{173}$ Determinism was the nineteenth century philosophical theory that every event or state

166. Judy Breck, Education's Reductionistic Flaw Is Like the Digesting Duck, GOLDEN SwAMP BLOG (Aug. 22, 2009), http://webcache.googleusercontent.com/search?q=cache:DUewHxLrmNoJ: www.prolearnacademy.org/mediabase/blogs/entires $\% 3 \mathrm{Fb}$ start:int $\% 3 \mathrm{D} 60 \% 26 \mathrm{id} \% 3 \mathrm{D} 436+\& \mathrm{~cd}=1 \&$ $\mathrm{hl}=\mathrm{en} \& \mathrm{ct}=\mathrm{clnk} \& \mathrm{gl}=\mathrm{us} \& \mathrm{client}=$ firefox-b-1 [https://perma.cc/8VWG-4GBU] ("Reductionism is the most natural thing in the world to grasp. It's simply the belief that 'a whole can be understood completely if you understand its parts, and the nature of their 'sum." [sic] No one in her left brain could reject reductionism."”).

167. WILSON, supra note 21, at 7.

168. Infra App. 1, Survey Results, at 753.

169. Id.

170. Id. at 754 .

171. Id. at 755 .

172. Id. at 754 .

173. WILSON, supra note 21 , at 32-33. 
of affairs, including every human decision and action, is the inevitable and necessary consequence of antecedent states of affairs. ${ }^{174}$ Determinism promoted the ancient idea that there is no such thing as chance: "Nothing occurs at random, but everything for a reason and by necessity." 175

Wilson illustrates the laws of determinism by describing the game of pool:

If I hit a billiard ball with a specific amount of force in a certain direction, it will move in a predictable way. The billiard table's controlled environment and the laws of physics and geometry interact the same way every time; thus, a software programmer can create a computer billiards game that acts very much like the real thing, minus pool sticks and too-tight Wranglers. ${ }^{176}$

Analytical legal writing, similarly, does not depend on simple linear cause and effect. Legal analytical writing requires consideration of highly complex thoughts and layers of systems, including the interplay between and among statutes and common law, and conflicting precedent authority. Legal analysis can produce many different results and is therefore unpredictable, not unlike "global weather, economic systems or political unrest." 177

To further illustrate the ineffectiveness of determinism in assessment of writing, Bob Broad compares using rubrics to relying on "woefully inadequate" directions or map information. ${ }^{178}$ By way of analogy, Broad uses The Vinland Map. ${ }^{179}$ The Vinland Map was a controversial, medieval-style map line drawing of the "Old World" that depicted a large island in the western Atlantic identified as "Vinilanda Insula." 180 The map, traced to 1440, contained an agenda calculated to please the Catholic prelates assembled for the Council: the captions describe the evangelical Carpini mission to bring the Roman Catholic faith to North America. ${ }^{181}$ According to Broad, the sum of information offered to seafaring travelers by the Vinland Map is as follows:

174. See Determinism, INFO. PHILOSOPHER, http://www.informationphilosopher.com/ freedom/determinism.html [https://perma.cc/QU76-JQ57].

175. Id. (citation omitted).

176. WILSON, supra note 21, at 32.

177. Id.

178. See Bob Broad, What We Really Value: Beyond Rubrics in Teaching and ASSESSING WRITING, at ix (2003).

179. Id. at $\mathrm{ix}-\mathrm{xi}$

180. J. Huston McCulloch, The Vinland Map-Some "Finer Points" of the Debate, OHIO ST. U. DEP'T ECON., http://www.econ.ohio-state.edu/jhm/arch/vinland/vinland.htm [https://perma.cc/4YQJT9A9].

181. Id. 
1. There's land over there.

2. It's a very big piece of land, even bigger than Greenland.

3 . It has a couple of big bays on its east coast.

4. It's ours to claim. ${ }^{182}$

Disregarding the veracity of the last claim, Broad argues that while the Vinland Map may have served perfectly well for its stated purposes in 1440, for anyone living in North America today the map is "bizarrely inaccurate and useless." " 183 For example, the map cannot tell anyone even the most general of directions on streets and highways, or directions to any point of interest in any local municipal area. ${ }^{184}$

Rubrics similarly fail to create a rich and nuanced "map" for evaluating analytical writing. The limitations of the rubric table and point system cannot properly assess the discrete nuances of legal analytical work. For example, when a rubric provides top points for a standard along these lines-" "[e]xercises good judgment in using headings, topic sentences, signposting, etc.," "185 —are we not still struggling with a subjective assessment of "good judgment" and "etc.?" Should organizational constructs such as "headings," "topic sentences," and "signposting" be assessed in the same box and assigned the same points? What if the headings are plentiful and outstanding, but the topic sentences leave a bit to be desired?

Rubrics are used to judge and encourage conformity and an overly formal style. Beyond that failure, the interpretation of the requirements remains subjective. When legal analytical writing is evaluated for individuality, creative thought, and application of content, both the reader and the writer are able to internalize the comments and improve. By contrast, rubrics erect a wall between the individual reader and the written text when the reader is forced to provide a pigeonhole assessment. Prepackaged and processed feedback is neither helpful nor specifically instructive to the legal writer. ${ }^{186}$

My survey participants identified the numerous constraints of the rubric, that is, not providing for the following: a high-level of creative thought, fluidity in writing, or problem-solving (applying the existing law to a fictionalized set of facts). The results are deterministic writing:

182. BROAD, supra note 178 , at $\mathrm{ix}-\mathrm{x}$.

183. Id. at $\mathrm{x}$.

184. See id.

185. Legal Analytical Rubric (2011) (on file with author).

186. See generally BROAD, supra note 178. 
Assumes "one size fits all" categories and strengths/weaknesses for all students. Gives students a snapshot of their projects. ${ }^{187}$

Too vague; hard for students to know exactly what to do to improve. ${ }^{188}$

Rubrics may not cover the bleeding of errors between categories; rubrics may not cover all aspects of effective communication. ${ }^{189}$

Inhibits creativity—sometimes; inhibits my recognizing it as well. ${ }^{190}$

If my learning objectives for the assignment or examination, as reflected in the rubric, are narrow ones, then creativity may be stifled. ${ }^{191}$

\section{Rubrics Promote Superficial Thinking: Death of Thought Process}

The increasing use of rubrics to evaluate legal analytical writing decreases students' ability to practice critical thinking skills. Studies reveal that detailed and frequent evaluations of a student's accomplishments are counterproductive. ${ }^{192}$ When rubrics are used for each assessment, students decrease engagement in the thought process and become obsessed with the outcome and having the "correct answer." 193 Students are less interested in the assignment and become less perseverant in the face of failure. ${ }^{194}$ In failure of the rubric, students tend to attribute results to innate ability beyond a student's control. ${ }^{195}$

The decline of thought processing is inherent to rubric-based grading and cannot be solved by a new rubric: "[Rubrics] boil a messy process down to four to six rows of nice, neat, organized little boxes . . . They seduce us with their appearance of simplicity and objectivity and then secure their place in our repertoire of assessment techniques with their claim to help us clarify our goals." 196

It follows, then, that providing students access to the rubric ahead of the writing assignment, so that students know exactly how their writing will be evaluated, compromises the quality of teaching and standardizes learning. The availability of the rubric in advance is nothing more than

187. Infra App. 1, Survey Results, at 755.

188. Id.

189. Id.

190. Id. at 753 .

191. Id. at 754 .

192. See generally Terence J. Crooks, The Impact of Classroom Evaluation Practices on Students, 58 REV. EDU. RES. 438 (1988).

193. Id. at $455-56$.

194. Id.

195. Id. at 468; DWECK, supra note 5, at 193-201.

196. WILSON, supra note 21, at 2. 
"teaching to the test" and belies the very purpose of law education: critical thinking. ${ }^{197}$

Educational psychology studies reveal that when students relentlessly focus attention on how well they are doing, they become less engaged with what they are doing. ${ }^{198}$ One survey responder does not provide rubrics in advance for this reason:

I don't give the rubric to my students ahead of time. The rubric is not for students, it is for me, to ensure the same reflective evaluation of every paper, based on the same criteria. It helps increase the likelihood I will be consistent in grading. I find repugnant the idea of giving a student a rubric, so they can conform their work to a paintby-numbers-style template. That would stifle creativity, inhibit independent problem-solving, and encourage intellectual lazinessnone of which I support! ${ }^{199}$

Increasing and steady use of rubrics in legal education produces lawyers who are unable to function unless every item is spelled out in a grid and assigned a point value. Confidence in thinking and writing skills is reduced and students become unwilling to take risks with writing. The consequences for legal practice are dire: after law school new graduates will be unable to perform competently in practice. Judges (that is, the new "graders") do not provide rubrics for writing briefs.

Meeting the criteria of rubrics contributes to a fixed mindset, that is, a tendency to attribute results to innate ability beyond a student's control. ${ }^{200}$

\section{E. Rubrics Do Not Improve Letter Grading}

Proponents of rubrics opine that rubrics are a superior assessment tool, arguing that a $\mathrm{B}+$ at the top of a paper provides little information about the quality of the paper, whereas a rubric provides more detailed information based on multiple criteria. ${ }^{201}$ Assignment of grades generally reduces students' interest in the overall learning, however, and rubrics intensify the disinterest. ${ }^{202}$ Research reveals that students become less interested in things they are instructed to do (that is, writing a paper in a manner to simply check off the boxes on the rubric or grade sheet provided to them in advance $)^{203}$ and that rubrics tend to reduce students' preference

197. See generally id.

198. Alfie Kohn, The Trouble with Rubrics, 95 ENG. J. 12, 14 (2006).

199. Infra App. 1, Survey Results, at 758.

200. See DWECK, supra note 5, passim.

201. Alfie Kohn, From Degrading to De-Grading, High ScH. MAG., Mar. 1999, at 38.

202. Id.

203. Alfie KoHn, Punished By REWARds 39 (1993). 
for challenging tasks. ${ }^{204}$ "The more pressure to get an A, the less inclination to truly challenge oneself. Thus, students who cut corners may not be lazy so much as rational; they are adapting to an environment where good grades, not intellectual exploration, are what count." 205

Grades based on rubrics also tend to reduce the quality of students' thinking. In one study, students expecting quantitative grades were "significantly less creative than those who received qualitative feedback but no grades." ${ }^{206}$ Conversely, students performed best when they received comments rather than numerical scores. ${ }^{207}$ Alfie Kohn cites two other studies that also suggest that the expectation of grades inhibits students' ability to learn (that is, understand) the material. ${ }^{208}$

The negative effects of grading are exacerbated in "curved" environments. Without engaging in a full discourse on the value (or lack thereof) of curved grading in law school, grades that fall into a "normal" distribution do not indicate successful learning but rather failure: to teach, to test well, and to have any influence at all on the intellectual lives of students. ${ }^{209}$ With a "failure model," students become victims of a fixed mindset and learning stagnates. Given the prevalence of curves in law school grading, law students are likely to experience feelings of failure as a result of being graded on a curve. ${ }^{210}$

And in light of both a volatile legal employment market and the importance employers attribute to grade point averages, law students may

204. See id. at 140 (““[A]ny contingent payment system tends to undermine intrinsic motivation[.]"”) (citation omitted).

205. Joseph Holtgreive, Too Smart to Fail?, InSIDE HigHER ED (Aug. 16, 2016), https://www.insidehighered.com/views/2016/08/16/students-focus-too-much-grades-detriment-

learning-essay [https://perma.cc/GP8Y-6GJS] ("Focusing on learning creates a direct relationship between input and outcome: the more effort they invest, the greater the opportunity to learn. However, the calculus of competence is fundamentally different depending on how you define success. When the goal is to be smart, the formula is reduced to maximizing grades while minimizing effort. When the goal is to learn, the formula becomes about maximizing learning while optimizing effort.").

206. Alfie Kohn, The Schools Our Children Deserve: Moving Beyond Traditional ClassRoOMS AND “TOUgher STANDARDS” 42 (1999).

207. See, e.g., R. Butler \& M. Nisan, Effects of No Feedback, Task-Related Comments, and Grades on Intrinsic Motivation and Performance, 78 J. EDUC. PsychoL. 210 (1986); R. Butler, Enhancing and Undermining Intrinsic Motivation: The Effects of Task-Involving and Ego-Involving Evaluation on Interest and Performance, 58 BRITISH J. EDUC. PsYCHOL. 1 (1988); R.I. Butler, TaskInvolving and Ego-Involving Properties of Evaluation: Effects of Different Feedback Conditions on Motivational Perceptions, Interest, and Performance, 79 J. EDUC. PSYCHOL. 474 (1987).

208. See generally E.M. Anderman \& J. Johnston, Television News in the Classroom: What Are Adolescents Learning?, 13 J. AdOLESCENT RES. 73 (1998); W.S. Grolnick \& R.M. Ryan, Autonomy in Children's Learning: An Experimental and Individual Difference Investigation, 52 J. PERSONALITY \& SOC. PSYCHOL. 890 (1987).

209. Ohmer Milton, Howard R. Pollio \& James A. Eison, Making Sense of College GRADES 225 (1986).

210. Learning v. achieving: they are opposites. Alfie Kohn, The Trouble with Rubrics, 95 ENG. J. 12, 14 (2006) (citation omitted). 
well experience more pressure to achieve good grades than does any other educational demographic.

\section{CONCLUSION}

Because the purpose of legal education is to produce highly competent critical thinkers for law practice, we should abandon rubrics for assessment of writing except to inform the organization of our own evaluation criteria. Our best practices for assessment and evaluation require that we use rubrics sparingly and only in the assignment design process for teaching ideas to effectuate our teaching goals and learning outcomes.

Professors assigning legal analytical writing projects rely on rubrics to standardize thinking about student assignments. Although we may benefit from consulting a rubric briefly in the early stages of designing a curriculum in order to think about various criteria, the rubric should not play a constructive role in evaluation of writing. Instead, we should focus assessment of legal analytical writing on the recursivity of the writing process: assign and allow practice, and offer continuous feedback.

We are highly knowledgeable and more than competent to activate our own instincts to provide substantive feedback to students on their written analytical work. Law professors need not repress our own metacognitive abilities in order to evaluate students successfully at the beginning of their learning process.

Feedback on legal analytical writing should be designed to increase metacognition and self-regulation so that students can proactively use their own strengths and efforts to learn and set goals and task-related strategies. To that extent, our narrative, descriptive, holistic feedback on student work that identifies areas of improvement and provides examples is the most useful teaching tool that translates to a learning outcome. Good feedback practice is characterized by the following seven principles:

1. clarifies what good performance is (goals, criteria, expected standards);

2. facilitates the development of self-assessment (reflection) in learning;

3. delivers high quality information to students about their learning;

4. encourages teacher and peer dialogue around learning;

5. encourages positive motivational beliefs and self-esteem; 
6. provides opportunities to close the gap between current and desired performance;

7. provides information to teachers that can be used to help shape the teaching. ${ }^{211}$

Principles of good feedback are best achieved by ongoing communication and through a shared vocabulary for talking about and rendering judgments about writing. ${ }^{212}$ Written legal analysis is the product of the particular community of the classroom, including the professor and the students at any given time.

Christine M. Dawson describes the oral feedback process as "engaging students in authentic conversations." ${ }^{213}$ In the classroom, and later in practice, oral feedback provides the best environment for observations, questions, clarifications, and responses. ${ }^{214}$ To foster authentic student discussions about writing, Dawson recommends a lowstakes "Quaker Share," where students read aloud part of their written work in the classroom to hear the sounds of their writing and the writing of their peers. ${ }^{215}$ Students are not permitted to comment or provide a response, but the peer experience increases confidence to enter into conversations about their writing. ${ }^{216}$

Our holistic feedback should include oral collaboration with both peers and the professor to encourage important development. We can achieve the goal of authentic conversations by undertaking ungraded, live review of student drafts prior to submitting final assignments.

The oft-raised concern of subjectivity of holistic grading in written form can be offset by anonymous evaluation, at least at the outset of learning the craft of the legal analytical process. As students begin to develop their unique voice, the professor may recognize the writer's style. But at the point of fine-tuning, the evaluation process is more intimate, and the professor will work with the student at their strength level.

Finally, an institutional buy-in to writing across the curriculum will improve evaluation of legal analytical writing despite differing criteria for each professor. Students learn ultimately to write for their reader and to employ clarity in the expression of analytical content. Assessment is

211. Nicol \& MacFarlane-Dick, supra note 130, at 205.

212. Chris W. Gallagher \& ERIC D. Turley, Our Better Judgment: Teacher LEADERSHIP FOR WRITING ASSESSMENT 89-90 (2012).

213. See generally Christine M. Dawson, Beyond Checklists and Rubrics: Engaging Students in Authentic Conversations About Their Writing, 98 ENG. J. 66 (2009).

214. Id. at 66.

215. Id. at 67 .

216. Id. at $67-68$. 
[Vol. 41:713

degraded, and clarity of thought and meaning are lost when writing by and to the numbers. 


\section{Appendix 1}

\section{Survey Results}

2. Ignoring the objectivity imposed by rubrics, is the work product by which you primarily evaluate...

\begin{tabular}{|r|l|c|c|}
\hline$\#$ & Answer & Response & \% \\
\hline 1 & Inherently subjective & 175 & $93 \%$ \\
\hline 2 & Inherently objective & 14 & $7 \%$ \\
\hline & Total & 189 & $100 \%$ \\
\hline
\end{tabular}

3. Do you use rubrics to grade your students?

\begin{tabular}{|c|l|c|c|}
\hline$\#$ & Answer & Response & \% \\
\hline 1 & Yes & 140 & $80 \%$ \\
\hline 2 & No & 34 & $20 \%$ \\
\hline & Total & 174 & $100 \%$ \\
\hline
\end{tabular}

4. Does your institution or department require that you use rubrics to assign grades?

\begin{tabular}{|r|l|c|c|}
\hline$\#$ & Answer & Response & $\%$ \\
\hline 1 & Yes, for all assignments/exams & 10 & $7 \%$ \\
\hline 2 & $\begin{array}{l}\text { Yes, but only for some } \\
\text { assignments/exams }\end{array}$ & 8 & $6 \%$ \\
\hline 3 & No, rubrics are not required & 126 & $88 \%$ \\
\hline 4 & No, rubrics are forbidden & 0 & $0 \%$ \\
\hline
\end{tabular}




\begin{tabular}{|l|l|l|l|}
\hline Total & 144 & $100 \%$ \\
\hline
\end{tabular}

5. With which of the following statements do you agree?

\begin{tabular}{|c|c|c|c|}
\hline \# & Answer & Response & $\%$ \\
\hline 1 & $\begin{array}{l}\text { If it were my decision, I would use } \\
\text { rubrics to evaluate all } \\
\text { assignments/exams }\end{array}$ & 25 & $18 \%$ \\
\hline 2 & $\begin{array}{l}\text { If it were my decision, I would use } \\
\text { rubrics to evaluate some } \\
\text { assignments/exams }\end{array}$ & 39 & $28 \%$ \\
\hline 3 & $\begin{array}{l}\text { Even if it were my decision, I would } \\
\text { still not use rubrics to evaluate any } \\
\text { assignments/exams }\end{array}$ & 1 & $1 \%$ \\
\hline 4 & $\begin{array}{l}\text { N/A (the decision to use rubrics is } \\
\text { mine to make) }\end{array}$ & 74 & $53 \%$ \\
\hline & Total & 139 & $100 \%$ \\
\hline
\end{tabular}

6. Do you, personally, create your own rubrics?

\begin{tabular}{|c|l|c|c|}
\hline$\#$ & Answer & Response & \% \\
\hline 1 & Yes & 131 & $95 \%$ \\
\hline 2 & No & 7 & $5 \%$ \\
\hline & Total & 138 & $100 \%$ \\
\hline
\end{tabular}

7. If you do not create your own rubrics, are you provided any training or guidance on how to use your rubrics?

\begin{tabular}{|c|l|c|c|}
\hline$\#$ & Answer & Response & \% \\
\hline 1 & Yes & 5 & $5 \%$ \\
\hline 2 & No & 6 & $6 \%$ \\
\hline
\end{tabular}




\begin{tabular}{|l|l|c|c|}
\hline 3 & N/A (I create my own rubrics) & 82 & $88 \%$ \\
\hline & Total & 93 & $100 \%$ \\
\hline
\end{tabular}

8. If you receive training or guidance on how to use your rubrics, how much time do you generally spend on such training or guidance?

\begin{tabular}{|c|l|c|c|}
\hline$\#$ & Answer & Response & \% \\
\hline 1 & $1-3$ hours & 18 & $78 \%$ \\
\hline 2 & $4-6$ hours & 4 & $17 \%$ \\
\hline 3 & $7-10$ hours & 1 & $4 \%$ \\
\hline 4 & $10+$ hours & 0 & $0 \%$ \\
\hline & Total & 23 & $100 \%$ \\
\hline
\end{tabular}

9. How conducive do you believe rubric-based grading is to helping students develop strong lawyering skills (e.g., persuasive writing, critical thinking?)

\begin{tabular}{|r|l|c|c|}
\hline$\#$ & Answer & Response & \% \\
\hline 1 & $\begin{array}{l}\text { Very conducive - rubric-based } \\
\text { grading facilitates strong } \\
\text { lawyering skills }\end{array}$ & 100 & $23 \%$ \\
\hline 2 & $\begin{array}{l}\text { Somewhat conducive - there } \\
\text { are certain attributes of great } \\
\text { lawyering skills that cannot be } \\
\text { fully accounted for on a rubric }\end{array}$ & $\begin{array}{l}\text { Not conducive - rubric-based } \\
\text { grading has a negative effect on } \\
\text { the development of strong } \\
\text { lawyering skills }\end{array}$ & $13 \%$ \\
\hline & Total & $3 \%$ \\
\hline
\end{tabular}

10. With which of the following statements do you most agree? 
[Vol. 41:713

\begin{tabular}{|c|l|c|c|}
\hline$\#$ & Answer & Response & \% \\
\hline 1 & $\begin{array}{l}\text { In general, I believe rubric-based } \\
\text { grades tend to be higher than the } \\
\text { grades I otherwise subjectively } \\
\text { believe are accurate }\end{array}$ & $13 \%$ \\
\hline 2 & $\begin{array}{l}\text { In general, I believe rubric-based } \\
\text { grades tend to be the same as the } \\
\text { grades I otherwise subjectively } \\
\text { believe are accurate }\end{array}$ & 110 & $82 \%$ \\
\hline 3 & $\begin{array}{l}\text { In general, I believe rubric-based } \\
\text { grades tend to be lower than the } \\
\text { grades I otherwise subjectively } \\
\text { believe are accurate }\end{array}$ & 114 & $10 \%$ \\
\hline & \begin{tabular}{l} 
Total \\
\hline
\end{tabular}
\end{tabular}

11. Assuming that you are not able to exercise any discretion to modify rubric-based grades, with which of the following statements do you most agree? For a given assignment/exam (completed by $100 \%$ of the students in the class), I generally agree with the rubric-based grade for:

\begin{tabular}{|r|l|c|c|}
\hline$\#$ & Answer & Response & $\%$ \\
\hline 1 & $100 \%$ of my students' scores. & 25 & $20 \%$ \\
\hline 2 & $\begin{array}{l}80-99 \% \% \text { of my students' } \\
\text { scores. }\end{array}$ & 65 & $52 \%$ \\
\hline 3 & $60-79 \%$ of my students' scores. & 22 & $18 \%$ \\
\hline 4 & $30-59 \%$ of my students' scores. & 8 & $6 \%$ \\
\hline 5 & $10-29 \%$ of my students' scores. & 2 & $2 \%$ \\
\hline 6 & $\begin{array}{l}\text { Less than } 10 \% \text { of my students' } \\
\text { scores. }\end{array}$ & 3 & $2 \%$ \\
\hline & Total & 125 & $100 \%$ \\
\hline
\end{tabular}


12. When I disagree with a rubric-based grade, it is generally by:

\begin{tabular}{|c|l|c|c|}
\hline$\#$ & Answer & Response & \% \\
\hline 1 & $5 \%$ & 32 & $25 \%$ \\
\hline 2 & $5-10 \%$ & 44 & $35 \%$ \\
\hline 3 & $11-15 \%$ & 8 & $6 \%$ \\
\hline 4 & $15 \%$ & 3 & $2 \%$ \\
\hline 5 & $\begin{array}{l}\text { I rarely, if ever, disagree with a } \\
\text { rubric-based grade }\end{array}$ & 39 & $31 \%$ \\
\hline & Total & 126 & $100 \%$ \\
\hline
\end{tabular}

13. In which of the following ways, if any, do you believe rubric-based grading is beneficial to law students (Please select all that apply)

\begin{tabular}{|r|l|c|c|}
\hline$\#$ & Answer & Response & \% \\
\hline 1 & $\begin{array}{l}\text { Facilitates consistency of } \\
\text { grades }\end{array}$ & 55 & $42 \%$ \\
\hline 2 & Facilitates validity grades & 61 & $46 \%$ \\
\hline 3 & $\begin{array}{l}\text { Easier for students to } \\
\text { understand my expectations }\end{array}$ & 44 & $33 \%$ \\
\hline 4 & $\begin{array}{l}\text { Other (if more than one, please } \\
\text { separate with semi-colon): }\end{array}$ & & $27 \%$ \\
\hline
\end{tabular}

\section{Expanded responses:}

Allows the assessment exercise to do double-duty as a feedback exercise. By sharing the rubric ahead of time, then by articulating how each student's work conforms or departs from each part of the rubric, students better learn their individual strengths and weaknesses.

Facilitates both validity of grades and understanding of expectations.

All of the above. And, rubrics facilitate my developing consonant teaching and testing. 
Facilitates consistency, facilitates validity, helps students understand my expectations, allows students to develop reflective, selfassessment skills

All of the reasons listed here are good ones. Btw, I use rubrics for each assignment/examination on a specified point scale and then compile the grades before curving for the course grade.

Useful for initial sorting; identifying whether students meet standardized criteria

Ensures that I examine work product in a consistent way

facilitates grade validity; students better understand expectations

I believe all of these statements are true.

All three of the choices

Gives students a sense of both expectations and comfort

I think all of the above can apply; that said, my rubrics reflect my priorities in class and indicate how I'm not hiding the ball — that I mean what I say.

Allows students to begin developing their own checklists; to understand the value of having and applying standards; helps students prioritize; and makes it easier for my students to understand my expectations

Easier to understand expectations and thus facilitates most important feedback - personal conferences

I use rubrics as a starting point - to indicate what I am looking for (they are only useful if you hand them out before the assignment is due). Once I grade, I may need to adjust the scores. Rubrics can be helpful for consistency, but they are not perfect

All of the above; provides students with extensive feedback; reduces student concerns and complaints about grading; enhances student perceptions that grading was fair

Helps constrain my subjectivity by allocating weight among potential areas of performance

provides a structure for students to do self-evaluation and assessment

Provides more specific context to what is being measured and what demonstrates various levels of competence.

Gives them a sense of fairness in an otherwise subjective process

Gives clear feedback

If some students make arguments that I didn't anticipate but are valid, I add them to the rubric for consistency's sake. 
14. In which of the following ways, if any, do you believe rubric-based grading is detrimental to law students?

\begin{tabular}{|c|l|c|c|}
\hline & Answer & Response & $\%$ \\
\hline 1 & $\begin{array}{l}\text { Shifts emphasis of } \\
\text { assignments/exams away from } \\
\text { learning }\end{array}$ & 24 & $24 \%$ \\
\hline 2 & Inhibits/discourages creativity & 26 & $27 \%$ \\
\hline 3 & $\begin{array}{l}\text { Inhibits/discourages critical } \\
\text { thinking }\end{array}$ & 9 & $9 \%$ \\
\hline 4 & $\begin{array}{l}\text { Inhibits/discourages } \\
\text { persuasiveness }\end{array}$ & 44 & $4 \%$ \\
\hline 5 & $\begin{array}{l}\text { Other (if more than one, please } \\
\text { separate with semi-colon): }\end{array}$ & 4 & \\
\hline
\end{tabular}

Expanded responses:

Inhibits creativity - sometimes; inhibits my recognizing it as well

I suppose I don't know what you mean by a "rubric." To me a rubric builds in flexibility to evaluate. It's not a rigid system. If one makes it a rigid system, that leads to all kinds of bad stuff.

Students focus too much on the point categories, instead of the "big picture."

Since I create my own rubrics I can account for creativity, critical thinking, persuasiveness.

Encourages students to approach assignments in a paint-bynumbers manner

I don't think rubrics inhibit/discourage these things - I think rubrics just inherently don't address those skills.

May make students spend less time understanding other feedback on their assignments.

None 
Students can become too focused on the individual components rather than the overall scope and organization of the assignment.

If my learning objectives for the assignment or examination, as reflected in the rubric, are narrow ones, then creativity may be stifled.

I don't think it is detrimental if used properly.

Rubric-based grading masks the inherently subjective nature of grading written product

It's not easy to determine ahead of time all of the things that you will catch or care about on a student work, and I like to give the students a "working rubric" so they have a sense of what to expect from me.

Students can focus too much on certain categories without realizing that those categories likely impact other categories on the rubric as well.

Having a bad rubric is detrimental to law students.

Shifts emphasis of assignments away from learning; inhibits critical thinking; focuses students on points

Allows them to rely, perhaps too significantly, on the rubric.

Categories' relative values are pre-set, but there are times when a ceiling score proves too low for the quality of work done.

Could also be all of the above. Students use rubrics to focus on points, not content. I don't use rubrics during the first semester.

Doesn't always focus accurately on the whole paper. But this could be my design error rather than a disadvantage to using rubrics.

Leads students to believe that legal writing assignment can be assessed solely by means of objective criteria, when in fact, there is necessarily a subjective component to grading these assignments. May occasionally lead to nit-picking over scores assigned to particular criteria.

rubrics can themselves limit student focus - but don't have to none of the above. I don't feel It inhibits my students.

Students often focus on the "points" per section on the rubric, as opposed to the entire picture. I use rubrics to show where students need 
improvement, but you must go an additional step and get students to focus on the "big picture."

none if the rubric is created and used correctly

It can be difficult for a rubric to capture the overall impact of a paper or particularly good expression, that "je ne sais quoi."

Rubric grading can miss quality conveyed by a cohesive, overall reading of the document.

Students inaccurately assume the rubric is the sum total of all that could be learned or demonstrated.

I use a rubric in only one aspect of my teaching. Otherwise I believe lawyering is a holistic activity that must be graded more holistically than a rubric by itself allows.

Assumes "one size fits all" categories and strengths/weaknesses for all students. Gives students a snapshot of their projects when looking INTO the paper is necessary to see where they had specific issues or successes - even breaking the rubric into parts is not always enough of a breakdown.

Not detrimental but irrelevant-students seem too overloaded to look at the rubric when writing an exam memo or brief.

Too vague; hard for students to know exactly what to do to improve.

Rubrics may not cover the bleeding of errors between categories; rubrics may not cover all aspects of effective communication

If adhered to slavishly, rubrics can overstate or understate grades. If rubric is ill-designed, it's a mess and invalid. Sometimes it is necessary to read a representative sample of answers to be sure rubric is properly calibrated and covers what the students see. Advance release is thus complicated and might limit their approach. 
15. In regard to your answers to (9) and (10) above, with which of the following statements do you most agree?

\begin{tabular}{|r|l|c|c|}
\hline$\#$ & Answer & Response & $\mathbf{\%}$ \\
\hline 1 & $\begin{array}{l}\text { The benefits of rubric-based } \\
\text { grading outweigh the } \\
\text { detriments. }\end{array}$ & 105 & $83 \%$ \\
\hline 2 & $\begin{array}{l}\text { The detriments of rubric-based } \\
\text { grading outweigh the benefits. }\end{array}$ & 7 & $6 \%$ \\
\hline 3 & It's an even trade-off. & 14 & $11 \%$ \\
\hline & Total & 126 & $100 \%$ \\
\hline
\end{tabular}

16. Understanding that this survey cannot fully account for all opinions about rubric-based grading, please feel free to share any additional opinions, information, etc. relating to rubric-based grading.

I don't want to say that I hate rubrics, but I feel so constrained by them. I do hate spending so much time dithering between a 20 or a 21 . As a result, I often go to a .5 in between. ie. 20.5. Rubrics waste so much time in grading and they take away from commenting. Rubrics take away from the big picture holistic grade. All the students do is focus on the number and compare numbers. Does not facilitate learning. Ok, I do hate rubrics!

It keeps me focused \& lets students know what is expected of them. I hand out the rubrics ahead of time $\&$ students really appreciate that.

I am a professional educator- I have undergrad and graduate degrees in education, and I taught high school for several years before attending law school. Rubrics are essential to learning because they externalize our expectations. However, rubrics are not effective without feedback or if we don't share them with students. Learning should be transparent and we should not hide our expectations and then hold our students accountable for meeting them. Law school is not so "special" that students should just have to figure it out on their own and be penalized for not getting it right the first time. 
Rubrics are beneficial if the teacher provides the rubric to students before completion of the assignment by the student so the student understands the teacher's expectations for the assignment.

I distribute the rubrics for students to review before turning in assignments, I've found that functions as a good final checklist for them.

When the rubric is too far from my subjective overall assessment (say over 5\% difference), I tweak the rubric to ensure it accurately assesses what I am looking for in the macro and micro execution of the work. I've been tweaking some of my rubrics for more than four years, and one I changed again this year after seven years.

It is critical to modify a rubric for each assignment. Have some means to show a student where they fall on a range of scores/assessments. Rubric should be easy to understand.

At my school, there are no required rubrics or even the requirement of a rubric. Once I develop a rubric for a particular assignment or exam essay question, I test it against a subset of the submissions. I then adjust the rubric if it does not appear to be an accurate assessment of the work product or if in developing the rubric I did not account adequately for an alternative means of addressing the issues.

I grade assignments (oral, written, and hybrid) and examinations using rubrics. The rubrics track the learning objectives I have set for the students. I don't know how I would assess student performance (attainment of those objectives) fairly without them. Btw, for some reason, the next few questions seem to assume I do not use rubrics. I will leave the answers blank.

I use both subjective and objective assessment in every class. Correlation is very high between the two scores with approximately $5 \%$ of students showing variation of greater than 1 full letter grade. I use the rubric for my initial pass on the subjective grading but provide for possible points outside the rubric either for original arguments, novel but permissible inferences from the facts leading to novel but valid arguments. If I stayed entirely with my rubric, it would harm excellent students. There is also a problem of subjectivity even with the rubricstudents may touch on the correct issues, state correct rules, but holistically demonstrate that they have absolutely no clue what they are doing. A rubric would score that type of answer high. 
I use rubrics to help me examine work product in a similar way. I also use a "gut check" subjective grade to compare to any rubricgenerated grade

I have started experimenting with asking the class coming up with a rubric - it's one more opportunity to reinforce what I'm trying to teach (and a way for me to learn what they've heard). We've worked on a broad outline together, and then I've broken them up into groups to create, on their own, a detailed rubric for their assigned sections. I then put them together (with my edits/supplements).

Rubric-based grading is only as good as the rubric. For example, a rubric says award one point for every element of the rule listed is much different than a rubric that says award 10 points for a rule statement that fully states the rule and all exceptions, award 8 points for a rule statement that fully states the rule but no exceptions, and so forth. In the latter, the rule statement needs to be well written and coherent to get all 10 points. In the former, random words on the page will garner all the points because the rubric says to award a point if the words are there regardless of how they are arranged on the page.

I don't give the rubric to my students ahead of time. The rubric is not for students, it is for me, to ensure the same reflective evaluation of every paper, based on the same criteria. It helps increase the likelihood I will be consistent in grading. I find repugnant the idea of giving a student a rubric, so they can conform their work to a paint-by-numbersstyle template. That would stifle creativity, inhibit independent problem-solving, and encourage intellectual laziness - none of which I support!

Students appreciate knowing exactly what I'm grading for on each assignment. I have never had a complaint about my rubric use, which is almost $100 \%$.

I think you've captured well the idea that rubrics are a trade-off and that there's value in graining faculty how to write and administer them. In my experience, 1Ls appreciate the sense of control they get from a rubric, especially if they were taught with rubrics before law school. In scholarly writing we use a "soft rubric," mostly to help students understand our expectations, but it's not refined enough to really justify the what makes one research paper more persuasive or publishable than another. I don't think trying to mandate a "hard rubric" 
for scholarly writing would improve the learning process because so much of what makes a research paper particularly effective is how well the author implements the "art" of rhetoric.

Makes it easier to see in what way a student has missed the boat (conclusory, missed issues, etc.)

I appreciate rubric grading for two reasons: First, it reduces or eliminates the reader bias I experience when reading really poorly worded writing rife with grammar, usage, spelling, citation, or general English language mistakes. It allows me to give fair grades on the separate criteria of the assignment without failing or tearing the student down solely because the writing is painful to read. Second, I hand out each rubric ahead of time and instruct the students to read it and apply it, so that they can know my exact expectations, and use the rubric as a self-guided checklist on how to complete the assignment.

It's essential to create rubrics that include relevant categories for critical thinking, creativity, and the like. It's also essential that rubrics allow room for subjectivity. E.g., rubrics should not include "points," and instead should indicate "above average," "average," "below average" for each category.

They have become a necessary evil in the world of outcomes assessment.

While I use rubrics to give feedback, the grade isn't completely tied to that rubric. For instance, the students might have a rubric that tells them a case illustration must begin with the principle of the case and then give facts and then give reasoning and then give the court's conclusion. And I will comment on each of these things. But there isn't a score associated with each of these things. Instead, I'll give a score for the overall legal analysis. Because I felt I misunderstood when I hit the questions about grading, I didn't answer many of those questions.

I have taught classes in which the rubric was provided to establish superiority; however, individual adjuncts graded differently even with a uniform rubric. If the adjunct does not value citation skills, then the points are awarded without regard to the quality of work done. If the adjunct has not adopted the same brief-writing structure, then failure to comply may not result in a lower score. Also, I have worked in a program that assigns so many points to formatting and highly subjective categories like "Professionalism" that there is a floor that gives "B" grades to students who do not demonstrate efforts to apply critical 
analysis. I use rubrics and like them, but see cases in which they are of average utility. Note: I do not understand Q17. I do use rubrics.

Sometimes I use rubrics, and sometimes I don't. I rarely use them during the first semester. My rubrics are of my own creation and thus allot the most points to the writing and analytical components of the assignments, plus a substantial amount to how clearly the info was conveyed. Frankly, the rubric doesn't really help the student much, except to see where they stand on big-ticket items. The rubric sometimes benefits me by way of 1 ) demonstrating to the students that I don't grade based on how I "feel" about a paper, and 2) validating the distinction between good papers and not-so good papers. A score of $0 / 10$ in citation also sends a very clear message about citation abilities.

Rubrics are particularly helpful for managing large sections of students

I use the rubrics to get me to the base grade and to be as objective as possible, but I allow myself some wiggle room if I feel the rubricgrade does not properly reflect the level of the paper. I also sometimes assign a grade based on a first or second read, and then use the rubricgrade to support my initial grade. I review/grade some assignments on a check, check plus, check minus (sometimes check plus plus, check/plus) standard and the rubric helps me verify that I am consistent in assigning a correct broad base grade.

My rubrics are not detailed. The categories are generally broad. I find it difficult to use detailed rubrics, and I find that they can be a bit rigid.

Although I use a very detailed rubric for my assignments, I always pencil in a "gut-level" letter grade ( e.g. A-/B+ or B) before calculating the numerical total on the rubric. Over time, I have fine-tuned the points on the rubric so that the numerical score generally is consistent with my gut-level letter grade. If there is a discrepancy, then I reread the paper and review the numerical scores to try to determine which grade is off. If I still am convinced that the gut-level grade is accurate, then I start tweaking some of the numbers so that they add up to a score consistent my gut grade.

I direct an adjunct program, so I prepare rubrics for everyone. We use them so that we have consistent criteria on which to base our assessment of assignments and some consistency among sections in 
terms of what has the most weight for a particular assignment. We provide students with a list of evaluation criteria along with the assignment, but we do not share the points allocated to each and to not give them a rubric with the grade (we use ecomments and end comments). And we use them flexibly. We try to have an overall sense of a paper (this "feels like a B") and then compare that to the points on the rubric. We make adjustments if the two don't agree.

I think the strengths of rubrics lies in their drafting. A well-drafted rubric can target skill and substance to be learned through a project and act as a guide for students. A less well-drafted rubric can overwhelm students or do any of the detrimental things suggested by this survey. To help students use rubrics to their advantage, we also need to educate students about the rubric's function.

Creating the rubrics helps me to concretely define what core skills I will be evaluating in the assignment \& thus I am better able to communicate them to my students. The rubrics also keep my review more objective, I tend not to get so carried away with good writing that I ignore the quality of the substantive arguments. Finally, use of a detailed rubric helps me to identify areas where many students might be struggling, which then allows me to "re-teach" that lesson area to my students through subsequent assignments.

Rubrics allow me to justify why I gave a student a particular grade and ensure that I apply the same standards to all students.

I find it really takes away the students' perception of subjective grading. I have received far fewer complaints/questions about the grades once I started using a rubric.

I have started making my students create their rubrics as a class (with my guidance).

Those completing the survey may have different views on what "rubric-based grading" means. Some rubrics are very rigid and account for each part of the analysis substantively. Others serve as a tool to grade more holistically. I think that's an important distinction to interpret the survey results and make them meaningful. While I use grading rubrics, they serve merely as a guide for students while drafting and editing, and they serve as a means to provide notice to students for 
what they will be graded on eventually. I grade more holistically, however, even with the use of the rubrics.

I think it's possible to incorporate/retain some holistic aspects of grading when using a rubric. I like rubrics because they keep me honest in adhering to what I tell students in class and conferences. For example, if I stress that organization and analysis are more important than citation form in the earlier assignments, the rubric ensures I recognize that in my grading. If the rubric allocates $25 \%$ to organization and $5 \%$ to citation form, I award points in the following way: I determine (subjectively/holistically) that the paper's organization alone is the quality of a solid "B," for example, so I'll assign 21 points for that (85 $\mathrm{x} 25 \%$ ). And if I determine that the quality of the citation form would warrant a "D," I might assign 3 points to the citation form $(60 \times 5 \%)$. The detriment to this approach is that the student's score may not convey the dangers of poor citation in practice, but I gain the benefit of rewarding the student for focusing on the most important aspects of the paper and our class discussions. Students can also see those areas where they need most improvement. And if I sense that the score for any particular aspect of the paper is misleading, I'm still able to clarify and convey my concerns in my written comments.

I think rubrics have a place and - for me - are more helpful for law students just getting started. It focuses them in on the various pieces of the puzzle. By the time they are third years, I don't use rubrics any longer.

I mostly use rubrics for exam-grading out of a sense of fairnessso that the students know in advance what I will evaluate and so that I evaluate everyone as equally as possible along the same criteria. While I always have an exam or two that I need to go back and re-calibrate, I generally find that the rubric-based scores shake out fairly for grading purposes. As an aside, I'm actually more concerned about the mandatory numbers/restrictions on certain grades imposed by a curve. I find that using the grading curve is much more rigid than using the rubrics.

I don't believe a rubric is a substitute for conference -type feedback. I use it not for feedback to benefit the student primarily, but to help me maintain consistency in grading and refresh my recollection on trouble spots in the document. For the student, it provides only a 
snapshot and a starting point for discussion. Students are not permitted to keep the rubric, only to review it with me in my office.

Most students seem to try harder when they know the criteria against which they will be judged.

I use them for my own internal grading purposes on various (not all) assignments to ensure grading consistency. I also make extensive written comments, extensive enough that I rarely receive pushback from students on the grades I assign-I think they're more able to come to terms with a grade that's less than they'd prefer if their assignment is covered with my comments. I have on only very rare occasions needed to fall back on a rubric as part of a discussion with a student about their grade on an assignment.

My self-created rubrics are likely educationally invalid as rubrics - I roughly allocate a certain number of points to major aspects of a paper or exam answer, and subjectively assign within that number. I am comfortable with this system as a minor constraint on my potential reaction to hate or love a paper based on one aspect of it.

Rubrics can vary a lot and adjusted to be used in whatever ways seem most beneficial. It's not an all-or-nothing.

I find that strictly adhering to a rubric is sometimes a little formulaic. And, doing so can sometimes skew the grade (i.e. the student has technically hit all the points the rubric but it does not guarantee good quality). I prefer to use a rubric primarily to communicate to students my expectations. I must confess, though, that my actually use of the rubric is a little disingenuous. After reading the entire assignment, I come up with the grade on a holistic basis, then I go back to the rubric and plug in the numbers in the various parts of the rubric to arrive at my holistic grade.

I use rubrics only for a check - not as the main source of the grade - and it is a very loose rubric - so my answers may be completely unhelpful.

Lawyering is a blend of fact analysis and legal analysis. The sum is greater than the parts. I have yet to see a rubric that is able to reflect the rhetorical situation that occasioned the lawyering activity. If one can be invented I'd have a lot more faith. 
I think rubrics are too "one size fits all" and play into the "no child left behind" mindset. I prefer checklists that students can use as proofreading guides and that I can then use when I grade. Even when I create rubrics, each box within a category tends to look more like a checklist than anything else. The visual of being able to see where they land on a continuum is good for students, but a mini-line like that would be helpful without necessarily shoehorning comments into a canned rubric at the same time.

Huge effort up front to create the rubric; uncertain effect on student learning. Imaginary objectivity.

The ability of a rubric to facilitate a particular kind of learning depends on your flexibility in defining the rubric - for example, if you allocate points for originality of analysis, then you let more subjectivity back into the framework but students still know what to expect and where their work needs improvement.

I use detailed charts with lists/descriptions of what I am looking for. I fill in every box in the chart for the paper I am grading, to explain to the student whether they met my expectation there, and why. But I do not use the rubric to generate a grade or points. I use what I call a rubric to make sure that I am covering the same points with every student, but the rubric never dictates a grade.

Although they lend some internal consistency, they are not necessarily good tools for programmatic consistency, unless there is a mandated rubric. The creation of a rubric itself is filled with discretion in terms of what items to include, how they should be scored, the value of those items, etc.

My issue is not with the theory of rubric-based grading, but instead, with the rubrics we are forced to use. They have grown to be 56 pages long, and are overly cumbersome. Yet, many times the numerous categories and criteria do not seem to apply to what I want to say about the students' writing. I believe these lengthy rubrics are overwhelming and confusing to the students, and excessively timeconsuming for the instructors forced to use them.

Since I create and use my own rubrics I like them - and I even adapt them year-by-year. I would feel differently if I did not create the rubric.

We should be able to state learning objectives. Rubrics then reinforce those and have us measure what we think important. 
I don't use formal rubrics for my legal writing courses (objective and persuasive). I supplement my textbook with detailed handouts explaining my expectations for the shorter sections of memos and briefs (e.g., statement of facts, question presented, brief answer, summary of the argument). I base my written feedback on those handouts, which include checklists. I do wonder if checklists reduce student's critical thinking. While we discuss the reasons for drafting choices at length in class, students don't always absorb this information. When critiquing the discussion section of a memo or the argument section of a brief, I don't use rubrics. Again, based on the textbook, handouts, and in-class discussions I clearly describe my expectations regarding what makes an effective legal argument. My comments then parallel and reinforce these expectations. I don't believe that rubrics could reinforce my learning objectives as effectively as detailed written comments.

My final exam consists of 40 multiple-choice questions (weighted 2 points each) and 1 essay question. There is not a maximum number of points for the essay, so it's not weighted. I add the multiple-choice score with the raw score for the essay to arrive at a total. I use the total to assign the grades. Therefore, to the extent that I don't think the final grade is reflected by the rubric, it is because a student's multiple choice score might have pulled up the student's grade. In other words, I think the rubric reflects the essay score very well. But some students get higher grades than I would have assigned for the essay via the rubric because they might have performed better on the multiple-choice portion.

Use of rubrics tends to keep my focus on the same elements / criteria as I complete grading for a number of students, often over the course of a week or more. Use of rubrics tends to lead students, others and myself to view the grading as more of a data-driven science, when, in fact, considerable subjectivity still is involved. I fear that students focus on the terms of the rubric to comply for grading, rather than deeply absorb the flow and creativity / strategic aspects of legal analysis and writing.

17. Do you choose to not use rubrics, or are you not allowed to use rubrics (e.g., school/department forbids them)?

\begin{tabular}{|c|l|c|c|}
\hline$\#$ & Answer & Response & $\%$ \\
\hline 1 & I choose to not use rubrics & 24 & $92 \%$ \\
\hline
\end{tabular}




\begin{tabular}{|l|l|l|l|}
\hline 2 & I am not allowed to use rubrics & 2 & $8 \%$ \\
\hline & Total & 26 & $100 \%$ \\
\hline
\end{tabular}

18. For which of the following reasons, if any, do you choose to not use rubrics?

\begin{tabular}{|r|l|c|c|}
\hline$\#$ & Answer & Response & \% \\
\hline 1 & $\begin{array}{l}\text { Rubrics shifts emphasis of } \\
\text { assignments/exams away from } \\
\text { learning }\end{array}$ & 6 & $17 \%$ \\
\hline 2 & $\begin{array}{l}\text { Rubrics inhibit/discourage } \\
\text { creativity }\end{array}$ & 6 & $11 \%$ \\
\hline 3 & $\begin{array}{l}\text { Rubrics inhibit/discourage } \\
\text { critical thinking }\end{array}$ & 1 & $3 \%$ \\
\hline 4 & $\begin{array}{l}\text { Rubrics inhibit/discourage } \\
\text { persuasiveness }\end{array}$ & 25 & $71 \%$ \\
\hline 5 & $\begin{array}{l}\text { Other (if more than one, please } \\
\text { separate with semi-colon): }\end{array}$ & $6 \%$ \\
\hline
\end{tabular}

Expanded/Other Responses:

I don't believe rubrics allow me to give truly useful feedback; I don't believe rubrics provide accurate assessments of the quality of work, which is more holistic than is captured by a rubric.

I find that I cannot develop a rubric that really works and I end up forcing my opinion to fit the rubric instead of being able to use it to direct my opinion

I grade holistically. I believe that rubrics do not take into account the overall quality of the final product. I may have a student who gets citations wrong, but superior analytically to other students. I believe that I can assess the quality of work-A, B, C, D, or F-without a rubric.

All of the above 
I am a holistic grader. I find rubrics don't reflect how actual legal readers judge work product.

Lawyers and judges think of a brief or memo as a whole - not as a sum of its parts.

Have to use them.

I use rubrics

All of the above when misused; although rubrics supplied in advance can be used by students and teachers as a guide, when used to grade documents they cause all these problems and force teachers to lie to their students and modify the rubric to fit what was received!

I use rubrics.

Every piece written for each client is so different that it would be impossible to design a "rubric"

All of the above

Can be inaccurate if not properly designed

Not necessary for minor exercises

I am looking for persuasive writing and general points they need to make - a rubric limits me - sometimes they come up with something that it perfectly fine but would not fit into a rubric I created

I used a 100-point rubric for years. Then I graded the same set of papers with and without the rubric and the grades were exactly the same.

We must adhere to a curve. I cannot provide a rubric that correlates performance to a certain score, because the score will depend on the performance of other students.

Rubrics are too rigid in assigning relative value to the things I find important.

All of those reasons.

Rubrics add another step in commenting on papers. 
19. For which of the following reasons, if any, do you believe your school/department forbids the use of rubrics?

\begin{tabular}{|r|l|c|c|}
\hline$\#$ & Answer & Response & $\%$ \\
\hline 1 & $\begin{array}{l}\text { Rubrics shifts emphasis of } \\
\text { assignments/exams away from } \\
\text { learning }\end{array}$ & 1 & $4 \%$ \\
\hline 2 & $\begin{array}{l}\text { Rubrics inhibit/discourage } \\
\text { creativity }\end{array}$ & 1 & $8 \%$ \\
\hline 3 & $\begin{array}{l}\text { Rubrics inhibit/discourage } \\
\text { critical thinking }\end{array}$ & 1 & $4 \%$ \\
\hline 4 & $\begin{array}{l}\text { Rubrics inhibit/discourage } \\
\text { persuasiveness }\end{array}$ & $\begin{array}{l}\text { Other (if more than one, please } \\
\text { separate with semi-colon): }\end{array}$ & 24 \\
\hline
\end{tabular}

\section{Expanded responses:}

They are not forbidden at my school - many colleagues use them

My school does not forbid them. We are a directorless LRW program. Each professor decides for himself/herself whether to use a rubric. I choose not to use one. Other professors at my school use them.

My department allow them-I simply don't like them

I would never advocate for such a prohibition - it should be left to the discretion of the individual instructor.

It's my own choice.

Rubrics are not "forbidden." They simply do not work with a mandatory curve. We do use a detailed set of standards against which students are evaluated. They just aren't correlated to a certain score.

My school does not prohibit them-some in my department use them, but I don't. 


\section{Appendix 2}

\section{Rubrics}

\section{CONTRACTS II - Sample exam score sheet (based on spring 2006 exam)}

Multiple Choice Short Answer

( 7 points per question: $3 \mathrm{pts}$ for correct choice; $4 \mathrm{pts}$ for analysis)

1. (answer)

choice

5. (answer)

choice

analysis

analysis

2. (answer)

choice

6. (answer)

choice

analysis

analysis

3. (answer)

choice

7. (answer)

choice

analysis

analysis

4. (answer)

choice

8. (answer)

choice

analysis

analysis

Total:

Notes regarding the scoring of short answer questions:

1. Three of the seven points will be based on choosing the correct answer.

2. In some cases, I will give partial credit (up to four points, depending on the analysis) IF a second- best answer is chosen. I will determine which questions are eligible for partial credit (and which second-best answers qualify for partial credit) at the beginning of the grading process.

3. In order to receive full points for your analysis, it should reflect an accurate statement of the applicable rule and its application to the facts of the problem.

4. I may also give credit for an analysis that explains why the other choices are incorrect, but the preferable approach is to explain why the answer chosen is the best answer.

5. Your analysis should not exceed one paragraph in length. You will not lose points for exceeding this length, but you will lose valuable time.

Essay Question One (48 pts)

Applicability of UCC Article 2 (3 pts) 
Parol evidence rule/admissibility of course of dealing (UCC 1-205; 2-202; Nanakuli) (10 pts)

Third party beneficiary (R2d 302; Vogan) (7 pts)

Foreseeability and certainty of damages (Hadley; Redgrave) (8 pts)

Delegation of duties (UCC 2-210; Sally Beauty) (8 pts)

Delegation as repudiation/assurances (UCC 2-609)

Overall (8 pts)

depth (2 pts)

use of facts $(\overline{2 \mathrm{pts}})$

accuracy (2 pts)

support (2 pts)

Total:

Essay Question Two (24 pts)

Discussion of contract interpretation, Nanakuli and Taylor (12 pts)

Significance of merger clause (3 pts)

Accuracy (3 pts)

Depth/creativity (6 pts)

Total:

General criteria for scoring essay exam questions:

1. In order to receive full points, the answer must address all of the issues listed in the score sheet.

2. If an answer addresses an issue not listed in the score sheet, I will use my discretion in determining whether to allow extra points for it, depending on whether I believe the facts reasonably call for such a discussion, or whether such a discussion is beyond the scope of what the question asks you to address.

3. Depth: does the answer provide a statement of the applicable legal rule? How detailed is the statement of the rule, in particular the aspect of the rule that is at issue in the question? Does the discussion of the rule address policy or other considerations that we may have discussed in class?

4. Use of facts: does the answer apply the applicable legal rule to the facts? Does the answer consider how the inclusion of a particular fact in the question may affect the analysis? If the answer notes what is unstated in the question, is the omission relevant to the analysis (as opposed to speculating on omissions that raise new issues not called for in the question)? Does the answer provide a realistic conclusion in light of the facts that are stated in the question?

5. Accuracy: does the answer accurately discuss the law? Does it address the legal issues reasonably called for by the facts in the question? 
6. Support: (subsidiary to the other criteria, but also important) Does the answer cite to cases from the readings, the Restatement Second or UCC sections, or to examples from class discussion to support the legal points made? If the question raises an issue that is directly analogous to a case or example discussed in class, does the answer draw comparisons to that case or example? (Note: you need not memorize UCC or Restatement section numbers, but I do want to see that you know when the UCC applies (versus the common law or CISG)).

7. Depth/creativity: (this criterion comes up in some of the policy-oriented essay questions that you will see on my past exams) Does the answer thoughtfully and creatively address policy considerations relating to the question at hand? 
Name: Date: Class:

FIRST GRADE Informational Writing

\begin{tabular}{|c|c|c|c|c|}
\hline $\begin{array}{l}\text { Content \& } \\
\text { Form }\end{array}$ & \begin{tabular}{|l} 
Exceeds \\
Standards \\
4
\end{tabular} & $\begin{array}{l}\text { Meets } \\
\text { Standards } \\
3\end{array}$ & $\begin{array}{l}\text { Making Progress } \\
\text { Toward Standards } \\
2\end{array}$ & \begin{tabular}{|l} 
Not in \\
Evidence \\
1
\end{tabular} \\
\hline $\begin{array}{l}\text { Topic } \\
\text { Choice/ } \\
\text { Focus } \\
\text { Does the writer } \\
\text { stay focused } \\
\text { on a worthy } \\
\text { topic? }\end{array}$ & $\begin{array}{l}\text {-Skillfully } \\
\text { develops a } \\
\text { focused } \\
\text { central idea } \\
\\
\end{array}$ & $\begin{array}{l}\text {-Develops a central } \\
\text { idea } \\
\text {-Maintains focus on } \\
\text { most important } \\
\text { facts/ideas }\end{array}$ & $\begin{array}{l}\text {-Central idea is } \\
\text { under- developed/ } \\
\text { overly broad } \\
\text {-Attempts focus }\end{array}$ & $\begin{array}{l}\text {-Central idea is } \\
\text { absent } \\
\text {-Little or no evidence } \\
\text { of focus }\end{array}$ \\
\hline $\begin{array}{l}\text { Process } \\
\text { (prewriting, } \\
\text { research, } \\
\text { drafting, } \\
\text { revising, } \\
\text { editing and } \\
\text { publishing) }\end{array}$ & $\begin{array}{l}\text {-Evidence that } \\
\text { all steps of the } \\
\text { writing process } \\
\text { have } \\
\text { successfully } \\
\text { enhanced the } \\
\text { final product }\end{array}$ & $\begin{array}{l}\text {-Evidence of most } \\
\text { steps of the writing } \\
\text { process }\end{array}$ & $\begin{array}{l}\text {-Evidence of some } \\
\text { steps of the writing } \\
\text { process }\end{array}$ & $\begin{array}{l}\text {-Evidence of only } \\
\text { one step of the } \\
\text { writing process }\end{array}$ \\
\hline Research & $\begin{array}{l}\text {-Facts are } \\
\text { accurate, } \\
\text { relevant and } \\
\text { complete } \\
\text {-Written in own } \\
\text { words }\end{array}$ & $\begin{array}{l}\text {-Facts are accurate } \\
\text { and relevant } \\
\text {-Written in own } \\
\text { words }\end{array}$ & $\begin{array}{l}\text {-Attempts accurate facts } \\
\text {-Demonstrates difficulty } \\
\text { writing in own words }\end{array}$ & -No facts evident \\
\hline $\begin{array}{l}\text { Organ- } \\
\text { ization } \\
\text { Does the } \\
\text { organizational } \\
\text { structure } \\
\text { enhance the } \\
\text { ideas and } \\
\text { make it easier } \\
\text { to understand? }\end{array}$ & $\begin{array}{l}\text {-Information is } \\
\text { organized in a } \\
\text { logical coherent } \\
\text { way } \\
\text {-Approp- } \\
\text { riate text } \\
\text { features } \\
\text { enhance } \\
\text { organization }\end{array}$ & $\begin{array}{l}\text {-Related } \\
\text { information is } \\
\text { grouped } \\
\text { together } \\
\text {-Includes } \\
\text { nonfiction text } \\
\text { features (titles, } \\
\text { labeled } \\
\text { diagrams, } \\
\text { captions...) }\end{array}$ & $\begin{array}{l}\text {-Attempts to group } \\
\text { ideas; may be } \\
\text { inconsistent } \\
\text {-Minimal or no text } \\
\text { features }\end{array}$ & $\begin{array}{l}\text {-Informati } \\
\text { on lacks } \\
\text { organizati } \\
\text { on }\end{array}$ \\
\hline
\end{tabular}




\begin{tabular}{|c|c|c|c|c|}
\hline $\begin{array}{l}\text { Author's } \\
\text { Craft }\end{array}$ & $\begin{array}{l}\text {-Interesting, well- } \\
\text { developed opening } \\
\text {-Facts presented } \\
\text { fluently } \\
\text { without } \\
\text { personal } \\
\text { connections/ } \\
\text { opinions } \\
\text {-Facts are } \\
\text { elaborated } \\
\text { using } \\
\text { examples } \\
\text { and/or } \\
\text { explanations } \\
\text {-A variety of } \\
\text { sentence } \\
\text { structures } \\
\text { enhance } \\
\text { meaning/effect } \\
\text {-Effective closing }\end{array}$ & $\begin{array}{l}\text {-Interesting opening } \\
\text {-Includes facts } \\
\text { without } \\
\text { personal } \\
\text { connections/ } \\
\text { opinions } \\
\text {-Facts are elaborated } \\
\text { using } \\
\text { some examples } \\
\text { and/or } \\
\text { explanations } \\
\text {-Uses complete } \\
\text { sentences } \\
\text {-Effective closing } \\
\end{array}$ & $\begin{array}{l}\text {-Attempts opening } \\
\text {-May include personal } \\
\text { connections/opinions } \\
\text {-Minimal examples } \\
\text { and/or } \\
\text { elaboration (list of } \\
\text { facts) } \\
\text {-Attempts to use } \\
\text { complete sentences } \\
\text {-Attempts closing; } \\
\text { may be ineffective }\end{array}$ & $\begin{array}{l}\text {-Lacks elaboration } \\
\text {-Incomplete } \\
\text { sentences } \\
\text {-Lacks } \\
\text { appropriat } \\
\text { e } \\
\text { opening/ } \\
\text { closing }\end{array}$ \\
\hline $\begin{array}{l}\text { Voice } \\
\text { Is the writer's } \\
\text { tone } \\
\text { engaging? } \\
\text { Does } \\
\text { the writer } \\
\text { sound like } \\
\text { an expert? }\end{array}$ & $\begin{array}{l}\text {-Voice: sounds } \\
\text { like an expert } \\
\text {-Voice is } \\
\text { appropriate, } \\
\text { balanced, \& } \\
\text { successfully } \\
\text { enhances the } \\
\text { writing }\end{array}$ & $\begin{array}{l}\text {-Voice: sounds } \\
\text { like an expert } \\
\text {-Voice adds } \\
\text { interest to the } \\
\text { writing }\end{array}$ & $\begin{array}{l}\text {-Voice: attempts to } \\
\text { sound like an expert; } \\
\text { ineffective } \\
\text {-Voice attempts } \\
\text { to add interest; } \\
\text { ineffective }\end{array}$ & -No voice evident \\
\hline $\begin{array}{l}\text { Word } \\
\text { Choice Do } \\
\text { the words and } \\
\text { phrases create } \\
\text { vivid images } \\
\text { in the reader's } \\
\text { mind? }\end{array}$ & $\begin{array}{l}\text {-Attention to word } \\
\text { choice skillfully } \\
\text { enhances the } \\
\text { writing } \\
\text {-Uses precise } \\
\text { subject- } \\
\text { specific } \\
\text { vocabulary }\end{array}$ & $\begin{array}{l}\text {-Uses detail and } \\
\text { description to } \\
\text { give more } \\
\text { information/creat } \\
\text { e image for } \\
\text { reader } \\
\text {-Uses subject } \\
\text { specific } \\
\text { vocabulary }\end{array}$ & $\begin{array}{l}\text {-Attempts to include } \\
\text { detail and description; } \\
\text { may be ineffective } \\
\text {-Minimal } \\
\text { evidence of } \\
\text { subject specific } \\
\text { vocabulary }\end{array}$ & $\begin{array}{l}\text {-No evidence of } \\
\text { attention to word } \\
\text { choice } \\
\text {-Basic vocabulary }\end{array}$ \\
\hline $\begin{array}{l}\text { Revision } \\
\text { Does the } \\
\text { writer use } \\
\text { revision } \\
\text { strategies to } \\
\text { improve the } \\
\text { writing? }\end{array}$ & $\begin{array}{l}\text {-Revisions } \\
\text { have } \\
\text { successfully } \\
\text { lifted the } \\
\text { quality of the } \\
\text { writing } \\
\text { throughout }\end{array}$ & $\begin{array}{l}\text {-Uses revision to } \\
\text { make changes to } \\
\text { the content of the } \\
\text { writing }\end{array}$ & $\begin{array}{l}\text {-Few attempts at } \\
\text { revision; } \\
\text { ineffective }\end{array}$ & $\begin{array}{l}\text {-No evidence of } \\
\text { revision }\end{array}$ \\
\hline \begin{tabular}{|l} 
Conventions \\
\end{tabular} & $\begin{array}{l}\text {-Shows } \\
\text { creativity and } \\
\text { flexibility when } \\
\text { using } \\
\text { conventions to } \\
\text { enhance } \\
\text { meaning } \\
\text {-Evidence of } \\
\text { student } \\
\text { editing }\end{array}$ & $\begin{array}{l}\text {-Uses grade level } \\
\text { conventions; errors } \\
\text { are minor and do } \\
\text { not obscure } \\
\text { meaning } \\
\text {-Evidence of } \\
\text { student } \\
\text { editing }\end{array}$ & $\begin{array}{l}\text {-Uses grade } \\
\text { level } \\
\text { conventions; } \\
\text { errors } \\
\text { occasionally } \\
\text { obscure } \\
\text { meaning } \\
\text {-Minimal evidence of } \\
\text { student editing }\end{array}$ & $\begin{array}{l}\text {-Limited } \\
\text { understanding of } \\
\text { grade level } \\
\text { conventions } \\
\text {-No evidence of } \\
\text { student } \\
\text { Editing }\end{array}$ \\
\hline
\end{tabular}

Total: 136 
Name:

Date:

Class:

FIFTH GRADE Poetry Rubric

\begin{tabular}{|c|c|c|c|c|}
\hline $\begin{array}{l}\text { Content \& } \\
\text { Form }\end{array}$ & $\begin{array}{l}\text { Exceeds } \\
\text { Standards } \\
4\end{array}$ & $\begin{array}{l}\text { Meets } \\
\text { Standards } \\
3\end{array}$ & $\begin{array}{l}\text { Making Progress } \\
\text { toward Standards } \\
2\end{array}$ & $\begin{array}{l}\text { Not in } \\
\text { Evidence } \\
\mathbf{1}\end{array}$ \\
\hline $\begin{array}{l}\text { Topic } \\
\text { Choice/ } \\
\text { Focus }\end{array}$ & $\begin{array}{l}\text { Focuses on a topic } \\
\text { that is built on the } \\
\text { foundation of a } \\
\text { strong image, } \\
\text { emotion, and/or } \\
\text { music. Has a double } \\
\text { focus. }\end{array}$ & $\begin{array}{l}\text { Focuses on a } \\
\text { topic that is } \\
\text { built on the } \\
\text { foundation of a } \\
\text { strong image, } \\
\text { emotion, and/or } \\
\text { music. }\end{array}$ & $\begin{array}{l}\text { Attempts a topic that is } \\
\text { built on the foundation } \\
\text { of a strong image, } \\
\text { emotion, and/or music. } \\
\text { Topic may be } \\
\text { vague or too many } \\
\text { topics compete. }\end{array}$ & $\begin{array}{l}\text { Idea is unclear or } \\
\text { unfocused. May } \\
\text { include random } \\
\text { ideas. }\end{array}$ \\
\hline $\begin{array}{l}\text { Process } \\
\text { (drafting, } \\
\text { revising, } \\
\text { editing and } \\
\text { publishing) }\end{array}$ & $\begin{array}{l}\text { Evidence that all } \\
\text { steps of the writing } \\
\text { process have } \\
\text { successfully } \\
\text { enhanced the final } \\
\text { product. }\end{array}$ & $\begin{array}{l}\text { Evidence of all } \\
\text { steps of the } \\
\text { writing process. }\end{array}$ & $\begin{array}{l}\text { Evidence of some } \\
\text { steps of the writing } \\
\text { process. }\end{array}$ & $\begin{array}{l}\text { Evidence of only } \\
\text { one step of the } \\
\text { writing process. }\end{array}$ \\
\hline $\begin{array}{l}\text { Organization } \\
\text { (Structure) }\end{array}$ & $\begin{array}{l}\text { Uses form, line breaks } \\
\text { and white space to } \\
\text { effectively } \\
\text { create rhythm and } \\
\text { convey meaning. } \\
\text { The poem } \\
\text { communicates a } \\
\text { strong feeling } \\
\text { and/or a vivid } \\
\text { image. }\end{array}$ & $\begin{array}{l}\text { Uses form, line } \\
\text { breaks, and } \\
\text { white space to } \\
\text { effectively } \\
\text { create rhythm } \\
\text { and convey } \\
\text { meaning. }\end{array}$ & $\begin{array}{l}\text { Attempts to use } \\
\text { form, line breaks, } \\
\text { and white space to } \\
\text { convey meaning, but } \\
\text { may be ineffective. }\end{array}$ & $\begin{array}{l}\text { Lacks poetic } \\
\text { structure. }\end{array}$ \\
\hline $\begin{array}{l}\text { Author's } \\
\text { Craft }\end{array}$ & $\begin{array}{l}\text { - Poem engages the } \\
\text { reader immediately } \\
\text { and continuously. } \\
\text {-Fragments have } \\
\text { been used } \\
\text { appropriately. } \\
\text {-Poem ends with } \\
\text { the strongest line } \\
\text { and gives a clear } \\
\text { sense of closure. }\end{array}$ & $\begin{array}{l}\text {-Evidence } \\
\text { of an enticing } \\
\text { opening that } \\
\text { catches the } \\
\text { reader's } \\
\text { attention. } \\
\text {-Fragments have } \\
\text { been used } \\
\text { appropriately. } \\
\text {-Poem } \\
\text { ends } \\
\text { with the } \\
\text { strongest } \\
\text { line. }\end{array}$ & $\begin{array}{l}\text {-Attempts an } \\
\text { opening that catches } \\
\text { the reader's attention. } \\
\text { - Attempts to use } \\
\text { fragments, but may } \\
\text { be inappropriate. } \\
\text {-Attempts a basic } \\
\text { ending, but may } \\
\text { be unclear. }\end{array}$ & $\begin{array}{l}\text { Lacks } \\
\text { appropriate } \\
\text { opening and/or } \\
\text { closing. }\end{array}$ \\
\hline Voice & $\begin{array}{l}\text { Voice } \\
\text { successfully } \\
\text { enhances the } \\
\text { writing. } \\
\text { It is appropriate, } \\
\text { balanced, } \\
\text { and reflects the } \\
\text { author's personality } \\
\text { and awareness of } \\
\text { audience. }\end{array}$ & $\begin{array}{l}\text { Voice is } \\
\text { appropriate and } \\
\text { reflects author's } \\
\text { personality and } \\
\text { awareness of } \\
\text { audience. }\end{array}$ & 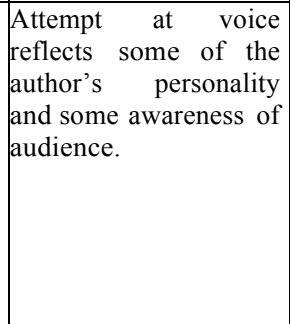 & No voice evident. \\
\hline
\end{tabular}




\begin{tabular}{|c|c|c|c|c|}
\hline $\begin{array}{l}\text { Word } \\
\text { Choice } \\
\text { (precise } \\
\text { words, } \\
\text { descriptive } \\
\text { details, } \\
\text { sensory } \\
\text { language) }\end{array}$ & $\begin{array}{l}\text {-Creates an image } \\
\text { for the reader } \\
\text { using balanced } \\
\text { descriptive } \\
\text { language } \\
\text { throughout the } \\
\text { poem. } \\
\text { - Effectively uses a } \\
\text { balanced variety of } \\
\text { poetic devices and } \\
\text { figurative language } \\
\text { to enhance the } \\
\text { writing } \\
\text { (similes/metaphors, } \\
\text { personification, etc.) }\end{array}$ & \begin{tabular}{|l|}
-Creates an \\
image for the \\
reader using \\
balanced \\
descriptive \\
language \\
throughout the \\
poem. \\
- Includes poetic \\
devices and \\
figurative \\
language \\
(hyphenated \\
adjectives, \\
similes/metaphors, \\
personification, etc.)
\end{tabular} & $\begin{array}{l}\text {-Attempts to } \\
\text { include detail, } \\
\text { sensory description, } \\
\text { and/or poetic } \\
\text { devices/figurative } \\
\text { language, but may } \\
\text { be ineffective. }\end{array}$ & $\begin{array}{l}\text {-Lacks detail } \\
\text { and/or sensory } \\
\text { description. } \\
\text {-Basic word choice }\end{array}$ \\
\hline Revision & $\begin{array}{l}\text { Demonstrates an } \\
\text { understanding of the } \\
\text { purpose of } \\
\text { revision } \\
\text { throughout the } \\
\text { poem; } \\
\text { revisions have } \\
\text { successfully } \\
\text { enhanced the } \\
\text { content, mood and } \\
\text { image. }\end{array}$ & $\begin{array}{l}\text { Demonstrates an } \\
\text { understanding of } \\
\text { the purpose of } \\
\text { revision; writer } \\
\text { has used } \\
\text { at least one } \\
\text { revision } \\
\text { strategy to try } \\
\text { to improve the } \\
\text { content of the } \\
\text { writing. }\end{array}$ & $\begin{array}{l}\text { Few attempts at } \\
\text { revision with minimal } \\
\text { effort to improve the } \\
\text { content. }\end{array}$ & $\begin{array}{l}\text { No evidence of } \\
\text { revision. }\end{array}$ \\
\hline $\begin{array}{l}\text { Spelling } \\
\& \\
\text { Editing }\end{array}$ & \multicolumn{2}{|l|}{$\begin{array}{l}\text { Meets Standards } \\
1 \text { (for each of the } \\
\text { following) }\end{array}$} & \multicolumn{2}{|c|}{$\begin{array}{l}\text { Does Not Meet Standards } \\
0 \text { (for each of the following) }\end{array}$} \\
\hline $\begin{array}{l}\text { Spelling } \\
\text { Strategies }\end{array}$ & \multicolumn{2}{|c|}{$\begin{array}{l}\text { Correct spelling of grade-level } \\
\text { appropriate words. Use of } \\
\text { spelling strategies/resources } \\
\text { is evident. }\end{array}$} & \multicolumn{2}{|c|}{$\begin{array}{l}\text { Incorrect spelling of grade-level } \\
\text { appropriate words. Use of } \\
\text { spelling strategies/resources is } \\
\text { not evident. }\end{array}$} \\
\hline Editing & \multicolumn{2}{|c|}{ Evidence of editing appropriate to form. } & \multicolumn{2}{|c|}{ Little or no evidence of editing. } \\
\hline
\end{tabular}

Total: 130

Comments: 


\begin{tabular}{|c|c|c|c|}
\hline $\begin{array}{l}\text { Student } \\
\text { Name }\end{array}$ & $\begin{array}{l}\text { WHAT needs } \\
\text { improvement }\end{array}$ & $\begin{array}{l}\text { WHY he/ she isn't } \\
\text { getting it }\end{array}$ & HOW to improve \\
\hline Student & \begin{tabular}{|cc} 
Comp (written): \\
- & $\begin{array}{l}\text { Critical thinking } \\
\text { (not going the }\end{array}$ \\
distance) \\
Fluency & \\
- & rate \\
- & punctuation \\
Spelling & expression
\end{tabular} & $\begin{array}{l}\text { His factual comprehension was } \\
\text { there, but he wasn't thinking } \\
\text { about how each piece of the } \\
\text { story goes together with others. } \\
\text { Must practice fluency at } \\
\text { home and school. } \\
\text { Spelling practice at home due } \\
\text { Fridays. }\end{array}$ & $\begin{array}{l}\text { Provide Mac and Mom with Written } \\
\text { Response CFS. } \\
\text { GR Conf: I read you point. } \\
\text { - } \quad \text { Point to the end mark. } \\
\text { - } \quad \text { Any dialogue? } \\
\text { - I read, you swoop. } \\
\text { - You read and swoop. } \\
\text { - } \quad \text { Reread to fluency } \\
\quad \text { ushat's happening? How does that help } \\
\text { us think about the plot?" }\end{array}$ \\
\hline \multicolumn{4}{|l|}{ Notes: } \\
\hline
\end{tabular}

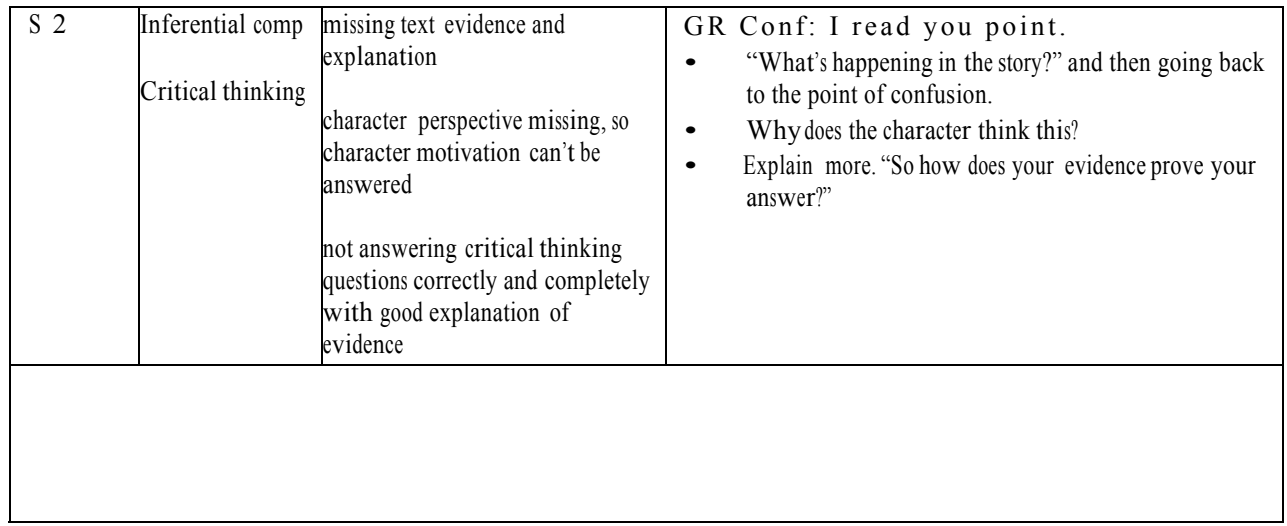

\begin{tabular}{|l|l|l|l|}
\hline S 3 & $\begin{array}{l}\text { Critical } \\
\text { thinking }\end{array}$ & $\begin{array}{l}\text { Did not tell specific } \\
\text { details about } \\
\text { characters (traits) based } \\
\text { upon evidence from text }\end{array}$ & $\begin{array}{l}\text { GR Conf: I read your } \\
\text { point. } \\
-\end{array}$ \\
\hline & $\begin{array}{l}\text { "Does that help me get to know everything I need to know about the } \\
\text { character? How does knowing that help me understand the plot?" }\end{array}$ \\
\hline
\end{tabular}




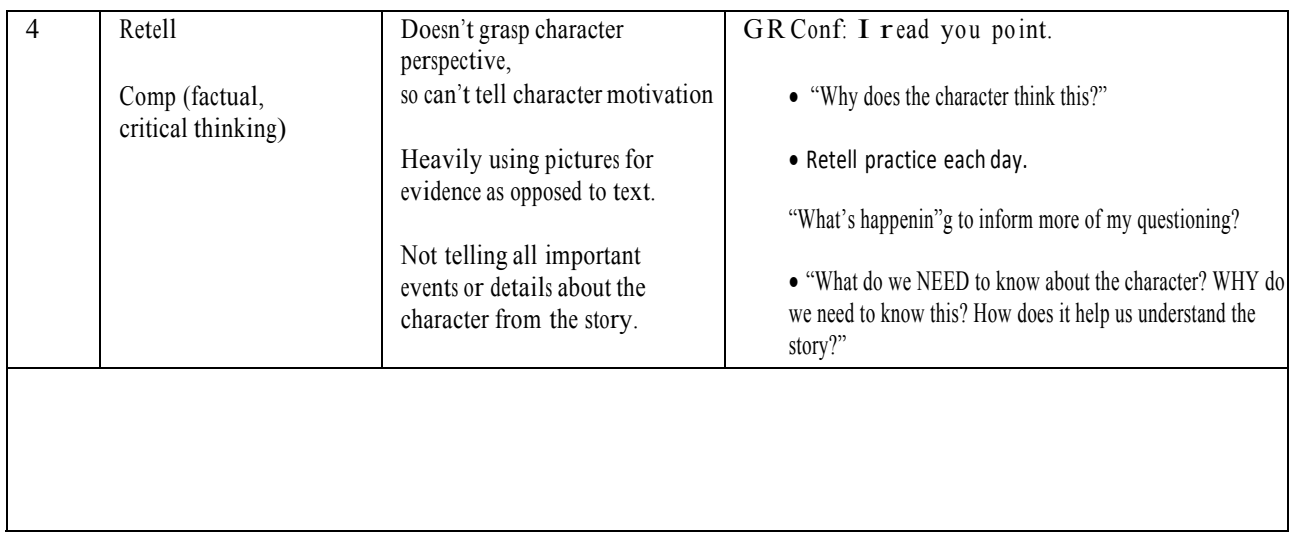

\begin{tabular}{|l|l|l|l|}
\hline 5 & $\begin{array}{l}\text { comparing/ contrasting } \\
\text { characters }\end{array}$ & $\begin{array}{l}\text { didn't look back in the text to where } \\
\text { the } \\
\text { characters were together and } \\
\text { talking didn't see what the } \\
\text { character said } \\
\text { character motivation }\end{array}$ & $\begin{array}{l}\text { W That does the } \\
\text { didn't know what the } \\
\text { character has learned/ what the } \\
\text { character believes }\end{array}$ \\
\hline
\end{tabular}

\begin{tabular}{|l|l|l|l|}
\hline Student 6 & $\begin{array}{l}\text { character } \\
\text { perspective } \\
\text { factual }\end{array}$ & $\begin{array}{l}\text { not telling all details about } \\
\text { character }\end{array}$ & $\begin{array}{l}\text { "What do you know } \\
\text { about_? How does that push help us understand the plot?" } \\
\text { not going back to the text }\end{array}$ \\
\hline
\end{tabular}


[Vol. 41:713

\begin{tabular}{|c|c|c|}
\hline China Relief Map Activity (50 Points) & & China Relief Map Activity (50 Points) \\
\hline Name (1) & & Name (1) \\
\hline Title (1) & & Title (1) \\
\hline Key (1) & _ & Key (1) \\
\hline Compass Rose (1) & _ & Compass Rose (1) \\
\hline Continental View Map (1) & _ & Continental View Map (1) \\
\hline Map Assembly (10) & - & Map Assembly (10) \\
\hline Neatness $(10)$ & - & Neatness (10) \\
\hline 8 Regions (3pts each) & & 8 Regions (3pts each) \\
\hline Total Points Earned & & Total Points Earned \\
\hline China Relief Map Activity (50 Points) & & China Relief Map Activity (50 Points) \\
\hline Name (1) & 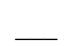 & Name (1) \\
\hline Title (1) & - & Title (1) \\
\hline Key (1) & - & Key (1) \\
\hline Compass Rose (1) & 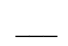 & Compass Rose (1) \\
\hline Continental View Map (1) & 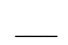 & Continental View Map (1) \\
\hline Map Assembly (10) & - & Map Assembly (10) \\
\hline Neatness (10) & - & Neatness (10) \\
\hline 8 Regions (3pts each) & - & 8 Regions (3pts each) \\
\hline Total Points Earned & - & Total Points Earned \\
\hline
\end{tabular}




\section{Journey to Jo'Burg Comic Life Project}

Total Score: _ $/ 60$ points

Theme: $\quad / 10$ points

- Theme is stated in a complete sentence _ $/ 2$

- Theme is correctly identified

Event One: _ _ 15 points

- Event supports the theme

- Quote is used to help support the theme $\quad$ /5

- Pictures/other text are present to support the theme $\quad$ -

Event Two: $\quad$ / 15 points

- Event supports the theme 15

- Quote is used to help support the theme 15

- Pictures/other text are present to support the theme $\quad$ /5

Event Three: _ _ 15 points

- Event supports the theme

- Quote is used to help support the theme 15

- Pictures/other text are present to support the theme 15

Restatement: _ $\quad 15$ points

- Theme is restated in a new way 18 
Name: Date: Class:

\begin{tabular}{|c|c|c|c|c|}
\hline $\begin{array}{l}\text { Content \& } \\
\text { Form }\end{array}$ & \begin{tabular}{|l} 
Exceeds \\
Standards \\
4
\end{tabular} & \begin{tabular}{|l|} 
Meets \\
Standards \\
3
\end{tabular} & \begin{tabular}{|l} 
Making Progress \\
toward Standards \\
2
\end{tabular} & \begin{tabular}{|l} 
Not in \\
Evidence \\
1
\end{tabular} \\
\hline $\begin{array}{l}\text { Topic Choice/ } \\
\text { Focus }\end{array}$ & $\begin{array}{l}\text {-Sustains focus on } \\
\text { narrative topic with a } \\
\text { well-elaborated event } \\
\text { or sequence of events }\end{array}$ & $\begin{array}{l}\text {-Develops a } \\
\text { focused narrative } \\
\text { with an } \\
\text { elaborated event } \\
\text { or short sequence } \\
\text { of events }\end{array}$ & $\begin{array}{l}\text {-Attempts to develop a } \\
\text { narrative with an } \\
\text { elaborated event or short } \\
\text { sequence of events but } \\
\text { lacks focus }\end{array}$ & $\begin{array}{l}\text {-Topic is } \\
\text { unsuitable for } \\
\text { narrative }\end{array}$ \\
\hline \begin{tabular}{|l} 
Process \\
(prewriting, \\
drafting, \\
revising, \\
editing and \\
publishing)
\end{tabular} & $\begin{array}{l}\text {-Evidence that all } \\
\text { steps of the writing } \\
\text { process have } \\
\text { successfully } \\
\text { enhanced the final } \\
\text { product }\end{array}$ & $\begin{array}{l}\text {-Evidence of most } \\
\text { steps of the writing } \\
\text { process. }\end{array}$ & $\begin{array}{l}\text {-Evidence of some } \\
\text { steps of the writing } \\
\text { process. }\end{array}$ & $\begin{array}{l}\text {-Evidence of only one } \\
\text { step } \\
\text { of the writing process }\end{array}$ \\
\hline $\begin{array}{l}\text { Organization } \\
\text { (story structure) }\end{array}$ & $\begin{array}{l}\text {-Story unfolds } \\
\text { naturally with an } \\
\text { appropriate structure } \\
\text { that enhances the } \\
\text { writing } \\
\text {-Uses a variety of } \\
\text { transition words to } \\
\text { signal order of events }\end{array}$ & \begin{tabular}{|l|}
-Story unfolds \\
naturally with a \\
beginning- \\
middle- end \\
structure \\
-Uses transition \\
words to signal orde \\
of events
\end{tabular} & $\begin{array}{l}\text {-Attempts a story } \\
\text { structure; } \\
\text { may be lacking/confusing } \\
\text {-Uses some transition } \\
\text { words, may be repetitive } \\
\text { or ineffective }\end{array}$ & $\begin{array}{l}\text {-Lacks story structure } \\
\text {-Lacks transition } \\
\text { owords }\end{array}$ \\
\hline $\begin{array}{l}\text { Author's } \\
\text { Craft: } \\
\text { Opening/ } \\
\text { Ending }\end{array}$ & $\begin{array}{l}\text {-Enticing, } \\
\text { well- } \\
\text { developed } \\
\text { opening } \\
\text { draws the } \\
\text { reader in } \\
\text {-Uses advanced } \\
\text { strategy to create } \\
\text { effective ending } \\
\text { that enhances the } \\
\text { writing } \\
\end{array}$ & \begin{tabular}{|l|}
-Enticing \\
opening draws \\
the reader in \\
-Effective ending \\
provides a sense of \\
closure
\end{tabular} & $\begin{array}{l}\text {-Attempts a basic } \\
\text { opening; ineffective } \\
\text {-Attempts a basic ending; } \\
\text { may be illogical or abrupt }\end{array}$ & $\begin{array}{l}\text {-Lacks an } \\
\text { appropriate } \\
\text { opening/ } \\
\text { Closing }\end{array}$ \\
\hline \begin{tabular}{|l|} 
Author's \\
Craft: \\
General \\
Techniques
\end{tabular} & $\begin{array}{l}\text { - A balanced variety } \\
\text { of actions, thoughts } \\
\text { and feelings are } \\
\text { included throughout }\end{array}$ & $\begin{array}{l}\text {-Actions, } \\
\text { thoughts and } \\
\text { feelings are } \\
\text { included } \\
\text { throughout }\end{array}$ & $\begin{array}{l}\text {-Attempts to } \\
\text { include actions, } \\
\text { thoughts and } \\
\text { feelings; } \\
\text { inconsistent }\end{array}$ & $\begin{array}{l}\text {-Lacks actions, } \\
\text { thoughts and } \\
\text { feelings }\end{array}$ \\
\hline $\begin{array}{l}\text { Voice } \\
\text { Is the writer's } \\
\text { tone engaging? }\end{array}$ & $\begin{array}{l}\text {-Voice } \\
\text { successfully } \\
\text { enhances the } \\
\text { writing } \\
\text {-Voice is } \\
\text { appropriate, } \\
\text { balanced, and } \\
\text { reflects author's } \\
\text { personality and } \\
\text { awareness of } \\
\text { audience }\end{array}$ & $\begin{array}{l}\text {-Voice is } \\
\text { appropriate and } \\
\text { reflects author's } \\
\text { personality and } \\
\text { awareness of } \\
\text { audience }\end{array}$ & $\begin{array}{l}\text {-Attempt at voice } \\
\text { reflects some of the } \\
\text { author's personality } \\
\text { and some awareness } \\
\text { of audience }\end{array}$ & -No voice evident \\
\hline
\end{tabular}




\begin{tabular}{|l|l|l|l|l|}
\hline $\begin{array}{l}\text { Word Choice } \\
\text { (descriptive } \\
\text { words; } \\
\text { thoughts } \\
\text { \& feelings) }\end{array}$ & $\begin{array}{l}\text {-Creates an image for } \\
\text { the reader using } \\
\text { complex detail and } \\
\text { sensory description } \\
\text { appropriate to } \\
\text { purpose/genre }\end{array}$ & $\begin{array}{l}\text {-Creates an image } \\
\text { for the reader } \\
\text { using detail and } \\
\text { sensory } \\
\text { description } \\
\text { appropriate to } \\
\text { purpose/genre }\end{array}$ & $\begin{array}{l}\text {-Descriptions } \\
\text { may be vague, } \\
\text { limited and/or } \\
\text { inappropriate to } \\
\text { purpose/genre }\end{array}$ & $\begin{array}{l}\text {-Lacks detail } \\
\text { and/or } \\
\text { description } \\
\text {-Basic word choice }\end{array}$ \\
\hline Revision & $\begin{array}{l}\text {-Revisions have } \\
\text { successfully lifted } \\
\text { the quality of the } \\
\text { writing throughout }\end{array}$ & $\begin{array}{l}\text {-Uses revision to } \\
\text { make changes to } \\
\text { the content of the } \\
\text { writing }\end{array}$ & $\begin{array}{l}\text {-Few attempts at } \\
\text { revision; }\end{array}$ & $\begin{array}{l}\text {-No evidence of } \\
\text { revision }\end{array}$ \\
\hline Conventions & $\begin{array}{l}\text { Shows creativity and } \\
\text { flexibility when using } \\
\text { conventions to } \\
\text { enhance meaning } \\
\text {-Evidence of } \\
\text { student editing }\end{array}$ & $\begin{array}{l}\text { Uses grade level } \\
\text { conventions; errors } \\
\text { are minor and do } \\
\text { not obscure } \\
\text { meaning } \\
\text {-Evidence of } \\
\text { student } \\
\text { editing }\end{array}$ & $\begin{array}{l}\text {-Uses grade level } \\
\text { conventions; } \\
\text { errors } \\
\text { occasionally } \\
\text { obscure } \\
\text { meaning } \\
\text {-Minimal evidence of } \\
\text { student editing }\end{array}$ & $\begin{array}{l}\text {-Limited } \\
\text { understanding of } \\
\text { grade level } \\
\text { conventions } \\
\text {-No evidence of } \\
\text { student editing }\end{array}$ \\
\hline
\end{tabular}

Total:__/36

Comments: 
Name:

Date:

Class:

THIRD, FOURTH, \& FIFTH GRADE Narrative Writing -

Revised May 2012

\begin{tabular}{|c|c|c|c|c|}
\hline $\begin{array}{l}\text { Content \& } \\
\text { Form }\end{array}$ & $\begin{array}{l}\text { Exceeds } \\
\text { Standards } \\
4\end{array}$ & $\begin{array}{l}\text { Meets } \\
\text { Standards } \\
3\end{array}$ & $\begin{array}{l}\text { Making Progress } \\
\text { toward Standards } \\
2\end{array}$ & $\begin{array}{c}\text { Not in Evidence } \\
1\end{array}$ \\
\hline $\begin{array}{l}\text { Topic Choice/ } \\
\text { Focus }\end{array}$ & $\begin{array}{l}\text {-Skillfully develops } \\
\text { a plot } \\
\text {-Sustains focus, } \\
\text { purpose, \& point of } \\
\text { view }\end{array}$ & $\begin{array}{l}\text {-Develops a plot } \\
\text {-Develops focus, } \\
\text { purpose, and point of } \\
\text { view }\end{array}$ & $\begin{array}{l}\text {-Plot is under- } \\
\text { developed } \\
\text {-Attempts focus, } \\
\text { purpose and point of } \\
\text { view }\end{array}$ & $\begin{array}{l}\text {-Lack of plot; not a } \\
\text { story } \\
\text {-Little or no evidence } \\
\text { of focus, purpose, or } \\
\text { point of view }\end{array}$ \\
\hline $\begin{array}{l}\text { Process } \\
\text { (prewriting, } \\
\text { drafting, } \\
\text { revising, editing } \\
\text { and publishing) }\end{array}$ & $\begin{array}{l}\text {-Evidence that all } \\
\text { steps of the writing } \\
\text { process have } \\
\text { successfully } \\
\text { enhanced final } \\
\text { product }\end{array}$ & $\begin{array}{l}\text {-Evidence of all } \\
\text { steps of the writing } \\
\text { process }\end{array}$ & $\begin{array}{l}\text {-Evidence of some } \\
\text { steps of the writing } \\
\text { process }\end{array}$ & $\begin{array}{l}\text {-Evidence of only one } \\
\text { step of the writing } \\
\text { process }\end{array}$ \\
\hline $\begin{array}{l}\text { Organization } \\
\text { Does the } \\
\text { organizational } \\
\text { structure } \\
\text { support the plot? }\end{array}$ & $\begin{array}{l}\text {-Complex } \\
\text { sequence of } \\
\text { events unfolds } \\
\text { naturally and } \\
\text { logically } \\
\text {-Story structure } \\
\text { enhances the } \\
\text { writing } \\
\text {-Uses a } \\
\text { variety } \\
\text { of Tran- } \\
\text { sitions to } \\
\text { manage } \\
\text { the } \\
\text { Sequence } \\
\text { of events }\end{array}$ & $\begin{array}{l}\text {-Sequence of } \\
\text { events unfolds } \\
\text { naturally and } \\
\text { logically } \\
\text {-Uses appropriate } \\
\text { story structure } \\
\text {-Uses appropriate } \\
\text { transitions to manage } \\
\text { the sequence of events }\end{array}$ & $\begin{array}{l}\text {-Sequence of events is } \\
\text { not always logical } \\
\text { and/or natural } \\
\text {-Attempts story } \\
\text { structure; } \\
\text { may be basic and/or } \\
\text { ineffective } \\
\text {-Attempts transitions; } \\
\text { may be basic, repetitive } \\
\text { and/or ineffective }\end{array}$ & $\begin{array}{l}\text {-Sequence of } \\
\text { events is unclear } \\
\text { and/or } \\
\text { disconnected } \\
\text {-Lacks story structure } \\
\text {-Lacks transitions }\end{array}$ \\
\hline $\begin{array}{l}\text { Author's } \\
\text { Craft: } \\
\text { Opening/ } \\
\text { Ending }\end{array}$ & $\begin{array}{l}\text {-Enticing opening } \\
\text { establishes a } \\
\text { situation and } \\
\text { introduces a } \\
\text { narrator } \\
\text { and/or } \\
\text { characters } \\
\text { with } \\
\text { information } \\
\text { that enhances } \\
\text { plot } \\
\text { development } \\
\text {-Uses advanced } \\
\text { strategy } \\
\text { to create effective } \\
\text { ending that enhances } \\
\text { the writing }\end{array}$ & $\begin{array}{l}\text {-Enticing opening } \\
\text { establishes a situation } \\
\text { and introduces a } \\
\text { narrator and/or } \\
\text { characters } \\
\text {-Effective } \\
\text { ending } \\
\text { provides a } \\
\text { sense of } \\
\text { closure } \\
\end{array}$ & $\begin{array}{l}\text {-Basic opening to } \\
\text { establish a situation and } \\
\text { introduce a narrator } \\
\text { and/or characters; } \\
\text { ineffective } \\
\text {-Basic ending; may be } \\
\text { illogical or abrupt }\end{array}$ & $\begin{array}{l}\text {-Lacks } \\
\text { appropriate } \\
\text { opening/ } \\
\text { ending }\end{array}$ \\
\hline
\end{tabular}




\begin{tabular}{|c|c|c|c|c|}
\hline $\begin{array}{l}\text { Author's } \\
\text { Craft: } \\
\text { General } \\
\text { Techniques }\end{array}$ & $\begin{array}{l}\text {-Uses a balanced } \\
\text { variety of } \\
\text { techniques to } \\
\text { enhance } \\
\text { development of } \\
\text { events and } \\
\text { characters } \\
\text {-Effectively } \\
\text { balances narration } \\
\text { and dialogue to } \\
\text { move the story } \\
\text { along and develop } \\
\text { characters }\end{array}$ & $\begin{array}{l}\text {-Uses description of } \\
\text { actions, thoughts, } \\
\text { feelings and setting to } \\
\text { develop events and } \\
\text { characters } \\
\text {-Uses dialogue } \\
\text { effectively to move } \\
\text { the story along and } \\
\text { develop characters }\end{array}$ & $\begin{array}{l}\text {-Attempts to use } \\
\text { description of } \\
\text { actions, thoughts, } \\
\text { feelings, and/or } \\
\text { setting to develop } \\
\text { events and } \\
\text { characters; may be } \\
\text { vague/ } \\
\text { unbalanced } \\
\text {-Uses dialogue } \\
\text { ineffectively }\end{array}$ & $\begin{array}{l}\text {-No evidence of } \\
\text { event or character } \\
\text { development }\end{array}$ \\
\hline $\begin{array}{l}\text { Voice } \\
\text { Is the writer's } \\
\text { tone engaging? }\end{array}$ & $\begin{array}{l}\text {-Voice } \\
\text { success- } \\
\text { fully } \\
\text { enhances } \\
\text { the } \\
\text { writing } \\
\text {-Voice is } \\
\text { appropriate, } \\
\text { balanced, and } \\
\text { reflects } \\
\text { author's } \\
\text { personality and } \\
\text { awareness of } \\
\text { audience }\end{array}$ & $\begin{array}{l}\text {-Voice is appropriate } \\
\text { and reflects author's } \\
\text { personality and } \\
\text { awareness of audience }\end{array}$ & $\begin{array}{l}\text {-Attempt at voice } \\
\text { reflects some of the } \\
\text { author's personality } \\
\text { and some awareness } \\
\text { of audience }\end{array}$ & -No voice evident \\
\hline $\begin{array}{l}\text { Word Choice Do } \\
\text { the words and } \\
\text { phrases create } \\
\text { vivid images in the } \\
\text { reader's mind? }\end{array}$ & $\begin{array}{l}\text {-Creates an image } \\
\text { for the reader using } \\
\text { complex detail } \\
\text { and sensory } \\
\text { description } \\
\text { appropriate to } \\
\text { purpose/genre } \\
\text {-Effectively uses a } \\
\text { variety of literary } \\
\text { devices }\end{array}$ & $\begin{array}{l}\text {-Creates an image } \\
\text { for the reader using } \\
\text { detail and sensory } \\
\text { description } \\
\text { appropriate to } \\
\text { purpose/genre } \\
\text {-Uses literary } \\
\text { devices when } \\
\text { appropriate }\end{array}$ & $\begin{array}{l}\text {-Descriptions } \\
\text { may be vague, } \\
\text { limited and/or } \\
\text { inappropriate } \\
\text { to purpose/ } \\
\text { genre } \\
\text {-Attempts to use } \\
\text { literary devices; may be } \\
\text { ineffective }\end{array}$ & $\begin{array}{l}\text {-No evidence of detail } \\
\text { and/or sensory } \\
\text { description } \\
\text {-Basic word choice }\end{array}$ \\
\hline $\begin{array}{l}\text { Revision } \\
\text { Does the writer } \\
\text { use revision } \\
\text { strategies to } \\
\text { improve the } \\
\text { writing? }\end{array}$ & $\begin{array}{l}\text {-Revisions } \\
\text { have } \\
\text { successfully } \\
\text { lifted the } \\
\text { quality of the } \\
\text { writing } \\
\text { throughout }\end{array}$ & $\begin{array}{l}\text {-Uses revision to } \\
\text { improve the content } \\
\text { of the writing }\end{array}$ & $\begin{array}{l}\text { - Uses revision; ma } \\
\text { y be superficial } \\
\text { (e.g., at word level) } \\
\text { and/or ineffective }\end{array}$ & $\begin{array}{l}\text {-No evidence of } \\
\text { revision }\end{array}$ \\
\hline Conventions & $\begin{array}{l}\text {-Shows } \\
\text { creativity and } \\
\text { flexibility when } \\
\text { using } \\
\text { conventions to } \\
\text { enhance } \\
\text { meaning } \\
\text {-Evidence of student } \\
\text { editing }\end{array}$ & $\begin{array}{l}\text {-Uses grade level } \\
\text { conventions; } \\
\text { errors are minor } \\
\text { and do not } \\
\text { obscure meaning } \\
\text {-Evidence of student } \\
\text { editing }\end{array}$ & $\begin{array}{l}\text {-Uses grade } \\
\text { level } \\
\text { conventions; } \\
\text { errors } \\
\text { occasionally } \\
\text { obscure } \\
\text { meaning } \\
\text {-Minimal evidence of } \\
\text { student editing }\end{array}$ & $\begin{array}{l}\text {-Limited } \\
\text { understanding of } \\
\text { grade level } \\
\text { conventions } \\
\text {-No evidence of } \\
\text { student editing }\end{array}$ \\
\hline
\end{tabular}


Name:

Date:

Class:

THIRD, FOURTH, \& FIFTH GRADE Opinion Rubric

\begin{tabular}{|c|c|c|c|c|}
\hline $\begin{array}{l}\text { Content \& } \\
\text { Form }\end{array}$ & $\begin{array}{l}\text { Exceeds } \\
\text { Standards } \\
4\end{array}$ & $\begin{array}{l}\text { Meets } \\
\text { Standards } \\
\quad 3\end{array}$ & $\begin{array}{l}\text { Making Progress } \\
\text { Toward Standards } \\
2\end{array}$ & $\begin{array}{l}\text { Not in } \\
\text { Evidence } \\
\quad 1\end{array}$ \\
\hline $\begin{array}{l}\text { Topic } \\
\text { Choice/Focus }\end{array}$ & $\begin{array}{l}\text {-Independently selects a } \\
\text { meaningful topic } \\
\text {-States a clear, } \\
\text { concise, strong } \\
\text { opinion; maintains } \\
\text { focus with well- } \\
\text { elaborated support }\end{array}$ & $\begin{array}{l}\text { - Independently selects } \\
\text { topic } \\
\text { - Clearly establishes } \\
\text { point of view; maintains } \\
\text { focus on opinion } \\
\text { Throughout }\end{array}$ & $\begin{array}{l}\text {-Selects topic with } \\
\text { support } \\
\text {-Attempts to establish } \\
\text { point of view; lacks focus } \\
\text { (opinion unclear or } \\
\text { inconsistent) }\end{array}$ & $\begin{array}{l}\text {-Topic is } \\
\text { unsuitable } \\
\text { for } \\
\text { opinion }\end{array}$ \\
\hline $\begin{array}{l}\text { Process } \\
\text { (prewriting, } \\
\text { drafting, } \\
\text { revising, } \\
\text { editing and } \\
\text { publishing) }\end{array}$ & $\begin{array}{l}\text {-Evidence that all steps } \\
\text { of the writing process } \\
\text { have successfully } \\
\text { enhanced the final } \\
\text { product }\end{array}$ & $\begin{array}{l}\text {-Evidence of most } \\
\text { steps of the writing } \\
\text { process. }\end{array}$ & $\begin{array}{l}\text {-Evidence of some steps } \\
\text { of the writing process. }\end{array}$ & $\begin{array}{l}\text {-Evidence of } \\
\text { only one step } \\
\text { of the writing } \\
\text { process }\end{array}$ \\
\hline Organization & $\begin{array}{l}\text {-Writer's purpose is } \\
\text { enhanced by clear } \\
\text { organization of reasons } \\
\text { and ideas throughout } \\
\text { multiple paragraphs }\end{array}$ & $\begin{array}{l}\text {-Related ideas are } \\
\text { grouped to support } \\
\text { writer's purpose } \\
\text {-Paragraphs follow logical } \\
\text { Sequence }\end{array}$ & $\begin{array}{l}\text {-Attempts to group ideas; } \\
\text { may not be logical }\end{array}$ & -Lacks structure \\
\hline $\begin{array}{l}\text { Author's } \\
\text { Craft: } \\
\text { Opening/ } \\
\text { Ending }\end{array}$ & $\begin{array}{l}\text {-Enticing, well- } \\
\text { developed opening } \\
\text { is concise, makes a } \\
\text { strong statement \& } \\
\text { draws the reader in } \\
\text {-Provides a strong and } \\
\text { effective concluding } \\
\text { section that relates to } \\
\text { the opinion }\end{array}$ & $\begin{array}{l}\text {-Opening introduces } \\
\text { the topic, states an } \\
\text { opinion \& draws the } \\
\text { reader in } \\
\text {-Ending statement or } \\
\text { section is related to the } \\
\text { opinion; leaves a } \\
\text { strong message }\end{array}$ & $\begin{array}{l}\text {-Attempts a basic } \\
\text { opening; } \\
\text { ineffective } \\
\text {-Attempts an ending; } \\
\text { ineffective }\end{array}$ & $\begin{array}{l}\text {-Lacks an } \\
\text { appropriate } \\
\text { opening/ } \\
\text { closing }\end{array}$ \\
\hline $\begin{array}{l}\text { Author's } \\
\text { Craft: } \\
\text { General } \\
\text { Techniques }\end{array}$ & $\begin{array}{l}\text {-Details and examples } \\
\text { thoroughly elaborate } \\
\text { multiple reasons } \\
\text {-Uses linking words, } \\
\text { phrases and clauses } \\
\text { to connect opinion \& } \\
\text { reasons } \\
\text {-Awareness of audience } \\
\text { enhances } \\
\text { Writing }\end{array}$ & $\begin{array}{l}\text {-Details and relevant } \\
\text { information } \\
\text { support point of view } \\
\text {-Uses linking words (gr 3) } \\
\text { phrases } \\
\text { (gr 4) and/or } \\
\text { clauses (gr 5) to } \\
\text { connect opinion } \\
\text { and reasons } \\
\text {-Demonstrates } \\
\text { awareness of } \\
\text { audience }\end{array}$ & $\begin{array}{l}\text {-Attempts to include details } \\
\text { and relevant information; } \\
\text { do not support point of } \\
\text { view } \\
\text { clauses chosen are } \\
\text { ineffective } \\
\text {-Demonstrates some } \\
\text { awareness of audience }\end{array}$ & $\begin{array}{l}\text {-Lacks reasons } \\
\text {-Lacks word, } \\
\text { phrases, clauses } \\
\text {-Lacks } \\
\text { details and } \\
\text { examples }\end{array}$ \\
\hline $\begin{array}{l}\text { Voice } \\
\text { Is the writer's } \\
\text { tone engaging? }\end{array}$ & $\begin{array}{l}\text {-Voice successfully } \\
\text { enhances } \\
\text { the writing } \\
\text {-Uses multiple } \\
\text { techniques to engage } \\
\text { the audience \& best } \\
\text { communicate the } \\
\text { message }\end{array}$ & $\begin{array}{l}\text {-Voice is appropriate and } \\
\text { reflects style and tone } \\
\text { appropriate for purpose \& } \\
\text { audience }\end{array}$ & $\begin{array}{l}\text {-Attempts to use voice; } \\
\text { ineffective }\end{array}$ & -No voice evident \\
\hline
\end{tabular}




\begin{tabular}{|c|c|c|c|c|}
\hline Word Choice & $\begin{array}{l}\text {-Uses } \\
\text { persuasive/emotive } \\
\text { words effectively } \\
\text { throughout } \\
\text {-Elaborates using } \\
\text { descriptive details } \\
\text { \& domain specific } \\
\text { vocabulary to } \\
\text { convey information, } \\
\text { opinion and reasons } \\
\text { throughout }\end{array}$ & $\begin{array}{l}\text {-Uses persuasive/emotive } \\
\text { words effectively } \\
\text {-Elaborates using } \\
\text { descriptive details \& } \\
\text { domain specific } \\
\text { vocabulary to convey } \\
\text { information, opinion and } \\
\text { reasons }\end{array}$ & $\begin{array}{l}\text {-Attempts to use } \\
\text { persuasive/emotive } \\
\text { words; may be ineffective } \\
\text {-Attempts to elaborate } \\
\text { using descriptive details } \\
\text { \& domain specific details; } \\
\text { may be ineffective }\end{array}$ & $\begin{array}{l}\text {-Basic word } \\
\text { choice }\end{array}$ \\
\hline Revision & $\begin{array}{l}\text {-Revisions have } \\
\text { successfully lifted the } \\
\text { quality of the writing } \\
\text { throughout }\end{array}$ & $\begin{array}{l}\text {-Uses revision to make } \\
\text { changes to the content } \\
\text { of the writing }\end{array}$ & $\begin{array}{l}\text {-Few attempts at } \\
\text { revision; } \\
\text { ineffective }\end{array}$ & $\begin{array}{l}\text {-No evidence } \\
\text { of revision }\end{array}$ \\
\hline Conventions & $\begin{array}{l}\text {-Shows creativity and } \\
\text { flexibility when using } \\
\text { conventions to enhance } \\
\text { meaning } \\
\text {-Evidence of student } \\
\text { editing }\end{array}$ & $\begin{array}{l}\text {-Uses grade level } \\
\text { conventions; errors } \\
\text { are minor and do not } \\
\text { obscure meaning } \\
\text {-Evidence of student } \\
\text { editing }\end{array}$ & $\begin{array}{l}\text {-Uses grade level } \\
\text { conventions; errors } \\
\text { occasionally obscure } \\
\text { meaning } \\
\text {-Minimal evidence of } \\
\text { student editing }\end{array}$ & $\begin{array}{l}\text {-Limited } \\
\text { understanding } \\
\text { of grade level } \\
\text { conventions } \\
\text {-No } \\
\text { evidence of } \\
\text { student } \\
\text { editing }\end{array}$ \\
\hline
\end{tabular}




\begin{tabular}{|c|c|c|c|c|c|}
\hline Criterion & $\begin{array}{l}\text { Above grade } \\
\text { level }\end{array}$ & $\begin{array}{l}\text { Profi- } \\
\text { cient } \\
\text { At grade } \\
\text { level }\end{array}$ & Developing & $\begin{array}{l}\text { Initiat- } \\
\text { ing }\end{array}$ & $\begin{array}{l}\text { Not Yet } \\
\text { Evident }\end{array}$ \\
\hline Focus & $\begin{array}{l}\square \text { Introduces } \\
\text { a topic/text, } \\
\text { states a pre- } \\
\text { cise claim } \\
\text { and main- } \\
\text { tains it } \\
\text { throughout }\end{array}$ & $\begin{array}{l}\text { Introduces a } \\
\text { topic/text, states a rea- } \\
\text { sonable claim and } \\
\text { maintains it through- } \\
\text { out }\end{array}$ & $\begin{array}{l}\text { Introduces a } \\
\text { topic/text, states a } \\
\text { claim and main- } \\
\text { tains it throughout }\end{array}$ & $\begin{array}{l}\square \text { Introduces a } \\
\text { topic/text, states a su- } \\
\text { perficial or flawed } \\
\text { claim }\end{array}$ & $\begin{array}{l}\square \text { Introduces a } \\
\text { topic/text, fails } \\
\text { to state a rele- } \\
\text { vant claim }\end{array}$ \\
\hline $\begin{array}{l}\text { Organiza- } \\
\text { tion }\end{array}$ & $\begin{array}{l}\square \text { Acknowl- } \\
\text { edges and dis- } \\
\text { tinguishes al- } \\
\text { ternate or op- } \\
\text { posing } \\
\text { claim(s) } \\
\square \text { Includes } \\
\text { purposeful } \\
\text { and logical } \\
\text { progression } \\
\text { of ideas from } \\
\text { beginning to } \\
\text { end } \\
\square \text { Creates co- } \\
\text { hesion and } \\
\text { clarifies rela- } \\
\text { tionships } \\
\text { through skillful } \\
\text { use of transi- } \\
\text { tion/linking } \\
\text { words, phrases, } \\
\text { and clauses } \\
\text { within and be- } \\
\text { tween para- } \\
\text { graphs } \\
\square \text { Provides a } \\
\text { meaningful and } \\
\text { reflective con- } \\
\text { clusion which } \\
\text { draws from and } \\
\text { supports } \\
\text { claim(s) } \\
\square \text { Uses ap- } \\
\text { propriate } \\
\text { para- } \\
\text { graphing }\end{array}$ & $\begin{array}{l}\square \text { Acknowledges } \\
\text { and addresses al- } \\
\text { ternate or oppos- } \\
\text { ing claims } \\
\text { Organizes } \\
\text { the reasons } \\
\text { and evidence } \\
\text { logically } \\
\text { Creates cohesion } \\
\text { and clarifies relation- } \\
\text { ships through transi- } \\
\text { tion/linking words, } \\
\text { phrases, and clauses } \\
\text { within and between } \\
\text { paragraphs } \\
\square \text { Provides a } \\
\text { conclusion that } \\
\text { follows from } \\
\text { and supports } \\
\text { claim(s) } \\
\text { Uses appropriate } \\
\text { paragraphing }\end{array}$ & $\begin{array}{l}\square \text { Generally } \\
\text { acknowledges } \\
\text { and addresses } \\
\text { alternate or op- } \\
\text { posing claims } \\
\square \text { Organizes the } \\
\text { reasons and evi- } \\
\text { dence in a gener- } \\
\text { ally logical man- } \\
\text { ner } \\
\square \text { Clarifies rela- } \\
\text { tionships } \\
\text { through basic } \\
\text { transition/linking } \\
\text { words, phrases, } \\
\text { and/or clauses } \\
\text { within or between } \\
\text { paragraphs } \\
\square \text { Provides a } \\
\text { conclusion } \\
\text { which repeti- } \\
\text { tively or par- } \\
\text { tially supports } \\
\text { claim(s) }\end{array}$ & $\begin{array}{l}\square \text { Partially acknowl- } \\
\text { edges and addresses } \\
\text { alternate or oppos- } \\
\text { ing claims } \\
\square \text { Organizes the rea- } \\
\text { sons and evidence } \\
\text { somewhat logically } \\
\square \text { Uses limited } \\
\text { and/or inappro- } \\
\text { priate transi- } \\
\text { tion/linking } \\
\text { words, phrases, } \\
\text { or clauses } \\
\square \text { Provides an } \\
\text { inadequate } \\
\text { conclusion }\end{array}$ & $\begin{array}{l}\square \text { Vaguely } \\
\text { acknowl- } \\
\text { edges and } \\
\text { addresses } \\
\text { alternate or } \\
\text { opposing } \\
\text { claims } \square \text { Il- } \\
\text { logically or- } \\
\text { ganizes the } \\
\text { reasons and } \\
\text { evidence } \\
\text { Uses } \\
\text { few to no } \\
\text { transition/ } \\
\text { linking } \\
\text { words, } \\
\text { phrases, } \\
\text { or clauses } \\
\square \text { Omits conclu- } \\
\text { sion }\end{array}$ \\
\hline
\end{tabular}




\begin{tabular}{|c|c|c|c|c|c|}
\hline Support & $\begin{array}{l}\square \text { Provides sub- } \\
\text { stantial and per- } \\
\text { tinent evidence } \\
\text { to support } \\
\text { claim(s) } \\
\square \text { Effec- } \\
\text { tively inte- } \\
\text { grates and } \\
\text { cites credi- } \\
\text { ble sources } \\
\text { and/or text } \\
\text { evidence } \\
\square \text { Con- } \\
\text { vincingly } \\
\text { refutes } \\
\text { specific } \\
\text { counter- } \\
\text { claim(s) } \\
\square \text { Shows insight- } \\
\text { ful understand- } \\
\text { ing of topic or } \\
\text { text } \\
\square \text { Integrates } \\
\text { multimedia } \\
\text { and visual dis- } \\
\text { plays to } \\
\text { strengthen } \\
\text { claims }\end{array}$ & $\begin{array}{l}\text { Provides suffi- } \\
\text { cient and relevant } \\
\text { evidence to sup- } \\
\text { port claim(s) and } \\
\text { reasoning /with } \\
\text { explanation } \\
\text { Competently } \\
\text { integrates and } \\
\text { cites credible } \\
\text { sources and/or } \\
\text { text evidence } \\
\text { Shows compe- } \\
\text { tent understanding } \\
\text { of topic or text } \\
\square \text { Uses multime- } \\
\text { dia and visual } \\
\text { displays to clar- } \\
\text { ify claims }\end{array}$ & $\begin{array}{l}\square \text { Provides } \\
\text { basic evi- } \\
\text { dence to } \\
\text { support } \\
\text { claim(s) } \\
\square \text { Ineffectively } \\
\text { integrates or } \\
\text { cites adequate } \\
\text { sources and/or } \\
\text { text evidence } \\
\square \text { Shows super- } \\
\text { ficial under- } \\
\text { standing of topic } \\
\text { or text } \\
\square \text { Limited use } \\
\text { of multimedia } \\
\text { and visual dis- } \\
\text { plays to clarify } \\
\text { claims }\end{array}$ & $\begin{array}{l}\square \text { Provides min- } \\
\text { imal and/or ir- } \\
\text { relevant evi- } \\
\text { dence to support } \\
\text { claim(s) } \\
\square \text { Incorrectly inte- } \\
\text { grates or cites sources } \\
\text { and/or text evidence } \\
\text { that may not be credi- } \\
\text { ble } \\
\square \text { Shows limited } \\
\text { and/or flawed under- } \\
\text { standing of topic or } \\
\text { text } \\
\square \text { Ineffective use of } \\
\text { multimedia and visual } \\
\text { displays to clarify } \\
\text { claims }\end{array}$ & $\begin{array}{l}\square \text { Provides } \\
\text { inaccurate, } \\
\text { little, or no } \\
\text { evidence to } \\
\text { support } \\
\text { claim(s) } \\
\square \text { Does not } \\
\text { use or cite } \\
\text { sources } \\
\text { and/or text } \\
\text { evidence } \\
\text { Shows no } \\
\text { and/or inaccu- } \\
\text { rate under- } \\
\text { standing of } \\
\text { topic or text } \\
\square \text { Does not } \\
\text { use multime- } \\
\text { dia and visual } \\
\text { displays }\end{array}$ \\
\hline Style & $\begin{array}{l}\square \text { Strategically } \\
\text { uses convinc- } \\
\text { ing word choice } \\
\text { and domain- } \\
\text { specific vocab- } \\
\text { ulary } \\
\square \text { Uses various } \\
\text { phrases and } \\
\text { clauses to add } \\
\text { variety and in- } \\
\text { terest } \\
\square \text { Establishes } \\
\text { and maintains } \\
\text { formal style } \\
\text { and objective } \\
\text { tone } \\
\square \text { Eliminates } \\
\text { wordiness and } \\
\text { redundancy }\end{array}$ & $\begin{array}{l}\square \text { Uses convincing } \\
\text { word choice and } \\
\text { domain-specific } \\
\text { vocabulary } \\
\text { Uses a vari- } \\
\text { ety of sen- } \\
\text { tence length } \\
\text { and structure } \\
\square \text { Establishes } \\
\text { and maintains a } \\
\text { formal style } \\
\square \text { Eliminates } \\
\text { wordiness } \\
\text { and redun- } \\
\text { dancy }\end{array}$ & $\begin{array}{l}\square \text { Sometimes } \\
\text { uses convinc- } \\
\text { ing word } \\
\text { choice and } \\
\text { domain- spe- } \\
\text { cific vocabu- } \\
\text { lary } \\
\square \text { Minimally } \\
\text { varies sen- } \\
\text { tence length } \\
\text { and struc- } \\
\text { ture } \\
\square \text { At times } \\
\text { uses informal } \\
\text { style } \\
\text { (collo- } \\
\text { quial } \\
\text { words, } \\
\text { etc.) } \\
\square \text { Generally } \\
\text { eliminates } \\
\text { wordiness } \\
\text { and redun- } \\
\text { dancy }\end{array}$ & $\begin{array}{l}\square \text { Inadequately uses } \\
\text { convincing word } \\
\text { choice and domain- } \\
\text { specific vocabulary } \\
\text { Uses limited and/or } \\
\text { repetitive sentence } \\
\text { structure } \\
\text { Combines } \\
\text { formal and } \\
\text { informal } \\
\text { styles } \\
\text { Uses repetitive word } \\
\text { choices }\end{array}$ & $\begin{array}{l}\square \text { Fails to use } \\
\text { convincing } \\
\text { word choice } \\
\text { and domain- } \\
\text { specific vo- } \\
\text { cabulary } \\
\square \text { Lacks sen- } \\
\text { tence mastery } \\
\text { (e.g., frag- } \\
\text { ments/ run- } \\
\text { ons) } \\
\square \text { Does not use } \\
\text { formal style } \\
\square \text { Is re- } \\
\text { petitive } \\
\text { and } \\
\text { without } \\
\text { purpose }\end{array}$ \\
\hline
\end{tabular}


[Vol. 41:713

\begin{tabular}{|c|c|c|c|c|c|}
\hline \begin{tabular}{|l} 
Gram- \\
mar/ \\
Conven- \\
tions
\end{tabular} & $\begin{array}{l}\square \text { Contains } \\
\text { minimal to no } \\
\text { errors in con- } \\
\text { ventions }\end{array}$ & $\begin{array}{l}\square \text { Uses pro- } \\
\text { noun number } \\
\text { and person } \\
\text { accurately } \\
\text { Contains few, } \\
\text { minor errors in } \\
\text { conventions }\end{array}$ & $\begin{array}{l}\square \text { Uses some in- } \\
\text { appropriate shifts } \\
\text { in pronoun num- } \\
\text { ber and person } \\
\text { Contains some } \\
\text { errors in conven- } \\
\text { tions which may } \\
\text { cause confusion }\end{array}$ & $\begin{array}{l}\square \text { Uses inappropriate } \\
\text { shifts in pronoun } \\
\text { number and person } \\
\text { Contains numerous } \\
\text { errors in conventions } \\
\text { which cause confu- } \\
\text { sion }\end{array}$ & $\begin{array}{l}\square \text { Does not } \\
\text { recognize } \\
\text { pronoun } \\
\text { number and } \\
\text { person } \\
\square \text { Contains per- } \\
\text { vasive errors in } \\
\text { conventions that } \\
\text { interfere with } \\
\text { meaning }\end{array}$ \\
\hline
\end{tabular}




\begin{tabular}{|l|l|}
\hline \multicolumn{1}{|c|}{ Trends } & \multicolumn{1}{c|}{ How to Address } \\
\hline Conclusions missing (time) & $\begin{array}{l}\text { More practice will lead to structural fluency and } \\
\text { more time to write }\end{array}$ \\
\hline Explanation in body paragraphs & $\begin{array}{l}\text { Push kids to taking it further by teaching kids } \\
\text { to include appropriate feedback }\end{array}$ \\
\hline $\begin{array}{l}\text { Topic sentences must express the full idea } \\
\text { (topic statements, too) }\end{array}$ & $\begin{array}{l}\text { Inquiry-based INM with kids looking at weak } \\
\text { and strong topic sentences }\end{array}$ \\
& $\begin{array}{l}\text { During the planning and writing of topic } \\
\text { statements, spend more time ensuring all kids } \\
\text { know to include each part of the prompt }\end{array}$ \\
\hline
\end{tabular}

\begin{tabular}{|l|l|}
\hline \multicolumn{1}{|c|}{ Individual Statements } & Bright Spot \\
\cline { 1 - 1 } Hawaii - student names & \multirow{2}{*}{ Strong understanding of structure and ideas } \\
\cline { 1 - 1 } Columbia - student names & \\
\cline { 1 - 1 } ND - student names & \\
\cline { 1 - 2 } Colby - student names & \\
\hline
\end{tabular}

\begin{tabular}{|l|l|}
\hline \multicolumn{1}{|c|}{ Individual Statements } & \multicolumn{1}{c|}{ How to Address } \\
\hline Hawaii - student names & $\begin{array}{l}\text { Prewriting time - small group for ideas and } \\
\text { organization }\end{array}$ \\
\hline Columbia - names & $\begin{array}{l}\text { Small group for ideas and organization } \\
\text { Gabriel - paragraph structure }\end{array}$ \\
\hline ND - student names & Small group for ideas and organization \\
\hline
\end{tabular}




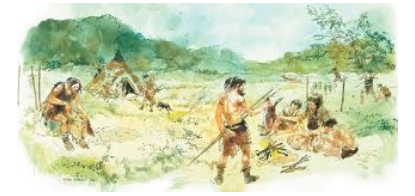

\section{Hunter-Gatherer Groups to Agricultural Societies:}

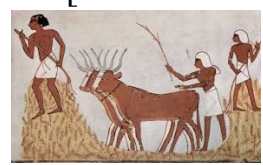

Goal for project:

I can: ...describe the transition of early people from hunter-gatherer societies to agricultural societies.

Task:

Create your own representation of the transition from a hunter-gatherer society. This should include problems with remaining a hunter-gatherer society and the benefits of becoming an agricultural society.

\begin{tabular}{|c|c|c|c|c|}
\hline & $\begin{array}{l}4-\text { EXCEEDS } \\
\text { EXPECTATIONS }\end{array}$ & $\begin{array}{l}3 \text {-MEETS } \\
\text { EXPECTATIONS }\end{array}$ & $\begin{array}{l}\text { 2-APPROACHING } \\
\text { EXPECTATIONS }\end{array}$ & $\begin{array}{l}1-\text { BELOW } \\
\text { EXPECTATIONS }\end{array}$ \\
\hline $\begin{array}{l}\text { IDEAS-DIS- } \\
\text { ADVANTAGES } \\
\text { OF REMAINING } \\
\text { A HUNTER- } \\
\text { GATHERER } \\
\text { GROUP }\end{array}$ & $\begin{array}{l}\text { Student does all things } \\
\text { previously mentioned } \\
\text { and goes above and } \\
\text { beyond in his orher } \\
\text { description of the } \\
\text { problem with a life as a }\end{array}$ & $\begin{array}{l}\text { Student presents multiple } \\
\text { disadvantages of } \\
\text { remaining ahunter- } \\
\text { gatherergroup. }\end{array}$ & $\begin{array}{l}\text { Student presents only 1-2 } \\
\text { disadvantages of } \\
\text { remaining a hunter-gatherer } \\
\text { group. }\end{array}$ & $\begin{array}{l}\text { Student does not present } \\
\text { any disadvantages to } \\
\text { remaining a hunter- } \\
\text { gatherergroup. }\end{array}$ \\
\hline \begin{tabular}{|l|} 
IDEAS- \\
BENEFITS OF" \\
BECOMING AN \\
AGRI- \\
CULTURAL \\
SOCIETY \\
\end{tabular} & $\begin{array}{l}\text { Student does all things } \\
\text { previously mentioned } \\
\text { and goes above and } \\
\text { beyond in his or her } \\
\text { description of the } \\
\text { advantages to a life as an }\end{array}$ & $\begin{array}{l}\text { Student presents multiple } \\
\text { benefits to becoming an } \\
\text { agricultural society. }\end{array}$ & $\begin{array}{l}\text { Student presents only 1-2 } \\
\text { benefits to becoming an } \\
\text { agricultural society. }\end{array}$ & $\begin{array}{l}\text { Student does not present } \\
\text { any disadvantages to } \\
\text { becoming an agricultural } \\
\text { society. }\end{array}$ \\
\hline \begin{tabular}{|l} 
PRESENTATION \\
-COMPLETION \\
OF REQUIRED \\
ELEMENTS \\
\end{tabular} & $\begin{array}{l}\text { Allthings previously } \\
\text { mentioned are done and } \\
\text { in addition there are } \\
\text { multiple details to make } \\
\text { this project personalized. }\end{array}$ & $\begin{array}{l}\text { Allrequired elements for } \\
\text { the individual project } \\
\text { choice are present. }\end{array}$ & $\begin{array}{l}\text { Allbutonerequired } \\
\text { element for the individual } \\
\text { project choice are present. }\end{array}$ & $\begin{array}{l}\text { More than one required } \\
\text { element for the individual } \\
\text { project choice are present. }\end{array}$ \\
\hline $\begin{array}{l}\text { PRESENTATION } \\
\text { QUALITY OF } \\
\text { WORK } \\
\end{array}$ & $\begin{array}{l}\text { The project is not only neat } \\
\text { and readable, but also } \\
\text { details that make it } \\
\text { extremely visually } \\
\text { appealing and viewer }\end{array}$ & $\begin{array}{l}\text { The project is neat and } \\
\text { readable. }\end{array}$ & $\begin{array}{l}\text { The project is readable, } \\
\text { but some parts are not } \\
\text { neat. }\end{array}$ & $\begin{array}{l}\text { The project has many } \\
\text { aspects that make it messy } \\
\text { and hard to read. }\end{array}$ \\
\hline $\begin{array}{l}\text { VOICE- } \\
\text { ORIGINALITY } \\
\text { OF THOUGHTS }\end{array}$ & $\begin{array}{l}\text { The project is reflective } \\
\text { of the student's } \\
\text { individual style and } \\
\text { ideas. The only thing it } \\
\text { shares with the video or } \\
\text { textbook is the fact that it } \\
\text { is on the same topic with } \\
\text { the same information. }\end{array}$ & $\begin{array}{l}\text { The project is presented } \\
\text { in a way that is not } \\
\text { identical to either the } \\
\text { video or the textbook. } \\
\text { it }\end{array}$ & $\begin{array}{l}\text { 1-2 parts of the project are } \\
\text { extremely similar to the } \\
\text { video or textbook. }\end{array}$ & $\begin{array}{l}\text { The project seems to be } \\
\text { copied almost word for } \\
\text { word and picture for } \\
\text { picture from the video or } \\
\text { textbook. }\end{array}$ \\
\hline
\end{tabular}


Responding to Literature Rubric for $6^{\text {th }}$ GradeELA

(Aligned with Common CoreStandards)-August 2013

\begin{tabular}{|c|c|c|c|c|c|}
\hline \multicolumn{2}{|c|}{$\begin{array}{l}\text { Criteria for } \\
6^{\text {th }} \text { Grade }\end{array}$} & \begin{tabular}{|l} 
Excee \\
ds \\
(Above \\
Grade Level)
\end{tabular} & $\begin{array}{l}\text { Proficient/Meets } \\
\text { (On Grade Level) }\end{array}$ & \begin{tabular}{|l} 
Basic \\
(Approaching \\
Grade Level)
\end{tabular} & \begin{tabular}{|l|} 
Below \\
Basic \\
(Below \\
Grade \\
Level) \\
\end{tabular} \\
\hline \multirow{3}{*}{ 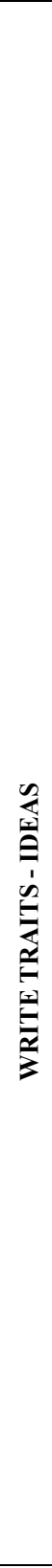 } & $\begin{array}{l}\text { Focus/ } \\
\text { Opinio } \\
\text { n } \\
\text { CCSS: } \\
\text { W.6.1 } \\
\text { W.6.4 } \\
\text { (CLAIM) }\end{array}$ & $\begin{array}{l}\text { Responds } \\
\text { skillfully to all } \\
\text { aspects of the prompt } \\
\text { - Introduces a } \\
\text { claim/thesis that } \\
\text { demonstrates an } \\
\text { insightful } \\
\text { understanding of a } \\
\text { literary work (e.g., } \\
\text { theme, character } \\
\text { development, } \\
\text { structures of a story) } \\
\text { - The development, } \\
\text { organization, and style } \\
\text { skillfully account for } \\
\text { task, purpose, and } \\
\text { audience }\end{array}$ & $\begin{array}{l}\text { Responds to all aspects of } \\
\text { the prompt } \\
\text { - Introduces a claim/thesis } \\
\text { that demonstrates an } \\
\text { understanding of a literary } \\
\text { work (e.g., theme, character } \\
\text { development, structures of a } \\
\text { story) } \\
\text { - The development, } \\
\text { organization and style are } \\
\text { appropriate to task, purpose, } \\
\text { and audience. }\end{array}$ & $\begin{array}{l}\text { - Responds to most, but not al } \\
\text { aspects of the prompt } \\
\text { - Introduces a partial } \\
\text { claim/thesis that demonstrates a } \\
\text { limited understanding of a } \\
\text { literary work (e.g., theme, } \\
\text { character development, } \\
\text { structures of a story) } \\
\text { - The development } \\
\text { organization and style are } \\
\text { inconsistent with task, purpose, } \\
\text { and/or audience. }\end{array}$ & $\begin{array}{l}\text { - Does not respond } \\
\text { to the prompt } \\
\text { - Does not state } \\
\text { a claim/thesis } \\
\text { that } \\
\text { demonstrates an } \\
\text { understanding } \\
\text { of a literary } \\
\text { work (e.g., } \\
\text { theme, character } \\
\text { development, } \\
\text { structures of a } \\
\text { story) } \\
\text { - The } \\
\text { development, } \\
\text { organization and } \\
\text { style are not } \\
\text { appropriate } \\
\text { for the task, } \\
\text { purpose, and/or } \\
\text { audience }\end{array}$ \\
\hline & $\begin{array}{l}\text { Evidence } \\
\text { /Support } \\
\text { CCSS: } \\
\text { W.6.1 } \\
\text { W.6.9 } \\
\text { RL.6.1 } \\
\text { (EVIDENCE) }\end{array}$ & $\begin{array}{l}\text { Provides } \\
\text { sufficient and } \\
\text { relevant evidence } \\
\text { to support } \\
\text { response } \\
\text { - Competently } \\
\text { integrates and cites } \\
\text { textual evidence } \\
\text { (paraphrasing, } \\
\text { summarizing and } \\
\text { quoting) }\end{array}$ & $\begin{array}{l}\text { Supplies relevant } \\
\text { evidence to support response } \\
\text { - Cites textual evidence } \\
\text { (paraphrasing, summarizing } \\
\text { and quoting) to support } \\
\text { analysis }\end{array}$ & $\begin{array}{l}\text { Provides little evidence } \\
\text { to support response } \\
\text { - Cites little textual } \\
\text { evidence to support analysis }\end{array}$ & $\begin{array}{l}\text { - Provides } \\
\text { inaccurate or no } \\
\text { evidence to } \\
\text { support response } \\
\text { - Does not use } \\
\text { or cite sources } \\
\text { and/or textual } \\
\text { evidence }\end{array}$ \\
\hline & $\begin{array}{l}\text { Analysi } \\
\text { s } \\
\text { CCSS: } \\
\text { W.6.1 } \\
\text { W.6.9 } \\
\text { (REASONING) }\end{array}$ & $\begin{array}{l}\text { Shows an insightful } \\
\text { understanding of key } \\
\text { ideas } \\
\text { - Uses logical and } \\
\text { sophisticated } \\
\text { reasoning to connect } \\
\text { evidence with } \\
\text { claim(s) } \\
\text { - Shows an insightful } \\
\text { understanding of how } \\
\text { author's choices affect } \\
\text { meaning }\end{array}$ & $\begin{array}{l}\text { Shoes a thorough } \\
\text { understanding of key ideas } \\
\text { - Uses logical and } \\
\text { accurate reasoning to } \\
\text { connect evidence with } \\
\text { claim(s) } \\
\text { - Shows an understanding } \\
\text { of how author's choices } \\
\text { affect meaning }\end{array}$ & $\begin{array}{l}\text { - Shows limited } \\
\text { understanding of key ideas } \\
\text { - Uses some logical and } \\
\text { accurate reasoning to } \\
\text { connect evidence with } \\
\text { claim(s) } \\
\text { - Shows limited } \\
\text { understanding of how } \\
\text { author's choices affect } \\
\text { meaning }\end{array}$ & $\begin{array}{l}\text { - Does not } \\
\text { show an } \\
\text { understanding } \\
\text { of key ideas } \\
\text { - Reasoning is } \\
\text { missing or does } \\
\text { not connect } \\
\text { evidence with } \\
\text { claim(s) } \\
\text { - Does not show } \\
\text { an understanding } \\
\text { of how author's } \\
\text { choices affect } \\
\text { meaning }\end{array}$ \\
\hline
\end{tabular}




\begin{tabular}{|c|c|c|c|c|c|}
\hline 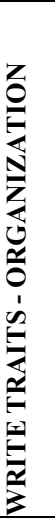 & $\begin{array}{l}\text { Structure } \\
\text { /Cohesio } \\
\text { n CCSS: } \\
\text { W.6.1 } \\
\text { (ORGANIZATION } \\
\text { TRANSITIONS) }\end{array}$ & $\begin{array}{l}\text { - Organizes } \\
\text { essay logically by } \\
\text { establishing } \\
\text { relationships } \\
\text { among claim(s), } \\
\text { reasons, and } \\
\text { evidence } \\
\text { - Creates cohesion } \\
\text { through a skillful use } \\
\text { of transition/linking } \\
\text { words, phrases, and } \\
\text { clauses } \\
\text { - Provides a } \\
\text { conclusion that } \\
\text { follows from and } \\
\text { supports claim(s) }\end{array}$ & $\begin{array}{l}\text { Organizes the reasons and } \\
\text { relevant evidence clearly } \\
\text { - Uses words, phrases, and } \\
\text { clauses to clarify the } \\
\text { relationship among claim(s) } \\
\text { and reasons } \\
\text { - Provides a concluding } \\
\text { statement or section that } \\
\text { follows from the response } \\
\text { presented }\end{array}$ & $\begin{array}{l}\text { Partially organizes the } \\
\text { reasons and relevant evidence } \\
\text { - Uses some words, phrases, } \\
\text { and clauses to clarify the } \\
\text { relationship among claim(s) } \\
\text { and reasons } \\
\text { - Provides a concluding } \\
\text { statement or section }\end{array}$ & $\begin{array}{l}\text { - Organizes } \\
\text { essay with } \\
\text { significant errors } \\
\text { in sequence } \\
\text { - Uses few or no } \\
\text { transition/ linking } \\
\text { words, phrases, or } \\
\text { clauses to connect } \\
\text { claim(s) and } \\
\text { reasons } \\
\text { - Omits conclusion }\end{array}$ \\
\hline 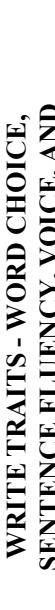 & $\begin{array}{l}\text { Language Usage/ } \\
\text { Voice } \\
\text { CCSS } \\
\text { L.6.1 } \\
\text { L. } 6.2 \\
\text { L.6.3 } \\
\text { W.6.1 } \\
\text { W.6.4 } \\
\\
\\
\\
\end{array}$ & $\begin{array}{l}\text { Uses correct } \\
\text { sentence structure and } \\
\text { varies sentence patterns } \\
\text { for meaning, interest, } \\
\text { and style } \\
\text { - Skillful use of } \\
\text { conventions } \\
\text { - Establishes and } \\
\text { maintains a formal } \\
\text { style and objective } \\
\text { tone } \\
\text { - Uses } \\
\text { precise and } \\
\text { audience- } \\
\text { appropriate } \\
\text { word choice } \\
\text { - Competently } \\
\text { cites evidences using } \\
\text { correct MLA format }\end{array}$ & $\begin{array}{l}\text { - Contains few errors in } \\
\text { sentence structure and varies } \\
\text { sentence patterns for meaning, } \\
\text { interest, and style } \\
\text { - Contains few, minor errors } \\
\text { in conventions without causing } \\
\text { confusion } \\
\text { - Establishes and } \\
\text { maintains a formal style } \\
\text { - Uses appropriate word } \\
\text { choice } \\
\text { - Cites evidence using } \\
\text { the correct MLA format }\end{array}$ & $\begin{array}{l}\text { - Contains some errors in } \\
\text { sentence structure and does not } \\
\text { vary sentence patterns for } \\
\text { meaning, interest, and style } \\
\text { - Demonstrates use of some } \\
\text { grade level appropriate } \\
\text { conventions, but errors obscure } \\
\text { meaning } \\
\text { - Uses inconsistent style } \\
\text { (voice) or uses both formal } \\
\text { and informal styles } \\
\text { - Uses vague or basic } \\
\text { word choice } \\
\text { - Attempts to cite } \\
\text { evidence with MLA format }\end{array}$ & $\begin{array}{l}\text { - Lacks sentence } \\
\text { mastery (e.g., } \\
\text { fragments/ run- } \\
\text { ons) } \\
\text { - Contains serious } \\
\text { and pervasive } \\
\text { errors in } \\
\text { conventions } \\
\text { - Uses and } \\
\text { inappropriate } \\
\text { style and tone } \\
\text { for the prompt } \\
\text { - Uses limited or } \\
\text { incorrect word } \\
\text { choice } \\
\text { - Does not cite } \\
\text { evidence with } \\
\text { MLA format }\end{array}$ \\
\hline
\end{tabular}

Responding to Literature Rubric for $6^{\text {th }}$ Grade ELA (Aligned with Common Core standards).August 2013SCORING NOTE: Teachers should consider the preponderance of evidence from student work when determining overall performance level. Students should also have multiple opportunities to work with the rubric, review exemplars, and revise/modify their work prior to any summative use of this rubric.

\begin{tabular}{|l|l|l|l|}
\hline Strand & Fifth Grade & Sixth Grade & Seventh Grade \\
\hline $\begin{array}{l}\text { Reading } \\
\text { Literature }\end{array}$ & $\begin{array}{l}\text { RL.5.1: Quote accurately from a } \\
\text { text when explaining what the text } \\
\text { says explicitly and when drawing } \\
\text { inferences from the text. }\end{array}$ & $\begin{array}{l}\text { RL.6.1: Cite textual evidence } \\
\text { (paraphrase, summarize, quote) } \\
\text { using MLA format to support } \\
\text { analysis of what the text says } \\
\text { explicitly as well as inferences drawn } \\
\text { from the text. }\end{array}$ & $\begin{array}{l}\text { RL.7.1: Cite several pieces of textual } \\
\text { evidence (paraphrase, summarize, quote) } \\
\text { using MLA format to support analysis of } \\
\text { what the text says explicitly as well as } \\
\text { inferences drawn from the text. }\end{array}$ \\
\hline
\end{tabular}




\begin{tabular}{|c|c|c|c|}
\hline Writing & $\begin{array}{l}\text { W.5.1: Write opinion pieces on } \\
\text { topics or texts, supporting a } \\
\text { point of view with } \\
\text { reasons and inform } \\
\text {-ation. } \\
\text { a. Introduce a topic or text clearly, } \\
\text { state an opinion, and } \\
\text { create an organizational structure in } \\
\text { which ideas are logically grouped } \\
\text { to support the writer's purpose. } \\
\text { b. Provide logically ordered } \\
\text { reasons that are supported by } \\
\text { facts and details. } \\
\text { c. Link opinion and reasons using } \\
\text { words, phrases, and clauses (e.g., } \\
\text { consequently, specifically). } \\
\text { d. Provide a concluding statement } \\
\text { or section related to } \\
\text { the opinion presented. } \\
\text { W.5.4: Produce clear and coherent } \\
\text { writing (including multi- paragraph } \\
\text { texts) in which the development } \\
\text { and organization are appropriate to } \\
\text { task, purpose, and audience. } \\
\text { W.5.9: Draw evidence from literary } \\
\text { or informational texts to support } \\
\text { analysis, reflection, and research. }\end{array}$ & $\begin{array}{l}\text { W.6.1: Write arguments to support } \\
\text { claims with clear } \\
\text { reasons and relevant evidence. } \\
\text { a. Introduce claim(s) and organize the } \\
\text { reasons and evidence clearly. } \\
\text { b. Support claim(s) with clear } \\
\text { reasons and relevant evidence, } \\
\text { using credible sources and } \\
\text { demonstrating an understanding of } \\
\text { the topic or text. } \\
\text { c. Use words, phrases, and } \\
\text { clauses to clarify the } \\
\text { relationships among claims(s) } \\
\text { and reasons. } \\
\text { d. Establish and maintain a formal } \\
\text { style. } \\
\text { e. Provide a concluding } \\
\text { statement or section that follows } \\
\text { from the argument presented. } \\
\text { W.6.4: Produce clear and coherent } \\
\text { writing in which the } \\
\text { development, organization, and } \\
\text { style are appropriate to task, } \\
\text { purpose and audience. } \\
\text { W6..9: Draw evidence from literary } \\
\text { or informational } \\
\text { texts to support analysis, reflection, } \\
\text { and research. }\end{array}$ & $\begin{array}{l}\text { W.7.1: Write arguments to support claims with } \\
\text { clear reasons and } \\
\text { relevant evidence. } \\
\text { a. Introduce claim(s), acknowledge alternate or } \\
\text { opposing } \\
\text { claims, and organize the reasons and evidence } \\
\text { logically. b. Support claim(s) with logical } \\
\text { reasoning and relevant } \\
\text { evidence, using accurate, credible } \\
\text { sources and demonstrating an } \\
\text { understanding of the topic or text. } \\
\text { c. Use words, phrases, and clauses to create } \\
\text { cohesion and clarify the relationships } \\
\text { among claims(s), reasons, and evidence. } \\
\text { d. Establish and maintain a formal style. } \\
\text { e. Provide a concluding statement or } \\
\text { section that follows from the argument } \\
\text { presented. } \\
\text { W.7.4: Produce clear and coherent writing in } \\
\text { which the } \\
\text { development, organization, and style } \\
\text { are appropriate to task, purpose and } \\
\text { audience. } \\
\text { W.7.9: Draw evidence from literary or } \\
\text { informational texts to } \\
\text { support analysis, reflection, and research. }\end{array}$ \\
\hline Language & $\begin{array}{l}\text { L.5.1: Demonstrate command of the } \\
\text { conventions of standard } \\
\text { English grammar and usage when } \\
\text { writing or speaking. } \\
\text { L.5.2: Demonstrate command of the } \\
\text { conventions of standard English } \\
\text { capitalization, punctuation, and } \\
\text { spelling when writing (items in a } \\
\text { series, direct address, titles of } \\
\text { works). L.5.3: Use knowledge of } \\
\text { language and its conventions when } \\
\text { writing, speaking, reading, or } \\
\text { listening. } \\
\text { a. Expand, combine, and } \\
\text { reduce sentences for } \\
\text { meaning, reader/listener } \\
\text { interest, and style. } \\
\text { b. Compare and contrast the varieties } \\
\text { of English (e.g., dialects, registers) } \\
\text { used in stories, dramas, or } \\
\text { poems }\end{array}$ & $\begin{array}{l}\text { L.6.1: Demonstrate command of the } \\
\text { conventions of } \\
\text { standard English grammar and } \\
\text { usage when writing or speaking. } \\
\text { L.6.2: Demonstrate command of } \\
\text { the conventions of standard } \\
\text { English capitalization, punctuation, } \\
\text { and spelling when writing (use } \\
\text { commas, parentheses, and dashes } \\
\text { to set off } \\
\text { nonrestrictive/parenthetical } \\
\text { elements). L.6.3: Use knowledge of } \\
\text { language and its conventions when } \\
\text { writing, speaking, reading, or } \\
\text { listening. } \\
\text { a. Vary sentence patterns } \\
\text { for meaning, } \\
\text { reader/listener } \\
\text { interest, and style } \\
\text { b. Maintain consistency in } \\
\text { style and tone }\end{array}$ & $\begin{array}{l}\text { L.7.1: Demonstrate command of the conventions } \\
\text { of standard } \\
\text { English grammar and usage when writing or } \\
\text { speaking. } \\
\text { L.7.2: Demonstrate command of the } \\
\text { conventions of standard English } \\
\text { capitalization, punctuation, and spelling } \\
\text { when writing (commas to separate } \\
\text { coordinate adjectives). } \\
\text { L.7.3: Use knowledge of language and } \\
\text { its conventions when writing, speaking, } \\
\text { reading, or listening. } \\
\text { a. Choose language that expresses ideas } \\
\text { precisely and concisely, recognizing and } \\
\text { eliminating wordiness and redundancy. }\end{array}$ \\
\hline
\end{tabular}


NOTES: In the left criterion boxes of the rubric, the CCSS-aligned standards have been identified. As a resource for teachers, below are the standards for the current grade (6) as well as the subsequent grade. Since the rubric score of "4" represents "above grade level" work, the 7 th grade standards were referenced. The letter abbreviations are as follows: $\mathrm{CCSS}=$ Common Core State Standard $\mathrm{W}=$ Writing RI $=$ Reading Informational Text $\mathrm{L}=$ Language

PROMPTS TAKEN FROM THE 6th GRADE READING LITERATURE STANDARDS:

- RL.6.2: Determine a theme or central idea of a text and how it is conveyed through particular details; provide a summary of the text distinct from personal opinions or judgments.

- RL.6.3: Describe how a particular story's or drama's plot unfolds in a series of episodes as well as how the characters respond or change as the plot moves toward a resolution.

- RL.6.5: Analyze how a particular sentence, chapter, scene, or stanza fits into the overall structure of a text and contributes to the development of the theme, setting, or plot.

- RL.6.9: Compare and contrast the treatment of similar themes and topics and patterns of events in stories, myths, and traditional literature from different cultures. 
Name:

\section{Map Making Project}

Assignment: Using the whitedrawing paper that l've given you, draw a map. You can choose to make a map of:

1 a store

2. a restaurant

3. a zoo

4. a mall

5. a recreation center

6. Other: If you'd like to make a map of something else, please talk to me about it first, to get my approval.

Map Requirements include:

- A name/title for the map you choose to make.

- The name/title must be easily seen on your map.

- Draw at least 10 different things that can be found at the place that you choose (store, restaurant, zoo, mall, or recreation center.) If you want to draw more than 10 things, that is just fine!

- Make a Map Key with symbols that represent what you drew on your map. Youcan draw the Map Key on your map, or a separate piece of paper.

- Draw a compass rose that can easily be seen on your map.

- Write your name and number on the back of the map.

- The background of your map must be shaded in.

- Useonly crayons or colored pencils. Youmay use a thin black marker if you choose to outline or label items onyour map.

A rubric has been given to you so that you know what you need to do to get the grade that you want. I will be using this rubri to grade your Map Making Project. I can't wait to see your wonderfulmaps!

\section{Due date is Monday, January 19.}




\section{Map Making Rubric}

Name:

\#:

Teacher:

Date:

Title of Work:

\begin{tabular}{|l|l|l|l|l|l|}
\hline & & & & & Points \\
\hline & 1 & 2 & 3 & 4 & \\
\hline $\begin{array}{l}\text { Map } \\
\text { Require- } \\
\text { ments }\end{array}$ & $\begin{array}{l}\text { Evidence of 2 } \\
\text { or less map } \\
\text { requirements }\end{array}$ & $\begin{array}{l}\text { Evidence of 3 } \\
\text { map require- } \\
\text { ments }\end{array}$ & $\begin{array}{l}\text { Evidence of 4- } \\
6 \text { map require- } \\
\text { ments }\end{array}$ & $\begin{array}{l}\text { Evidence of ALL } \\
\text { map requirements }\end{array}$ & \\
\hline Spelling & $\begin{array}{l}5 \text { or more } \\
\text { spelling errors }\end{array}$ & $\begin{array}{l}4 \text { spelling er- } \\
\text { rors }\end{array}$ & $\begin{array}{l}2-3 \text { spelling } \\
\text { errors }\end{array}$ & $0-1$ spelling errors & \\
\hline Neatness & $\begin{array}{l}\text { Poor } \\
\text { coloring - } \\
\text { poor printing/ }\end{array}$ & $\begin{array}{l}\text { Satisfactory } \\
\text { coloring } \\
\text { Satisfactory } \\
\text { printing/ } \\
\text { labeling }\end{array}$ & $\begin{array}{l}\text { Good coloring } \\
\text { Good printing/ } \\
\text { labeling }\end{array}$ & $\begin{array}{l}\text { Exceptional color- } \\
\text { ing } \\
\text { Exceptional print- } \\
\text { ing/ } \\
\text { labeling }\end{array}$ & \\
\hline & & \multicolumn{5}{l|l}{} & Total & \\
\hline
\end{tabular}

Teacher Comments: 


\section{Write Traits 4 Point Rubric -}

General Response to Literature

\begin{tabular}{|c|c|c|c|c|}
\hline & $\begin{array}{l}\text { 4- Exceeds } \\
\text { Standards }\end{array}$ & $\begin{array}{l}\text { 3- Meets } \\
\text { Standards }\end{array}$ & $\begin{array}{l}\text { 2- Approaching } \\
\text { Standards }\end{array}$ & $\begin{array}{l}\text { 4-Below } \\
\text { Standards }\end{array}$ \\
\hline Ideas & $\begin{array}{l}\text { - Writer } \\
\text { focuses on one } \\
\text { main idea or } \\
\text { claim that } \\
\text { responds to the } \\
\text { prompt. } \\
\text { - Writer uses } \\
\text { more than } 3 \\
\text { appropriate } \\
\text { textual pieces of } \\
\text { evidence to } \\
\text { support their } \\
\text { main idea or } \\
\text { claim. }\end{array}$ & $\begin{array}{l}\text { - Writer focuses } \\
\text { on one main } \\
\text { idea or claim } \\
\text { that responds to } \\
\text { the prompt. } \\
\text { - Writer uses at } \\
\text { least } 3 \text { appropriate } \\
\text { textual pieces of } \\
\text { evidence to } \\
\text { support their main } \\
\text { idea or claim. }\end{array}$ & $\begin{array}{l}\text { - Writer's } \\
\text { main idea is } \\
\text { unclear or } \\
\text { unrelated to the } \\
\text { prompt. } \\
\text { - Writer uses } 1 \text { - } 2 \\
\text { appropriate textual } \\
\text { pieces of evidence } \\
\text { to support their } \\
\text { main idea or claim. }\end{array}$ & $\begin{array}{l}\text { - Writer's main } \\
\text { idea is unclear and } \\
\text { unrelated to the } \\
\text { prompt. } \\
\text { - Writer uses no } \\
\text { appropriate textual } \\
\text { evidence to support } \\
\text { their main idea or } \\
\text { claim. }\end{array}$ \\
\hline Organization & $\begin{array}{l}\text { - Writer } \\
\text { includes an } \\
\text { attention } \\
\text { grabbing } \\
\text { topic } \\
\text { sentence. } \\
\text { - Writer includes } \\
\text { a concluding } \\
\text { sentence that } \\
\text { sums up the } \\
\text { paragraph in a } \\
\text { new and } \\
\text { interesting way. } \\
\text { - Transitions } \\
\text { are used to } \\
\text { connect all } \\
\text { ideas. }\end{array}$ & $\begin{array}{l}\text { - Writer } \\
\text { includes a } \\
\text { topic } \\
\text { sentence. } \\
\text { - Writer includes } \\
\text { a concluding } \\
\text { sentence that } \\
\text { sums up the } \\
\text { paragraph. } \\
\text { - Transitions } \\
\text { are sometimes } \\
\text { used to } \\
\text { connect ideas. }\end{array}$ & $\begin{array}{l}\text { - Writer } \\
\text { includes a } \\
\text { topic sentence. } \\
\text { - Writer includes a } \\
\text { clear concluding } \\
\text { sentence. }\end{array}$ & $\begin{array}{l}\text { - Writer is missing } \\
\text { a topic sentence, } \\
\text { concluding sentence } \\
\text { or both. }\end{array}$ \\
\hline Voice & $\begin{array}{l}\text { Writer clearly } \\
\text { expresses his or } \\
\text { her thoughts in a } \\
\text { way that is } \\
\text { personally } \\
\text { identifiable. }\end{array}$ & $\begin{array}{l}\text { - Writer clearly } \\
\text { expresses his or } \\
\text { her thoughts in a } \\
\text { consistent way. }\end{array}$ & $\begin{array}{l}\text { - Writer clearly } \\
\text { expresses his or } \\
\text { her thoughts. }\end{array}$ & $\begin{array}{l}\text { - It is difficult to } \\
\text { understand the } \\
\text { writer's thoughts. }\end{array}$ \\
\hline Word Choice & $\begin{array}{l}\text { - Writer uses a } \\
\text { variety of } \\
\text { descriptors that } \\
\text { paints a clear } \\
\text { picture for the } \\
\text { reader. } \\
\text { - Writer rarely } \\
\text { reuses } \\
\text { similar } \\
\text { descriptors. }\end{array}$ & $\begin{array}{l}\text { - Writer uses a } \\
\text { variety of } \\
\text { descriptors that } \\
\text { paints a clear } \\
\text { picture for the } \\
\text { reader. }\end{array}$ & $\begin{array}{l}\text { - Writer uses few } \\
\text { varying descriptors } \\
\text { that sometimes } \\
\text { help the reader } \\
\text { understand. }\end{array}$ & $\begin{array}{l}\text { - Writer uses simple } \\
\text { words that do not } \\
\text { help the reader } \\
\text { understand. }\end{array}$ \\
\hline $\begin{array}{l}\text { Sentence } \\
\text { Fluency }\end{array}$ & $\begin{array}{l}\text { - Writer uses a } \\
\text { variety of } \\
\text { sentence lengths } \\
\text { and phrases. } \\
\text { - Sentences } \\
\text { never begin in } \\
\text { the same way }\end{array}$ & $\begin{array}{l}\text { - Writer uses a } \\
\text { variety of sentence } \\
\text { lengths and } \\
\text { phrases. } \\
\text { - Sentences rarely } \\
\text { begin in the same } \\
\text { way }\end{array}$ & $\begin{array}{l}\text { - Within a } 5 \text { - } \\
\text { sentence } \\
\text { paragraph, } 2 \\
\text { sentences begin } \\
\text { the same way }\end{array}$ & $\begin{array}{l}\text { - Within a } 5 \text { - } \\
\text { sentence } \\
\text { paragraph, more } \\
\text { than } 2 \text { sentences } \\
\text { begin the same } \\
\text { way. }\end{array}$ \\
\hline
\end{tabular}


[Vol. 41:713

\begin{tabular}{|c|c|c|c|c|}
\hline Conventions & $\begin{array}{l}\text { - Paper is free } \\
\text { of grammatical } \\
\text { and/or spelling } \\
\text { errors. }\end{array}$ & $\begin{array}{l}- \text { Paper has less } \\
\text { than } \\
3 \text { grammatical } \\
\text { and/or spelling } \\
\text { errors. }\end{array}$ & $\begin{array}{l}\text { - Paper has 4-6 } \\
\text { grammatical } \\
\text { and/or spelling } \\
\text { errors. }\end{array}$ & $\begin{array}{l}\text { - Paper has more } \\
\text { than } 6 \text { grammatical } \\
\text { and/or spelling } \\
\text { errors. } \\
\text { - Errors distract } \\
\text { from the reader's } \\
\text { understanding. }\end{array}$ \\
\hline
\end{tabular}




\title{
Appendix 3
}

\author{
Trial Brief I \\ 35 points \\ Spring 2009
}

COURT AND PARTY INFORMATION: 1 point

$\underline{\text { Caption and title }}$

Correctly identifies the court

Correctly formats information

Correctly identifies all pertinent parties

Corectly identifies judge and docket

number

Correctly identifies document $\underline{\text { Introductory paragraph }}$

Correctly identifies the moving party Briefly states procedural history

States purpose of document

\section{STATEMENT OF FACTS: 3 points}

Begins with introductory sentence identifying parties and nature of dispute.

Uses effective organizational scheme.

Includes all legally relevant facts.

Includes appropriate emotional facts

Includes enough background facts so person unfamiliar with case can

understand what happened.

Identifies any relevant, unknown facts.

Minimizes damaging facts.

Presents facts persuasively and accurately.

Excludes legal conclusions.

Excludes argument.

Includes citation to record, excludes citations to authority.

Tells persuasive story, the way client wants judge to see what happened. 


\section{ARGUEMNT: 21 points}

\section{Organization: 2 points}

Begins with thesis paragraph announcing ultimate contention.

Includes roadmap that lists main contentions, including the applicable

procedural standard for desired relief.

Signals discussion of main contention with point heading.

In each main contention, states the general rule.

Develops rule to extent necessary or appropriate, moving from general

rules to more specific rules.

Signals discussion of sub argument with persuasive pint heading announcing sub-contention.

Illustrates (explains) precedent in appropriate order.

Illustrates (explains) precedent before applying it to client's facts.

\section{Persuasive rules and persuasive illustrations: 3 points}

Presents rules from client's perspective.

Uses language of law without lapsing into legalese.

Uses directions/topic sentence at the start of each paragraph to introduce each illustration/explanation/application.

Provides all outcome-determinative facts, and only outcomedeterminative facts.

States court's holding. Properly differentiating between use of "held," "found,"“ruled,"etc.

Articulates court's and other authority's reasoning.

Refers to parties by descriptive terms that the law imposes on parties, rather than by name.

Explains precedent accurately and also the way advocate wants court to understand those precedents. 


\section{Persuasive Applications: 10 points}

Signals application of each case or authority by thesis sentence

announcing whether case is mandatory or not and rule to be applied.

Provides fact-to-fact comparisons, explaining why facts are similar or different, if not obvious.

Articulates legal significance of that similarity or difference.

Does not substitute court's holding and/or reasoning for that legal significance.

Urges judge to apply or extend favorable rule and/or precedent.

Raises and reconciles mandatory adverse authority.

Makes relevant policy arguments.

\section{Research: 6 points}

Provides research log showing research path, research results, and that case/statute was shephardized.

Chooses among cases and other authority sensibly.

Interprets authority rationally and accurately.

\section{CONCLUSION: .5 point}

Clearly and briefly states relief requested.

\section{CITATION: 2 points}

Attributes all rules and non-original ideas to their sources.

Citations conform to the Bluepages of The Bluebook.

Places citations to maximize flow of information (citation sentences

preferred to citation clauses, citation moved to end of sentence when case name is mentioned textually).

Uses short cites correctly. 


\section{WRITING}

\section{Point headings: 3 points}

Organization and arguments are clear through the use of persuasive point headings.

Point headings announce legal conclusions advocate hopes court will adopt, rather than statement of rule.

\section{General writing: 3 points}

A judge can understand the Trial Brief after reading it once.

Paragraph divisions are logical, and paragraph lengths are appropriate.

In most sentences, actor is subject, and subject are verb are close

together.

Varies sentence lengths and patters, and each sentence flows smoothly from prior sentence.

Uses past tense to describe past events.

Writing is concise, precise, and uses plain language.

Grammar and punctuation are correct.

Spelling and word choice are accurate.

Refrains from first-person or second-person usage.

Uses passive voice appropriately.

Uses language of persuasion.

Keeps focus on client by explaining what client is entitled to, not what opponent is not entitled to.

Uses affirmative, rather than negative language.

\section{PROFESSIONALISM}

\section{Proper form: 1 point}

Follows general instructions for assignment.

Uses 12-point font. 
Single- and double- spaces appropriately.

Uses left-hand justification.

Numbers pages appropriately.

Uses one-inch margins.

Document's general appearance is professional (not smudged, wrinkled, sloppily stapled, etc).

Document shows evidence of proofreading.

\section{Signature block: .5 point}

Signed by advocate

Dated

Includes advocate's address and other identifying information

\section{Additional comments:}

Score: 